\title{
A new 'microstructural mapping' methodology for the identification, analysis and interpretation of polyphase deformation within subglacial sediments
}

Emrys Phillips ${ }^{1 *}$, Jaap J.M. van der Meer ${ }^{2}$ and Amanda Ferguson ${ }^{2}$

1. British Geological Survey, Murchison House, West Mains Road, Edinburgh EH9 3LA, UK

2. School of Geography, Queen Mary, University of London, Mile End Road, London E1 4NS, UK

* Corresponding author. telephone: 0131-667-1000. fax: 0131-668-2683. e-mail: erp@bgs.ac.uk

\begin{abstract}
Although integrated clast macro- and microfabric studies have been used to provide evidence of palaeo-ice flow directions, to discriminate between diamictons deposited in differing sedimentary environments, and to model the response of tills to subglacial deformation, such studies have typically only examined the 'bulk' fabric developed within the diamicton, largely ignoring the potential for several phases of fabric development within these typically polydeformed deposits. We present a new graphical method for the identification, description and analysis of clast microfabrics in polydeformed tills. This method utilises high resolution digital scans of orientated thin sections imported into a standard computer graphics package to measure the orientation of long axes of detrital (skeleton) grains included within the till. These data are then used to identify the main clast microfabrics present within the till, allowing the delineation of clast microfabric domains in which elongate grains share a similar preferred orientation. This process leads to the identification, characterisation and, most importantly, the interrelationships between the various generations of microfabrics. The relationships between these clast microfabrics and other microstructures (e.g. plasmic fabrics, turbate structures, shears, folds, faults...etc) can also be examined, providing a detailed microfabric-microstructural map of the thin section. Clast long axis orientation data collected for different parts of a thin section are plotted on a series of rose diagrams allowing the variation in clast microfabric orientation to be displayed graphically. A new set of terminology for the description of clast microfabrics in tills, which is based upon the system used by metamorphic petrologists, is also presented. Three case studies of the fabrics present within subglacial sediments of Pleistocene age as well as the present are used as examples of how to apply this methodology.
\end{abstract}

\section{Introduction}

Micromorphology is increasingly being used by glaciologists and Quaternary geologists as a primary tool for the analysis of diamictons deposited in different sedimentary environments (van der Meer 1987; Harris 1998; Lachniet et al., 1999; Carr et al., 2000; Carr 2001; Lachniet et al., 2001; Menzies and Zaniewski 2003; Carr et al., 2006; Phillips 2006; Menzies et al., 2006; Reinardy and Lukas 2009; Kilfeather et al., 2010), as an aid to understanding the processes occurring beneath glaciers (Menzies and Maltman 1992; van der Meer 1997; Menzies et al., 1997; Khatwa and Tulaczyk 2001; van der Meer et al., 2003; Roberts and Hart 2005; Hiemstra et al., 2005; Baroni and Fasano 2006; Larsen et al., 2006; Hart 2007; Larsen et al., 2007), to 
help unravel the often complex deformation histories recorded by glacigenic sequences (van der Meer 1993; Phillips and Auton 2000; van der Wateren et al., 2000; Menzies 2000; Phillips et al., 2007; Lee and Phillips 2008; Denis et al., 2010), and investigate the role played by pressurised pore-water/melt water during these deformation events (Hiemstra and van der Meer 1997; Phillips and Merritt 2008; van der Meer et al., 2009; Denis et al., 2010). In the majority of these published studies the terminology used to describe the various microtextures in thin section follows that proposed by van der Meer (1987, 1993) and Menzies (2000). Although a powerful tool in the glacial scientists armoury in the study of both modern and ancient glacigenic sedimentary sequences, micromorphological studies should not be used in isolation, but as part of a multidisciplinary approach, involving sedimentological, geomorphological and structural field techniques. It is critical that correctly orientated samples are collected for thin sectioning so that kinematic indicators (such as asymmetrical folds, faults, SC-fabrics...etc; see Passchier and Trouw 1996) can be correctly used to provide information on the stress regime active during deformation and local ice movement directions. The orientation of the samples, relative to the presumed directions of ice advance and retreat needs to be established as only samples orientated parallel to the principal direction of ice movement will exhibit the most complete record of deformation and its intensity.

Subglacial diamictons are typically polydeformed deposits, the so called "tectomict" of Menzies et al. (2006), having encountered several phases of deformation during either a single progressive event associated with a single phase of ice advance, or several multiple deformation events related to separate phases/pulses of ice advance and retreat. In a number of studies of polydeformed glacial sediments (e.g. Phillips and Auton 2000; van der Wateren et al., 2000; Phillips et al., 2007; Denis et al., 2010) the successive generations of plasmic fabrics, folds, rotational structures and faults present in thin section have been distinguished by applying the methodologies and nomenclature normally used in structural geological studies (e.g. F1 earliest folds to Fn latest, S1 earliest fabric to Sn latest). However, a similar approach for the recognition, analysis and interpretation of the interrelationships between the various microstructures developed within diamictons has yet to be established. Published work on systematically recording the type and frequency of microstructures developed within diamictons has largely focused upon attempts to establish their depositional setting (e.g. Carr 2001; Carr et al., 2001; Menzies et al. 2006; Menzies and Whiteman 2009; Kilfeather et al., 2010). The resultant summary tables have been used to compare the range of microfabrics and structures present within diamictons laid down in radically different sedimentary environments. One important drawback to this type of approach is that the relationships between the various microstructures are not recorded. Consequently, such summary tables can not be used as an aid to unravelling the polyphase deformation histories recorded by diamictons and, therefore, do not shed any light on the series of events/processes that led to the formation of these complex deposits. Furthermore, sediment composition (or lithology) can have a profound effect on the range of microstructures developed within a diamicton (e.g. plasmic fabrics will only develop where clay minerals are present within the matrix), potentially leading to the miss identification/characterisation of depositional setting.

Clast microfabric analysis using thin sections of glacial sediments, typically integrated with macrofabric analysis, have been used to provide evidence of palaeo- 
ice flow directions and to model the response of tills to subglacial deformation (Sitler and Chapman 1955; Harrison 1957; Ostry and Deane 1963; Evenson 1970; 1971; Johnson 1983; Carr 1999, 2001; Carr et al., 2000; Lee 2001; Carr and Rose 2003). Work by Carr (2001) has indicated that clasts microfabrics may potentially be used to discriminate between diamictons deposited in differing sedimentary environments (also see Carr 2004). These published studies have typically only examined the "bulk" fabric developed within the diamicton and have largely overlooked the potential presence of several phases of fabric development within these polydeformed deposits. Also the effect of large immobile clasts on the orientation clast microfabrics defined by finer grained detrital components adjacent to these pebbles or boulders (nearest neighbour effects) have not been fully considered in this type of analysis.

In this paper we present a new graphical method for the identification, description and analysis of the range of microstructures and clast microfabrics developed in polydeformed tills. The method utilises high resolution digital scans of orientated thin sections imported into a standard computer graphics package to produce a detailed microstructural 'map' of the thin section. During this process the relationships between successive generations of clast microfabrics and other microstructures (e.g. plasmic fabrics, turbate structures, folds, faults, shears...etc) present within the diamicton are determined, allowing a detailed relative chronology of fabric development to be established, enabling the unravelling of the complex polyphase deformation histories recorded by these deposits. Three case studies are described to highlight the potential of this approach to our understanding of the processes occurring during the deformation of glacial sediments, providing new insights into the processes occurring during glacitectonic deformation.

\section{Methodology for the 'microstructural mapping' and analysis of microfabrics in glacial sediments}

The proposed method utilises high resolution digital scans of orientated thin sections imported into a standard computer graphics package (e.g. CorelDraw) to measure the orientation of long axes of detrital (skeleton) grains included within the diamicton. These data are then used to identify the main clast microfabrics present within the sediment, allowing the delineation of clast microfabric domains in which elongate grains share a similar preferred orientation (Figure 1). This process leads to the identification, characterisation and, most importantly, a greater understanding of the interrelationships between the various generations of microfabrics developed within polydeformed glacial deposits. The relationships between the clast microfabrics and other microstructures (e.g. plasmic fabrics, turbate structures, shears, folds, faults...etc) can also be examined, in conjunction with examination of the thin section under the petrological microscope, to provide a detailed microfabric-microstructural 'map' of the thin section (see Figures 2 and 3). Clast long axis orientation data collected for different parts of a thin section are plotted on a series of rose diagrams allowing the variation in clast microfabric orientation to be displayed graphically.

This relatively simple graphical technique is illustrated in Figure 1 and can be summarised in the following 5 stages:

Stage 1 - import a high resolution scan of the thin section into the graphics package; 
Stage 2 - enlarge (zoom in) the image so that the fine sand grains (down to c. 0.05 $\mathrm{mm}$ in diameter depending on the quality of the scan) are clearly visible and, on a separate layer, digitise the long axes of the included detrital (skeleton) grains working systematically across the thin section. If using CorelDraw, then the length and orientation of each line (long axis) is displayed at the bottom of the window and can be recorded. Consequently, a large data set of 2D clast long axis orientations can be obtained from either the whole, or key parts of the thin section. Data can be obtained for all clasts with an aspect ratio of $>1.1$, over a wide range of grain sizes (very fine sand to small pebble). During this stage of the process the presence of other microstructures (such as rotational structures, arcuate grain alignments, plasmic fabrics, water-escape conduits, folds...etc) and lithological boundaries (layering, bedding....etc) should also be digitised providing a complete interpretation or 'map' of the microstructures and microfabrics present within the thin section. This allows the spatial distribution and relationships between successive generations microstructures and fabrics to be established during Stage 5.

Stage 3 - long axis orientation data for either the whole thin section, or key areas of the thin section, are plotted on a series of rose diagrams allowing the identification of the principle clast microfabrics within the sample. Plotting a series of diagrams for different parts of the thin section and/or from different lithological units within the diamicton allowing any systematic variations in the orientation of the main clast microfabrics to be established and the effect of till composition on these microfabrics to be assessed;

Stage 4 - using a different line style, highlight/define the main clast microfabrics in the thin section. These microfabrics are defined by the preferred alignment of the long axes of the clasts, so it is a simple case of drawing lines to pick out the 'trains' of aligned grains;

Stage 5 - identification of clast microfabric domains and microstructural interpretation of the till. These are defined as areas in which the included detrital grains exhibit the same preferred alignment. This is a simple process of drawing a polygon around the area. Comparison of these domains with the orientation data plotted on the rose diagrams (plotted during Stage 4) allows the identification/characterisation of the main clast microfabrics developed within the specimen. This comparison also provides a means of validating the microfabric domains being differentiated on the developing 'microstructural map' hence avoiding the potential for over interpretation. Different coloured fills can be used to identify these different clast microfabrics. Particular care should be taken to clearly represent any cross-cutting or similar relationships between the various clast microfabrics and other microstructures identified within the thin section. This information forms the basis on which the relative age of the successive generations of microfabrics and structures can be established.

Once completed the diagram represents a 2D microtextural-microstructural 'map' of the entire thin section. To fully characterise the range of fabrics developed within a diamicton (or other deformed glacial sediment) in 3D, the analysis must be carried out on three mutually perpendicular thin sections, ideally cut from the same sample. Orientation data for the microfabrics obtained from each 2D thin section can be used 
to reconstruct the original dip and strike of the fabrics in 3D using a lower hemisphere stereographic projection (see case study 2 for an example).

Figure 2 is a completed 'map' of the clast microfabrics and microstructures developed within the sandstone-rich Dalcharn Lower Till (sample N7126) exposed in a river section at Dalcharn West [NH 8144 4528], near Inverness, NE Scotland. This very poorly sorted, texturally and compositionally immature, matrix-supported diamicton is interpreted as a subglacial traction till (Evans et al., 2006) and was deposited by ice flowing west to east across the area (Walker et al., 1992). It comprises angular, to subangular coarse sand to small pebble sized rock fragments (largely composed of Devonian sandstone) in a medium- to fine-grained sandy matrix. Based upon the density and grain size of the included detrital (skeletal) grains the thin section has been divided into three lithologically distinct areas (Figure 2). The boundaries between these areas are irregular and can be recognised at higher magnification by a change in the composition (clay versus silt-grade component) and/or colour of the silty matrix. Figure 3 illustrates how the 'microstructural mapping' approach has been used to compare the range microstructures developed within a subglacial traction till to those present within an underlying sequence of polydeformed laminated lake sediments (sample S98556) from Raitts Burn [NH 760 047 - NH 796 026], a tributary stream of the River Spey, Strathspey, Scotland. The poorly sorted diamicton is rich in locally derived metasedimentary and granitic rock fragments and was laid down by wet-based ice advancing towards the NNW across a proglacial ice-damned lake (Phillips and Auton 2000).

A description of the various microfabrics and fabric relationships developed within both of the thin sections illustrated in Figures 2 and 3 are included in the following section.

\section{Terminology for the description of the clast microfabrics}

The terminology proposed for the description of the clast microfabrics in glacial sediments follows the system used by petrologists (Powell 1979; Borradaile et al., 1982; Passchier and Trouw 1996) for the description of cleavage and/or schistosity developed in metamorphic rocks, and is illustrated in Figure 4. In metamorphic rocks the classification is based upon the fabric elements that define the foliation such as elongate or platy grains, compositional layers of lenses, or planar discontinuities. Consequently, this scheme can be easily applied to clast microfabrics and any related plasmic fabrics developed within glacial sediments as these fabrics are defined by shape-aligned detrital (skeleton) grains and optically aligned platy clay minerals, respectively. The distribution of the clast microfabric elements in the diamicton defines whether the foliation is spaced (preferred clast alignment preferentially developed within discrete zones of domains) or continuous (preferred clast alignment homogeneously developed throughout the thin section) (Figure $4 \mathrm{a}$ and b). Spaced microfabrics can be divided into two types of domains; (i) the microfabric domains in which the clasts show a pronounced preferred shape alignment and (ii) the intervening microlithons (Figure 4b, c and d) which either have a weak or no preferred fabric, or contain relicts of earlier formed microfabrics (e.g. S1 = first fabric) oblique to the later microfabric domains (e.g. S2 = second fabric). The transition from the microfabric domain to microlithon may be either gradational or discrete (sharp). Spaced fabrics can be further subdivided based upon the structures present within the microlithons. If they contain microfolds the term crenulation foliation (Figure $4 \mathrm{e}$ and 
f) should be applied, if not the structure is known as disjunctive foliation (Figure 4c and d). Other morphological features which can be used to describe spaced foliations are: (i) the spacing of the microfabric domains (Figure 4g); (ii) the shape of the microfabric domains (e.g. rough, smooth, irregular; Figure 4h); (iii) the percentage of the microfabric domains within the diamicton (Figure 4i); and (iv) the spatial relation between the microfabric domains (e.g. parallel, anastomosing, conjugate; Figure 4j). The simple calculation of the spacing of the microfabric domains (spacing = length (L)/number of domains (N); Figure 4g) may also be used to provide a quantitative assessment of the relative intensity of a particular fabric. Diamictons are typically complex polydeformed deposits, the cross-cutting relationships displayed between successive generations of microfabrics can be used to unravel the sequential stages of this deformation history (Figure 4k). It is proposed that the nomenclature normally used in structural studies of polydeformed and metamorphosed bedrock terranes should be applied to discriminate between these microfabrics with S1 representing earliest fabric present within a thin section, to Sn latest (see Figure 4k). Primary sedimentary fabrics, such as the bedding-parallel alignment of elongate detrital grains should be referred to as SO.

The ease of application of this terminology can be clearly demonstrated using the Dalcharn Lower Till (Figure 2) as an example. Three, successive generations of clast microfabrics (S1, S2, S3) have been recognised within this polydeformed diamicton. All three fabrics are classified as rough or discontinuous, spaced foliations defined by lens-shaped microfabric domains. The earliest fabric, S1, (green on Figure 2) is most pervasively developed in area $\mathrm{A}$ and, to a lesser extent, the upper part of area $\mathrm{B}$, and takes the form of a steeply inclined, heterogeneous disjunctive foliation that is deformed by a number of open, inclined folds with moderately to gently inclined axial surfaces which dip towards the west. Arcuate to circular grain alignments (where developed) are preserved within the microlithons between the S1 microfabric domains (Figure 2), indicating that these turbate structures formed prior to, or during the early stages of the imposition of the S1 fabric. The second fabric (S2) (blue, on Figure 2) occurs axial planar to these folds (which are therefore F2 in age) and takes the form of a moderately to poorly developed (heterogeneous) gently to moderately inclined spaced crenulation foliation. S1 is preserved within the intervening S2 microlithons where it is deformed by small-scale microfolds (crenulations) or takes the form of short arcuate to sigmoidal domains oblique to, and crosscut ( $\mathrm{S} 1$ is truncated by $\mathrm{S} 2$ ) by the second fabric (Figure 2). The third fabric (S3) (brown on Figure 2) only occurs in the lower part of the thin section where it cuts across both S1 and S2 (Figure 2). The heterogeneous nature of fabric development within the Dalcharn Lower Till clearly indicates that on a small scale deformation was being focused (or partitioned) into discrete zones within this subglacial traction till, and that this pattern of deformation partitioning changed overtime. Furthermore as deformation proceeded from the imposition of S1, followed by folding of this fabric and the development of S2, through to the development of S3, deformation was potentially being concentrated into progressively narrower zones within the diamicton; possibly equated to the dewatering and overall locking up of the system and cessation of subglacial deformation.

An example of how the microstructural mapping technique may be used to correlate between the deformation histories recorded by a subglacial traction till diamicton and the more obviously folded and faulted, glacial sediments is shown in Figure 3. The 
polyphase deformation history recorded by the glacially overridden glaciolacustrine deposits exposed at Raitts Burn has previously been described by Phillips and Auton (2000) (also see Phillips et al., 2007), and comprises four phases:

- Phase 1, initial loading/compaction of the sediments (pure shear) by the overriding ice, resulting in the imposition of a bedding-parallel throughout the rhythmites;

- Phase 2, heterogeneous deformation of this early fabric by kink bands and narrow ductile shears defined by a locally well-developed unistrial plasmic fabric;

- Phase 3, increasing pore water pressure within the lake sediments during subglacial deformation led to soft-sediment deformation and localised liquefaction of the sands and silts, and formation of clay cutan and sand-filled hydrofractures; and

- Phase 4, subsequent folding and faulting within the uppermost part of the sequence resulting from simple shear imposed by the overriding ice.

This sequence was largely based upon the macro- and microstructures structures which deform the lake sediments. The deformation history recorded by the overlying, apparently more massive till, however, was relatively poorly constrained. Figure 3 is a completed microstructural map of the uppermost sample collected by Phillips and Auton (2000) and includes the boundary between the diamicton and underlying rhythmically laminated lake sediments. It reveals that the diamicton is deformed by two spaced, rough or discontinuous foliations defined by lens-shaped microfabric domains clast microfabrics. These microfabrics form a distinct conjugate pattern within this subglacial traction till. The first of these fabrics, designated S1 (pale purple on Figure 3), dips at approximately $30^{\circ}$ to $40^{\circ}$ towards the NNW (i.e. dipping down-ice) and occurs parallel to (in this plane of section) a gently to moderately inclined stratification and layer-parallel plasmic fabric present within the diamicton. The stratification is defined by the variation in modal proportions of both the clay matrix and sand-grade clasts within the till. Both S1 and the layer-parallel plasmic fabric were observed wrapping around the larger lithic clasts contained within the till, with the asymmetry of these fabrics recording a dextral sense of shear (i.e. towards the NNW). Orientation data obtained for S1 indicates that it is coplanar to the unistrial plasmic fabric/ductile shears and normal faults, developed during deformation phases 2 and 4 respectively, within the underlying sands, silts and clays (see the rose diagrams on Figure 3). The second, more pervasively developed clast microfabric (S2) identified within the diamicton (blue on Figure 3) dips at $40^{\circ}$ to $50^{\circ}$ towards the SSE (i.e. dipping up-ice) and occurs parallel to a heterogeneously developed unistrial plasmic fabric present within its matrix (see the rose diagrams on Figure 3); the latter defines a set of closely spaced ductile shears with a dextral off-set, consistent with an overall sense of displacement towards the NNW. These relationships suggests that both S2 clast microfabric and unistrial plasmic fabric were imposed simultaneously, with rotation of the detrital (skeletal) grains occurring at the same time as localised ductile shearing within the finer grained clay-rich matrix. S2 and the spatially related shear fabric define a 10-12 mm wide zone of enhanced ductile shear (green area on Figure 3) which clearly offsets the contact between the diamicton and rhythmites. This zone can be traced into the underlying laminated sediments where it occurs parallel to a set of well-developed (Phase 4) reverse faults (see Figure 3). 
The orientation and kinematics recorded by all the microstructures present within both the diamicton and underlying lake sediments are consistent with their formation in response to the same stress regime imposed as the ice overrode the Raitts Burn area towards the NNW. The observed differences in the style and apparent intensity of deformation displayed by the deposits can be directly related to the contrasting lithology and potentially much higher pore-water content and/or pressure occurring within the diamicton during subglacial deformation.

\section{A comparison of the microfabrics in diamictons with those present in metamorphic and igneous rocks}

Figure 5 shows examples of the detailed microfabric relationships identified within two samples of a sandy till exposed in Riereach Burn (N7129, [NH 83903 43151], Figure 5a and b; N7132, [NH 84530 44132], Figure 4c and d), near Nairn, NE Scotland. These features include the wrapping of the microfabric domains around larger, granule to pebble sized clasts (Figure 5a); the preservation of earlier formed microstructures, such as arcuate grain alignments (turbate structures) and crenulations, and earlier fabrics (e.g. S1) within the microlithons of the later fabrics (e.g. S2) (Figures 5b and c); pressure shadows adjacent to larger, apparently immobile clasts (Figure 5a); and the localised microfolding associated with shearing within the matrix immediately adjacent to pebble sized clasts (Figure 5d).

In general terms the morphology of the clast microfabrics identified within diamictons are similar to microstructures developed within polydeformed metamorphic and foliated igneous rocks (compare Figure 5 with Figures 6 and 7). Examples of these bedrock deformation structures are shown in Figures 6 and 7, and include: a spaced domainal schistosity wrapping around garnet porphyroblasts in an amphibolite facies garnet-biotite-muscovite schist (Figure 6a and b); pressure shadows developed adjacent to garnet (Figure 6b) and "snowball" (rotated) garnet porphyroblasts (Figure $6 \mathrm{c}$ ); crenulation foliations (Figure $6 \mathrm{~d}$ to $\mathrm{f}$ ) overgrown by post-kinematic andalusite (Figure 6d) and microcline (Figure 5f) in amphibolite facies metasedimentary rocks; shape-aligned, euhedral plagioclase phenocrysts in a basalt lava flow defining a pilotaxitic (flow) fabric (Figure 7a); shape-aligned, subhedral to euhedral hornblende phenocrysts is a high-level andesite intrusion defining a moderately developed pilotaxitic (flow) fabric (Figure 7a); elongate, deformed single quartz crystals aligned parallel to a well-developed mylonitic fabric present within a mylonitised metasandstone; and well-developed shear fabrics within a highly deformed low-grade (sub-greenschist facies) wacke metasandstone in which the softer, more easily deformed mudstone clasts have become highly attenuated and streaked out in the plane of the shear fabric.

Although it is tempting to directly compare the microstructures in tills with those resulting from the deformation of metamorphic and mylonitic rocks and, therefore, the deformation processes occurring in both situations, there are two fundamental differences that should be borne in mind when attempting such a comparison:

1. In metamorphic and mylonitic rocks the strains encountered are significantly higher than those in deformed glacial sediments. Work by Iverson et al. (1996), van der Wateren et al. (2000), Thomason and Iverson (2006) has shown that the strains encountered during subglacial deformation are typically much lower than expected and deformation structures typically equated with 
high shear strains (e.g. sheath folds) may be developed at much lower values of cumulative strain due elevated pore water pressures/contents encountered in these potentially water saturated sediments;

2. The cleavage and/or schistosity in a metamorphic rock is defined by minerals which have actively grown during fabric development as a result of the deformation being accompanied by a prolonged period of elevated temperature and pressure. New mineral/grain growth is not common in glacial sediments and, where present, is typically equated with the diagenetic (very low temperature) growth of carbonate minerals from solution within subglacial tills (e.g. van der Meer et al., 2003).

Clast microfabrics in tills are developed in response to the passive rotation of the skeletal or detrital grains (see Carr and Rose 2003, Carr and Goddard 2007 amongst others). Deformation of the individual clasts tends to be restricted to very localised cataclasis or grain fracturing resulting from high strains at inter-grain contacts or elevated pore water pressures (see Hiemstra and van der Meer 1997). Cataclasis, where developed, tends be aided or partially controlled by the polymineralic or polycrystalline nature of the clasts, or the presence of inherent weaknesses within the grain, such as pre-existing fractures and/or intracrystalline weaknesses (e.g. dislocations, cleavage, twin planes). In some tills, relatively soft, mud intraclasts and till pebbles (van der Meer 1993) exhibit little or no evidence of deformation and/or attenuation, providing indirect evidence for relatively low shear strains encountered during the deformation of these deposits. Compare this observation with the highly attenuated mudstone clasts within the sheared wacke sandstones from the Moniaive Shear Zone in southern Scotland (Phillips et al., 1995) shown in Figures 7d and e. Deformation of the sandstones within this shear zone led to clast rotation, the growth of fine-grained white mica beards within the pressure shadows, cataclasis of detrital grains and the development of a range of fabrics ( $\mathrm{S}-\mathrm{C}$ fabrics, extensional crenulation cleavage (ECC), shear bands; Passchier and Trouw 1996) associated within the ductile shearing of these very low grade (sub-greenschist facies) metamorphic rocks. Although the clastic nature of these deformed sandstones can clearly still be seen, all of the included mudstone intraclasts have become 'streaked out' within the plane of the shear fabric (see Figures $6 \mathrm{~d}$ and e).

Although grain rotation and clast microfabric development in glacial sediments occurs at very low temperatures (e.g. the range -5 to $+5^{\circ} \mathrm{C}$ ), in general terms, the process is broadly comparable to the formation of pilotaxitic (flow) or pre-full crystallisation fabrics in extrusive and plutonic igneous rocks (temperatures in excess of 700 to $800^{\circ} \mathrm{C}$ ), respectively, where the crystals are passively rotated during magmatic flow of a highly viscous liquid (magma or lava). The potential similarities between fabric development within water saturated tills and partially crystallised igneous rocks has previously been highlighted by Evans et al. (2006). Pre-full crystallisation fabrics or foliations, as the name suggests, form during the emplacement of the igneous intrusions due to displacement (flow) of the partially crystallised magma prior to final solidification (Borradaile 1986; Hibbard 1987; Hutton 1988; Paterson et al., 1989; Cruden 1990; Phillips and May 1996). Paterson et al. (1989) published a number of criteria for recognising foliations in granitic rocks formed by magmatic flow, these are: (i) a preferred orientation of primary igneous minerals that show no evidence of plastic deformation or recrystallisation of either of the crystals or interstitial minerals; 
(ii) aligned crystals are surrounded by anhedral, non-deformed quartz or non-aligned aggregates of quartz, implying magmatic alignment as quartz is a sensitive indicator of solid-state flow (deformation); and (iii) imbrication of tiling of crystals resulting from non-coaxial magmatic flow involving rotation of crystals in a viscous fluid. The features identified by Paterson et al. (1989) as indicators pre-full crystallisation fabric development in igneous rocks are similar to the range of microfabric relationships identified within tills. This suggests that diamictons may be responding in a similar way to an applied stress regime as they dewater, changing from a highly dilated, water-saturated sediment, in which deformation is accommodated by viscous flow, through to a stiffer deposit capable of undergoing solid-state deformation.

An example of a pre-full crystallisation fabric developed within an appinitic diorite intrusion from Glas Bheinn, Glen Roy in the Scottish Highlands (Phillips and May 1996) is shown in Figure 8. The spaced foliation in this diorite is defined by variably shape-aligned amphibole phenocrysts and elongate, lenticular domains composed of biotite; the overall morphology of this igneous fabric is comparable to the clast microfabrics present in the tills illustrated in Figures 2 and 5. Phillips and May (1996) argued that foliation development within these appinitic rocks occurred in response to the heterogeneous collapse of a crystal framework which formed prior to full crystallisation (Figure 9), probably in response to deformation associated with the continued forceful emplacement of the intrusion. The collapse of this framework led to the passive rotation of amphibole and biotite crystals to form a well-developed domainal foliation with the remaining interstitial melt locally being expelled to form the more felsic domains richer in late crystallising, randomly orientated plagioclase and quartz. Some plutonic igneous rocks may, of cause, show evidence of the superimposition of later solid-state deformation upon an earlier formed magmatic prefull crystallisation fabric, leading to, for example, intracrystalline deformation and the development of sub-grain structures in minerals such as quartz, grain size reduction and elongation in response to dynamic recrystallisation, and microboudinage of stronger minerals (e.g. feldspar).

\section{Case Studies: illustrations of the potential of the microstructural mapping technique to analysis of deformed glacial sediments}

The potential of the new microstructural mapping technique as an aid to the analysis and interpretation of deformed glacial sediments can be illustrated using three case studies: (i) a thin section of glacially faulted gravel from Dinas Dinlle in North Wales; (ii) three thin sections from a flute exposed during the annual retreat of the Turtmann Glacier in Switzerland; and (iii) three thin sections of a subglacial traction till from Riereach Burn, near Nairn in NE Scotland. Details of the glacial history/setting of the individual sites are briefly described to provide the overall context of the thin sections. For a more detailed description of the glacial histories of the study areas the reader is referred to the references cited in the text. The samples included within these case studies were selected as they were shown to contain well-developed clast microfabrics, therefore providing ideal illustrations of how to apply this new technique and interpret the resultant microstructural maps.

\section{Case Study 1: Faulted gravel, Dinas Dinlle, North Wales}

Dinas Dinlle on the western coast of Llyn Peninsula in North Wales was located at the eastern margin of the Late Devensian Irish Sea Ice Stream (Thomas and Chiverrell 
2007). The complexity of the polydeformed glacial sequence exposed at this locality is primarily due to its proximity to the confluence zone between the Irish Sea Ice Stream and the adjacent Welsh Ice Sheet, located to the east and centred upon Snowdonia (see Harris et al., 1997; Hart 1990, 1995; McCarroll 1995; Thomas and Chiverrell 2007). At Dinas Dinlle the glacigenic sediments are exposed in two main sections: the larger, more northerly section comprises a stacked sequence of highly glaciotectonised diamictons and outwash sands and gravels; with the smaller, southerly section being dominated by highly deformed sands and gravels (Harris et al., 1997). Glacitectonism, which includes major thrusting, has been interpreted by Thomas and Chiverrell (2007) as having occurred in response to ice-marginal deformation associated with the active retreat of the Irish Sea Ice Stream (also see Harris et al., 1997).

Sample Description: Sample DD09 3/1 is of a faulted gravel taken from the southern limb of a large-scale, asymmetrical anticline deforming a thick sequence of moderately well-bedded, coarse sands and gravels exposed at the southern end [SH 43639 56220] of the larger, northern section at Dinas Dinlle (Figure 10). In outcrop the steeply inclined to subvertical, normal fault (downthrow to the north) clearly offsets bedding within the sands and gravels and is marked by a narrow zone of deformation and manganese staining. A pronounced displacement gradient has been recognised on this brittle structure with the amount of displacement decreasing upwards, from c. $12 \mathrm{~cm}$ near the centre of the exposed fault plane, to less than $6 \mathrm{~cm}$ towards its tip. In thin section (Figure 11) the fault deforms a moderately sorted, clast supported gravel composed of subangular to subrounded, low sphericity clasts, dominated by mono- and polycrystalline quartz, slate and sandstone, within a coarse sand matrix. Initial compression associated with compaction of the sediment resulted in localised deformation of the more unstable mudstone clasts which have become distorted or partially wrapped around neighbouring more rigid quartzose grains. One of the most prominent features of this thin section is the fact that elongate coarse sand to small pebble sized clasts exhibit a pronounced preferred shape-alignment and define a very well-developed bedding-parallel clast microfabric (Figure 11). This fabric is clearly deformed by a subvertical fault marked by a 5 to $10 \mathrm{~mm}$ wide zone of deformation in which the clasts within the gravel have been re-orientated. In detail the fault is composed of several dislocations denoted by marked changes in the clast orientation. On the northern side, or footwall of the fault the bedding-parallel fabric dips at approximately $50^{\circ}$ to the north, whereas in the hanging wall the clast macrofabric dips more gently (c. $20^{\circ}$ ) toward the south. Adjacent to the fault the fabric steepens up and is folded by an open, upright asymmetrical fold (Figure 11). The axial surface of this fold is coplanar with the adjacent fault. Subsequent migration of pore water through the sediment resulted in the deposition of a thin manganese and/or hematitic coatings on clasts within the fault zone.

Results of the microstructural mapping: The completed microstructural map of sample DD09 3/1 is shown in Figure 11. The well-developed primary beddingparallel clast macrofabric (S0, yellow in Figure 11) is clear and can be classified as a relatively smooth, zonal (approximately 70 to 75\%), spaced foliation composed of elongate, parallel microfabric domains. In the intervening microlithons the clasts locally exhibit a pronounced alignment and stacking, thought to preserve the original sedimentary imbrication of the detrital grains formed as the gravel was being deposited. The S0 bedding-parallel microfabric is folded by an open, upright, 
northerly verging asymmetrical fold, the hinge area of which has clearly effected by deformation associated with the subvertical normal fault (Figure 11).

Detailed mapping of the clast microfabrics has revealed that the fault zone is composed of two distinct zones: (i) a wedge-shaped $(40 \mathrm{~mm}$ wide at its base, narrowing to $10 \mathrm{~mm}$ at the top) outer zone (Zone 1) within the lower part of the fault (green zone in Figure 11) defined by a relatively pervasive, continuous clast microfabric in which the majority of the clasts exhibit a preferred alignment dipping at $38^{\circ}-40^{\circ}$ towards the north; and (ii) a central, narrower $(17 \mathrm{~mm}$ wide at the base, narrowing slightly to $12 \mathrm{~mm}$ at the top of the thin section) zone (Zone 2) characterised by a steeply inclined (c. $68^{\circ}$ ) northerly dipping, continuous clast microfabric (blue zone on Figure 11). Both of these zones are denoted by marked changes in the clast macrofabric orientation, resulting from the reorientation of sand to pebble sized detrital grains within the fault zone and overprinting of the S0 bedding-parallel foliation. The boundaries between the two zones are sharp, indicating that they represent at least two separate phases of movement on the fault, each accompanied by a phase of fabric development/realignment. A curved to sigmoidal pattern to the macrofabric within the lower part of Zone 1 records a steeply inclined sinistral sense of shear consistent with the overall normal sense of displacement on the fault (Figure 11). The more extensive Zone 2 can be traced across the entire thin section and clearly cuts across Zone 1 (Figure 11), providing a clear relative age relationship between the phases of movement (Zone $1=\mathrm{S} 1$, earlier; Zone $2=\mathrm{S} 2$, later) resulting in microfabric development within these zones, with the narrower Zone 2 recording a focusing of deformation during the later phase(s) of movement along the fault. The orientation and sinistral sense of shear recorded by locally developed sigmoidal microfabric geometry within Zone 2 (see Figure 11) indicates that both zones record a similar normal fault displacement. In the lower left-hand part of the thin section, Zone 2 bifurcates and encloses a lenticular area of Zone 1 microfabric which, itself, contains a relict of the $\mathrm{S} 0$ bedding-parallel microfabric developed in the adjacent hanging wall and footwall of the fault (Figure 11).

Discussion and interpretation: Figure 12 shows a simple three stage model involving earlier folding followed by later brittle faulting to explain the deformation history recorded by the gravel. Initial deformation (D1) resulted in the development of the upright, asymmetrical fold which deformed a pre-existing, pervasive bedding-parallel (S0) microfabric. S0 is thought to have formed during the deposition of the gravel, but was possibly intensified due to compression in response to compaction of the sediment which led to localised distortion and moulding of softer mudstone rock fragments around neighbouring more rigid quartzose clasts. It is possible that folding of the gravel occurred in response to a completely separate deformation event. Although the fault clearly cuts across and, therefore, post-dates folding, the axial surface of the fold is coplanar with the adjacent fault indicating a possible relationships between these two structures. Consequently, the alternative interpretation, favoured here, is that folding occurred immediately above the propagating fault tip (Stage 1 on Figure 12). As the fault propagated upwards, it progressively deformed the earlier fold, penetrating along the hinge of this structure. Microfabrics within the fault zone clearly indicate that this brittle structure accommodated two phase of movement. Zone 1 represents the earlier phase of movement which resulted in a wedge-shaped zone of deformation immediately surrounding the fault (Stage 2 on Figure 12). The intensity and extent of this 
deformation decreased towards the tip of the fault. The more steeply inclined Zone 2 represents a later, second phase of movement and fault propagation during which the fault tip cut through the remainder of the sediment and earlier formed Zone 1, and was accompanied by a much narrower zone of clast microfabric development (Stage 3 on Figure 12). This marked difference in the orientation and extent of Zones 1 and 2 on Figure 11, and the microfabrics they contain, indicates that there was a minor change in the stress regime being applied to the gravel during fault propagation, possibly with a cessation or pause in deformation separating Stages 1 and 2. At an apparently much later date, pore water migrating through the gravel utilised the fault as a fluid pathway resulting in localised mineralisation (manganese, hematite) within this zone.

The detailed deformation history erected for the sample of faulted gravel from Dinas Dinlle clearly illustrates the potential of both micromorphology and the proposed microstructural mapping technique as an aid to understanding the propagation of larger scale glacitectonic structures (e.g. folds, faults) through a deforming sedimentary sequence. Careful analysis of the microfabrics and associated microstructures developed within these larger scale structures also has the potential to identify subtle changes in the stress regime being applied to the sediments during their development, therefore providing a greater understanding of the deformation processes.

\section{Case Study 2: Flute composed of till, Turtmann Glacier, Switzerland}

The $5 \mathrm{~km}$ long (2005) Turtmann Glacier is located to the north of the Weisshorn in the Pennine Alps in Switzerland. Between 1986 and 1997 a series of small flutes (Figure 12a), ranging in length from a few decimetres to a few metres, were formed and subsequently destroyed as a result of annual oscillations of this glacier (van der Meer 1997). The ice at the base of this glacier is debris-free, with the sediment forming the flutes being interpreted as having been derived from within the bed. Van der Meer (1997) concluded that the flutes emerging from the front of the Turtmann Glacier developed only when the sediment distribution and properties of the bed, the thickness of the ice, and its horizontal velocity are within a certain range, with these elongate bedforms forming as a result of the squeezing of till from the underlying bed into a cavity formed in the lee of large boulders protruding into the base of the overriding ice.

Sample Description: Three mutually perpendicular samples of till $(0.831,0.832$, 0.833) were taken from a small flute formed in the lee of a large boulder (Figure 13) and exposed in a portal (Figure 13a) during the 1986 annual retreat of the Turtmann Glacier. The vertically aligned Kubiena format thin section 0.831 (Figure 14) was cut parallel to the long axis of the flute; the latter being orientated at approximately $015^{\circ}$ (see Figure 13b). The second Kubiena format thin section 0.832 (Figure 15) represents a plan section through part of the flute, with its longer edge parallel to the long axis of this bedform. The vertically aligned mammoth thin section, 0.833 (Figure 16), represents a strike section through the flute (Figure 13b). Although they have been cut from three separate samples, these mutually perpendicular thin sections do still allow for deformation structures developed within the flute to be examined in $3 \mathrm{D}$ (see below).

Thin sections of samples 0.831 and 0.832 clearly show that the flute is composed of two compositionally distinct diamictons: (i) a poorly sorted, open-packed and matrix- 
supported till with a dusty looking grey-green silty sand matrix; and (ii) a similarly poorly sorted, but matrix-poor, clast-rich diamicton (Figures 14 and 15). The contact between these two diamictons is sharp and highly irregular in form. The clast assemblage in both of these diamictons, however, is the same, indicating that the primary lithological difference between the two tills is the modal percentage of matrix. The low sphericity, angular to locally subrounded, coarse sand grains and pebbles are mainly composed of variably retrogressed, schistose metamorphic rock fragments. Silt- to sand-grade clasts within the matrix are more angular in shape and are dominated by mono- and polycrystalline quartz grains, as well as minor plagioclase, granular looking epidote and amphibole. The finer grained components within the matrix are dominated by small flakes of white mica and chlorite. The elongate shape of the lithic clasts appears to be largely controlled by the presence of a moderate to well-developed schistosity within these metamorphic rocks.

At low magnification, a moderately well-developed preferred alignment of the clasts can be recognised within the clast-rich till. However, in the more matrix-rich diamicton, the presence of such a clast microfabric is less apparent and the till appears massive. The only other recognisable microstructures present within this matrix-rich till are locally developed arcuate grain alignments that partially enclose granule to pebble sized clasts (Figures 15 and 16). No other glacitectonic structures (folds, faults, shears, plasmic fabrics) have been recognised within these tills.

Results of the microstructural mapping: The completed microstructural maps of samples 0.831, 0.832, 0.833 are shown in Figures 14, 15 and 16. Analysis of the data has revealed that both till lithologies present within the thin sections possess a moderate- to well-developed, steeply inclined, spaced, anastomosing (disjunctive) clast microfabric (S2) defined by irregular microfabric domains that are lenticular in shape. This foliation clearly cross-cuts the lithological boundary between the two types of till (see Figure 15). The slight difference in clast orientation data obtained for this fabric in each of the diamictons present in sample 0.831 (Figure 14) may record its refraction due to the differences in till lithology (cf. cleavage refraction in graded sandstone beds, or within interbedded cleaved thinly interbedded slate and metasandstone sequences; see Ramsay 1967, pages 405-406). The spacing of the microfabric domains appears to have been controlled by the grain size of the larger skeleton grains, with these granule to pebble sized clasts showing a moderate- to welldeveloped preferred alignment parallel to the enveloping foliation (Figure 14). Adjacent to these larger clasts the till within the microlithons is massive, lacking any obvious microfabric. However, a weakly developed, more gently inclined, apparently earlier (S1) spaced macrofabric can locally be recognised within the wider and more pervasive (S2) microlithons (Figure 14). The same two microfabrics can be recognised within sample 0.832 where they display a weak to moderately developed conjugate relationship (Figure 15). S1 is clearly better developed within this sample and is locally deformed by the hinges of small-scale microfolds, with S2 taking the form of a spaced crenulation microfabric, rather than the more widely developed disjunctive foliation. The intensity of $\mathrm{S} 1$ further increases within sample 0.833 , with $\mathrm{S} 1$ becoming more pronounced on the western side of the thin section. The microstructural relationships between $\mathrm{S} 1$ and $\mathrm{S} 2$ are, however, less clear cut than in the other thin sections. Locally in sample 0.833 (as in sample 0.832) S1 is preserved as a crenulation within the microlithons of the relatively younger S2 fabric (Figure 16). Elsewhere within this thin section, however, S1 apparently cross-cuts S2 
indicating that the relative timing of the imposition of the two fabrics has been reversed. These relationships suggest that the relative age relationships of microfabric development are far more complex than in sample 0.832, possibly reflecting the different rates at which the developing fabrics are propagating through different parts of the till. Although the S2 fabric is the dominant foliation, available evidence suggests that there is an overall increase in the intensity of S1 towards the western side of this subglacial bedform. Arcuate grain alignments, typically equated with the development of turbate structures and the rotation of larger clasts (van der Meer 1993, 1997), are rarely developed/preserved within samples 0.832 and 0.833 (Figures 15 and 16, respectively) where they occur within the S2 microlithons and appear to be truncated by this fabric; indicating that they were developed prior to the imposition of $\mathrm{S} 2$. The relict rotational structures, where present, are preserved in microlithons between both $\mathrm{S} 1$ and $\mathrm{S} 2$, in particular within the pressure shadows developed immediately adjacent to the larger lithic clasts. These relationships indicate that the development of these turbate structures occurred early during deformation, probably prior to the imposition of the clast microfabrics.

The three mutually perpendicular thin sections taken from the flute (see Figure 13b) has allowed the 3D geometry of the various structures present within this bedform to be investigated. Figure 17 is a schematic 3D block diagram showing the relationships between $\mathrm{S} 1$ and $\mathrm{S} 2$, with the more pervasive S2 fabric clearly wrapping around the larger clasts. These larger clasts acted as rigid bodies within the softer, more easily deformed matrix, with deformation being preferentially partitioned into this silty sand. The grain size of the granules and pebbles clearly affected the scale of this partitioning, controlling the spacing of the developing S2 microfabric domains. Although S1 and S2 have been recognised within both the clast-rich and matrix-rich tills, they are more pervasively developed within the matrix-rich diamicton (see Figures 15 and 17), providing evidence for the heterogeneous nature of fabric development. The increase in fabric intensity within the matrix-rich till is thought to be a direct reflection of its overall texture and composition. The relatively open packing of detrital grains within this till would have enabled the individual clasts to rotate more easily, promoting/enhancing fabric development. Whereas, in the clastsupported, matrix-poor till the very closely spaced skeleton grains would have interfered with one another, impeding clast rotation and, therefore, restricting the imposition of a microfabric. This 'nearest neighbour effect' on microfabric development would have increased as the till progressively dewatered. Initially when a till is water saturated and dilated, the clasts would possess a greater degree of freedom to rotate. This 'rotational freedom' would have been even higher within the matrix-rich till due to the increased separation between the coarser grained clasts provided by the fine-grained matrix. The preservation of apparently early formed relict turbate structures within the microlithons between $\mathrm{S} 1$ and $\mathrm{S} 2$ provides a record of this rotational deformation/flow when the till was in a more dilated state. However, as the pore water pressure and/or content decreases, there would have been a corresponding decrease in till dilation, leading to an increase in inter-grain contact, impeding clast rotation. Essentially, during dewatering the till would have started to 'stiffen' or 'lock up' becoming more resistant to further deformation. The presence of fines (clay, fine-silt grade) within the tills matrix has the effect of lowering its permeability, inhibiting intergranular pore water flow, potentially slowing down the rate at which it dewaters, effectively helping to maintain water saturation. In contrast, the relatively free-draining, clast-rich till would have dewatering more quickly, so it 
would have 'locked up' at an earlier stage during deformation. Consequently, microfabric development may have effectively ceased within the clast-rich till, whilst S2 was continuing to develop and intensify within the adjacent matrix-rich diamicton.

The lithological contact between the two diamictons present in samples 0.831 and 0.832, although sharp, is highly irregular in form (e.g. Figure 15), consistent with model proposed by van der Meer (1997) for the remobilisation and injection of highly mobile till into a cavity formed in the lee of the boulder. The clast microfabrics present in these tills clearly cut across this lithological boundary (see Figures 14 and 15) providing clear evidence that these foliations were imposed after liquefaction and injection associated with the earlier stages of flute formation. These spaced foliations were probably imposed as the till progressively dewatered (see above). Rarely developed arcuate grain alignments, formed in response to the rotation of larger pebble sized clasts (c.f. van der Meer 1993, 1997), are preserved within the S2 microlithons indicating that they were developed prior to the imposition of this fabric, probably whilst the till was water saturated and being injected into the developing flute. As the till dewatered these larger clasts probably became fixed in position with subsequent foliation development being partitioned into its finer grained matrix. As noted above the grain size of the coarser grained clasts strongly influenced the scale of partitioning within the matrix, reflected in the spacing of the developing S2 microlithons.

As previously stated, sample 0.832 (Figure 15) is a plan section through part of the flute and, therefore, the clast microfabric data obtained from this thin section have enabled the strike of both S1 and S2 to be established (see Figure 17). The vertical thin sections 0.831 (Figure 14) and 0.833 (Figure 16) can be used to determine the apparent dips of these microfabrics along the length and across the strike of the flute, respectively. These data, when plotted on a lower hemisphere stereographic projection (Figure $13 \mathrm{c}$ ), allow the mean dip and strike of the $\mathrm{S} 1\left(50^{\circ} \mathrm{NE} / 144^{\circ}\right.$ to $\left.60^{\circ} \mathrm{NE} / 144^{\circ}\right)$ and $\mathrm{S} 2\left(48^{\circ} \mathrm{NW} / 055^{\circ}\right)$ clast microfabrics to be established. On Figure $13 \mathrm{c}$ it is clear that $\mathrm{S} 1$ and $\mathrm{S} 2$ form a conjugate set of microfabrics with the pitch of their intersection $\left(38^{\circ} / 008^{\circ}\right)$ occurring within a few degrees of the flute long axis (orientated towards $015^{\circ}$ ) and, therefore, the dominant ice movement direction during the formation of this bedform. Thin section evidence suggests that these conjugate clast microfabrics are symmetrically disposed about the long axis of the flute (see Figure 13) with their orientation reflecting the overall stress pattern set up in the lee of the large boulder.

Discussion and interpretation: The application of the microstructural mapping technique to the thin sections from an annual flute exposed underneath the Turtmann Glacier has allowed a far more detailed model of their formation to be established. Initial injection of the water saturated till into the cavity developing in the lee of a large boulder projecting from the bed into the overriding clean ice was accompanied by the variable rotation of the larger clasts and the formation of turbate structures within the adjacent matrix. As this lithologically variable till dewatered, the larger clasts became fixed in position and deformation was increasingly partitioned into the finer grained matrix leading to the imposition of a conjugate set of clast microfabrics symmetrically disposed about the axis of the flute. Deformation within the matrix of the till was heterogeneous leading to the foliations being preferentially developed within the more matrix-rich diamicton. Deformation partitioning within the matrix of this till was controlled by the grain size of the larger granules and pebbles, which in 
turn influenced the spacing of the developing microfabric domains. Earlier formed microstructures associated with the earlier injection of the till are variably preserved in the pressure shadows adjacent to the larger lithic clasts located within the microlithons of these foliations. Elsewhere, these earlier formed features appear to have been overprinted during subsequent fabric development. As the flute continued to dewater, deformation within more clast-rich diamicton ceased as this till 'locked up'. Continuing deformation within the more matrix-rich, slower draining till is thought to have continued leading to the further intensification of the microfabrics within this part of the flute. Eventually dewatering had progressed to a point where deformation within the till ceased and flute formation was terminated.

\section{Case Study 3: massive subglacial traction tills, Nairn, NE Scotland}

The N-S trending valley of Riereach Burn occurs on the northern side of Cairngorm plateau some $12 \mathrm{~km}$ to the SW of Nairn in NE Scotland (Figure 18a). The glacial sediments which form the upper part of the sequence exposed in Riereach Burn were deposited by ice which flowed northwards from the Central Highlands towards the coast (Fletcher et al., 1996, Auton et al., 1990) during the main phase of the Late Devensian glaciation of northern Scotland. This sequence is characterised by a suite of brown sandy and silty tills (3-8m thick) interstratified with sands and gravels containing a high proportion of locally derived igneous and metamorphic rock fragments (Figures $18 \mathrm{~b}$ and c). The sequence is capped by coarsening-upward units of outwash sand and gravel laid down as the ice retreated southwards.

Sample Description: Three samples (samples N7128 and N7129, location [NH 83903 43151] and N7132, [NH 8453044132 ]) were taken of a gravelly subglacial traction till exposed in two sections within Riereach Burn. The samples were orientated parallel to the main northerly ice movement direction in this area. In thin section (Figures 19, 20 and 21) the till is composed of a very poorly sorted, texturally and compositionally immature, coarse- to very coarse-grained diamicton with a matrixsupported texture. Angular, subangular, to rarely rounded, low-sphericity coarse-sand to pebble sized clasts within this massive to weakly stratified diamicton are composed of locally derived Neoproterozoic metamorphic and Devonian sedimentary bedrock fragments, as well as occasional granite and basaltic volcanic clast. Sand-grade clasts within the silty sand matrix are dominated by mono- and polycrystalline quartz with minor plagioclase. The coarser grained fragments within the Riereach Burn till locally exhibit a preferred shape-alignment, defining a variably developed clast microfabric (see below). Arcuate grain alignments and turbate structures, defined by chains or bands of silt and fine-sand grains, are developed within the matrix immediately adjacent to granule to pebble sized clasts (Figures 19, 20 and 21; also see Figure 5). A number of these larger clasts are enclosed within, or coated by a thin layer of fine silt and/or clay forming darker haloes around these 'coated grains'. In sample N7128 a very weak layering or stratification, observed at low magnification, is defined by a slight variation in the modal proportion of coarse-sand to pebble sized clasts (Figure 19). Although the matrix contains fine-silt and clay grade material it is apparently lacking in clay minerals. Consequently, no obvious plasmic fabrics have been recognised within this till. Furthermore, no other obvious deformation structures, such as folds and/or faults, have been recognised within the Riereach Burn till.

Results of the microstructural mapping: Although, when viewed under the petrological microscope the subglacial traction till from Riereach Burn appears to be a 
relatively massive deposit, detailed microstructural mapping of the thin sections has revealed a complex pattern of microfabrics developed within this diamicton (Figures 19, 20 and 21). Sample N7128 contains the most complex history of fabric development. The thin section has been divided into three areas (labelled A, B and C on Figure 19) defining a weakly developed, irregular stratification or layering. Three successive generations of clast microfabric have been recognised within the sample: (i) An early, gently to moderately $\left(10^{\circ}\right.$ to $\left.40^{\circ}\right)$ northerly inclined (i.e. dipping downice), variably developed, discontinuous spaced $\mathrm{S} 1$ microfabric which is best developed in area A, in particular within the upper right-hand part of the thin section; (ii) $\mathrm{S} 1$ is cross-cut or deformed (crenulated) by a southerly (c. $30^{\circ}$ to $50^{\circ}$ ) dipping (up-ice), irregular, moderately to closely spaced $\mathrm{S} 2$ disjunctive to crenulation microfabric which is developed throughout the entire thin section. The earlier formed $\mathrm{S} 1$ fabric, here present, is preserved within the S2 microlithons; and (iii) A later, heterogeneously developed, gently to moderately (c $20^{\circ}$ to $30^{\circ}$ ) northerly dipping S3 fabric which has only been recognised in areas A and B where it cross-cuts both the earlier S1 and S2 foliations (Figure 19). All three fabrics are defined by discontinuous to irregular, lenticular microfabric domains, with the spacing of these domains being partially controlled by the grain size of the coarser grained clasts present within the till. Both S1 and S2 are locally observed wrapping around these large clasts. The orientation of the granules and pebbles varies across the thin section, but they appear to be mainly orientated parallel to S1 (see Figure 19).

Orientation data obtained for each of the three areas in sample N7128 show that they each possess a different pattern of clast microfabric (see the rose diagrams on Figure 19). In area $A$, clast orientation data for $S 1$ and $S 2$ fabrics define a distinctive 'bow tie' or conjugate pattern. In detail, however, the relationships between the two fabrics are far more complex. The variation in the attitude of S1 across the upper part of the thin section defines a broad, open fold with a northerly dipping axial surface (Figure 19). S2 occurs axial planar to this fold with the dome-like areas $B$ and $C$ apparently occupying the core of this structure. In the southern or right-hand part of area A, the intensity of S1 clearly decreases and it is replaced or overprinted by the locally very closely spaced S2. Importantly, the spacing of S2 decreases markedly within the finer grained parts of the diamicton indicating that clast grain size is an important factor controlling the spacing of the foliation and, therefore, the scale of deformation partitioning within the matrix of the till. Area B displays a more varied pattern of clast orientation (see Figure 19) with the S2 fabric being the main foliation developed within this more massive part of the till. In area $\mathrm{C}$, which dominates the lower third of the thin section, S2 is the dominant foliation with S1 locally preserved within the microlithons between this second foliation. Orientation data indicates that the clasts defining the S2 foliation within this part of the thin section are more steeply inclined (see Figure 19). S3 is clearly the last fabric to have been imposed in sample N7128, with the highly heterogeneous nature of this microfabric probably reflecting the partitioning of deformation into increasingly narrower zones of shear during the later stages of deformation.

A spaced, anastomosing S2 foliation is the dominant clast microfabric within samples N7129 and N7132 (Figures 20 and 21, respectively). The earlier, more weakly developed, discontinuous $\mathrm{S} 1$ fabric is preserved as short, curved to sigmoidal microfabric domains or crenulations within the S2 microlithons (Figures 20 and 21, also see Figure 5). The axial planes of the crenulation-style (F2) microfolds that 
deform S1 are coplanar to the enveloping S2 fabric. In sample N7132 the crenulated S1 fabric is well-developed/preserved immediately adjacent to a pebble of metasandstone (Figures 21 and 5d), with the asymmetry of the microfolds indicating a northerly directed sense of shear. In sample N7129, a rounded pebble of feldspathic sandstone near the top of thin section is clearly wrapped by S2 (Figures 5a and 20). Asymmetrically disposed pressure shadows developed adjacent to this pebble yield a sinistral (top to left), northerly directed sense of shear (Figure 20). These microtextural relationships clearly indicate that coarse-grained rock fragments within the Riereach Burn till acted as rigid bodies during deformation, with S2 fabric development being forced to partition around these apparently immobile objects. Furthermore, the sense of shear obtained from these and spatially related structures is consistent with the northerly direction of ice flow in the Riereach Burn area, with S2 dipping at a moderate angle $\left(30^{\circ}\right.$ to $\left.50^{\circ}\right)$ in an up-ice direction.

In all three samples, arcuate grain alignments and turbate structures are present throughout the thin section (Figures 19, 20 and 21). These rotational structures are, however, only developed/preserved within the microlithons between S1 and S2, indicating that clast rotation in general predated the imposition of the microfabrics within the till. Tiling or imbrication of sand to pebble sized clasts has also been recognised within the till (see Figures 19 and 21) with the long axes of the clasts dipping towards the north, i.e. in a down ice direction. In samples N7129 and N7132 the granule and pebble sized rock fragments do not show an obvious single preferred alignment. However, in sample N7128, as noted above, these large clasts exhibit a preferred shape-alignment parallel to S1, indicating that: (i) rotation of the larger clasts locally continued during the early stages of imposition of S1; or (ii) that the alignment of the larger clasts occurred prior to the imposition of S1 within the matrix of the till, with this pre-existing fabric controlling the orientation of the developing S1 fabric; and/or (iii) the orientation of stress regime responsible for the earlier alignment of the pebbles was maintained during later clast microfabric development.

Discussion and interpretation: It is clear from the results of the microstructural mapping of the thin sections of the subglacial traction till from Riereach Burn (Figures 19, 20 and 21) and Dalcharn (Figure 2) that they exhibit a number of marked similarities in terms of their response to subglacial deformation. These are:

- Microstructures typically equated with the rotation of the granule to pebble sized clasts are typically preserved within the microlithons of the clast microfabrics and that this rotational deformation occurred prior to foliation development within the matrix of the till;

- Clast microfabric development is highly heterogeneous with lithological variations within the till locally influencing the relative intensity and orientation (c.f. cleavage refraction) of these fabrics;

- Three successive generations of clast microfabric have been identified within the tills. The earliest of these, a heterogeneously developed S1 fabric dips down-ice and is variable in its intensity. This early fabric is either folded (F2), and either cross-cut or crenulated by a second, typically more pervasive (S2) microfabric which dips in an up-ice direction and occurs axial planar to the larger scale folds (were developed). The later, S3, microfabric is highly 
heterogeneous, potentially reflecting the partitioning of deformation into increasingly narrower zones of shear during the later stages of subglacial deformation;

- The spacing of the microfabric domains developed within the matrix of the till is controlled by the overall grain size of the diamicton and distribution of coarser grained clasts which acted as rigid, relatively immobile bodies during foliation development.

- Arcuate grain alignments and more complete turbate structures are preserved within the microlithons between S1 and S2, and locally appear to be truncated against the fabric domains defining these foliations. These relationships indicate that these rotational deformation leading to the developed of these structures occurred prior to the imposition of the clast microfabrics.

The similarities in the morphology and relationships between the successive generations of microfabrics and related microstructures present within the Riereach Burn and Dalcharn tills indicate that there are a number of common processes occurring during subglacial deformation. Figure 22 is a cartoon showing the possible microfabric relationships developed in a subglacial traction till in response to polyphase subglacial deformation based upon the microstructural maps constructed for the thin sections from the Riereach Burn and Dalcharn tills. At some point during subglacial deformation the till changes from a highly dilated, water-saturated sediment, in which any shear imposed by the overriding ice is accommodated by viscous flow, through to a much stiffer deposit capable of undergoing solid-state deformation; i.e. folding, fabric development, faulting. Preliminary results from the Scottish subglacial tills indicates that it is during this transition that clast microfabric development commences within the matrix of the diamicton.

The earliest microstructures preserved within the Scottish examples are the arcuate grain alignments and turbate structures (see Figure 22) equated with the rotational deformation within the water saturated till. The dilated nature of the till at this stage would have allowed the 'free rotation' (i.e. through angles $>360^{\circ}$ ) of even the larger clasts allowing them to become variably 'coated' or 'armoured' with finer grained matrix, and the development of the classic turbate structure described by van der Meer (1993, 1997). However, as the till dewaters and its dilation begins to fall, the corresponding decrease in separation between the pebbles within clast-rich diamictons and increasing stiffness of the matrix leads to these larger clasts becoming 'locked' in position. It is at this stage that clast microfabric development commences, as continued shearing imposed on the till by the overriding ice is taken up by the onset of deformation within its matrix. Evans et al. (2006) suggested that as the till begins to dewater an interconnecting framework begins to form within the matrix (the so called till-matrix framework of Evans et al., 2006) and it is the collapse and deformation of this framework that leads to fabric development within the till. Evidence from the Riereach Burn and Dalcharn tills indicates that the first (S1) microfabric to form dips down-ice (Figure 22), and formed by the passive rotation of sand-grade detritus into the plane of the developing foliation. During the initial stages of this deformation the till will still possess a relatively elevated pore water content and/or pressure. Consequently, stresses being applied to the deforming till matrix resulting in the heterogeneous collapse of the till-matrix framework, may also lead to localised 
liquefaction and renewed dilation of the diamicton. This could result in the loss or partial overprinting of the recently formed S1 microfabric, effectively resetting microfabric development/deformation within parts of the till. Small-scale pressure variations within the deforming bed may result in the remobilisation of the liquefied till, which would be 'squeezed out' of relatively higher pressure areas where the tillmatrix frame work is collapsing and clast microfabric development is well underway, and injected into lower strain areas to form cross-cutting veinlets and/or patches of massive till. This process is analogous to the collapse of the primary crystal framework and foliation development in the Glas Bheinn appinite during the forceful emplacement of this dioritic intrusion and described by Phillips \& May (1996) (compare Figure 22 with Figures 8 and 9). The stratification/layering present in samples N7126 (Figure 2) and N7128 (Figure 19) may have developed in response to the injection of remobilised till during the earlier stages of subglacial deformation, potentially explaining the marked variation in the intensity of S1 within different areas of these samples (compare S1 fabric strength in areas 1 and 4, with that in areas 5, 2 and 3 on Figure 22). On a large scale, this process of till 'collapse', liquefaction and remobilisation during subglacial deformation (Hiemstra \& van der Meer 1997) may provide a potential mechanism for driving a shifting pattern of sticky spots within the deforming bed (van der Meer et al., 2003; Piotrowski et al., 2004). The stiffening or hardening of areas of the till during deformation would lead to the development of slower moving sticky spots within the deforming bed. Migration of pulses of liquefied till into lower strain areas would increase the dilation and mobility of the till in this area, leading to an accompanying decrease in basal friction and therefore facilitating relatively faster movement of the overriding ice. The potential for the localised remobilisation and migration of pockets of dilated till within the deforming bed also provides a mechanism for 'filling' developing subglacial landforms such as the small-scale flutes developed beneath the oscillating margin of the Turtmann Glacier (van der Meer 1997).

Evidence from the Scottish tills indicates that as subglacial deformation continues the early formed fabric(s) may become progressively folded with this ductile deformation being accompanied by the development of a more pervasive second (S2) microfabric (S2) (Figure 22). This fabric has been found to be developed throughout the till suggesting that by this stage of the deformation history the tills may have dewatered sufficiently to restrict/retard further deformation induced liquefaction without a either significant increase in water content and/or strain. The spacing of the developing clast microfabrics within the matrix of the till is controlled by the overall grain size of the diamicton. For example, in the finer grained areas of sample N7128, S2 is closely spaced leading to an apparent increase in the relative intensity of the microfabric in this area (Figure 19). Consequently, extreme care must be taken if attempting to use the spacing of microfabrics as a proxy for the intensity of deformation recorded by the till. The imposition of S3 accompanied the later stages of deformation recorded by the Riereach Burn and Dalcharn tills. By this stage, the tills appear to have dewatered to such an extent that subglacial deformation began to 'lock up' with shearing being focused into narrow zones of ductile shear (see Figure 22). Furthermore, grain rotation would have become increasingly difficult within the rapidly stiffening till, leading to the switching off of clast microfabric development. It is possibly at this stage in the deformation history that discrete shears and small-scale brittle faults develop within the matrix of the till. This would herald a change from predominantly ductile to more brittle deformation within the bed of the glacier/ice sheet. 


\section{Conclusions}

The proposed 'microstructural mapping' method potentially represents a powerful new tool for the identification, description and analysis of the microstructures and clast microfabrics developed in polydeformed glacial sediments. The detailed microstructural maps of thin sections generated by this approach allow the relationships between successive generations of clast microfabrics and other microstructures (e.g. plasmic fabrics, turbate structures, folds, faults, shears...etc) to be determined, allowing a detailed relative chronology of fabric development to be established. This level of micromorphological detail is necessary when attempting to unravel the often complex polyphase deformation histories recorded by glacigenic deposits. Although the initial results, presented here, provide new insights into the processes occurring during glacitectonic deformation, the applicability of this approach to the analysis of diamictons from a range of both modern and former glacial environments does require further testing. The three case studies highlight the potential of this approach to our understanding of the processes occurring in the deformation of glacial sediments. The microstructures described must relate to the final deformation of the tills before being cleared by the ice, the related processes and sequences may prove to be typical of the deformation undergone by tills before this final stage. After all, variable levels of porewater content and/or pressure are standard in temperate subglacial conditions and these variations will trigger sequences as described here. Furthermore these examples show that, in case there was still any doubt, subglacial tills do not retain any evidence of their mode of deposition.

\section{Acknowledgements}

This publication stems from work carried out by ERP as part of the British Geological Survey's physical properties of UK tills project. Helen Reeves, John Lee, Simon Carr, Heather Channon, Clive Auton, Martin Gillespie and David Vaughn-Hirsch and the participants of the annual micromorphology symposiums held at Queen Mary (2009) and Royal Holloway (2010) are all thanked for their comments and discussions. John Fletcher (BGS, Keyworth), David Oates (BGS, Keyworth), Cees Zeegers (University of Amsterdam) and Adrian Palmer (Royal Holloway, University of London) are thanked for their expertise in making the thin sections. John Menzies and John Hiemstra are both thanked for their highly constructive reviews. ERP publishes with the permission of the Executive Director, British Geological Survey (National Environmental Research Council).

\section{References}

Auton, C.A., Firth, C.R., Merritt, J.W., 1990. Beauly to Nairn: Field Guide. Quaternary Research Association. pp 149.

Baroni, C., Fasano, F., 2006. Micromorphological evidence of warm-based glacier deposition from the Ricker Hills Tillite (Victoria Land, Antarctica). Quaternary Science Reviews. 25, 976-992.

Benn, D.I., Evans, D.J.A., 1998. Glaciers and Glaciation. Arnold, London.

Bell, T.H., Rubenach, M.J., 1983. Sequential porphyroblast growth and crenulation cleavage development during progressive deformation. Tectonophysics. 92, 171 - 94. 
Boulton, G.S., Dent, D.L., Morris, E.M., 1974. Subglacial shearing and crushing, and the role of water pressures in tills from south-east Iceland. Geografiska Annaler. 56A, 135-145.

Boulton, G.S., Hindmarsh, R.C.A., 1987. Sediment deformation beneath glaciers: rheology and geological consequences. Journal of Geophysical Research. 92, 90599082.

Boulton, G.S., van der Meer, J.J.M., Hart, J., Beets, D., Ruegg, G.H.J., van der Wateren, F.M., Jarvis, J. 1996. Till and moraine emplacement in a deforming bed surge - an example from a marine environment. Quaternary Science Reviews. 15, 961-987.

Boulton, G.S., van der Meer, J.J.M., Beets, D.J., Hart, K.J., Ruegg, G.H.J., 1999. The sediments and structural evolution of a recent push moraine complex, Holmstrømbreen, Spitsbergen. Quaternary Science Reviews. 18, 339-371.

Carr, S.J., 2001. Micromorphological criteria for distinguishing subglacial and glacimarine sediments: evidence from a contemporary tidewater glacier, Spitsbergen. Quaternary International. 86, 71-79.

Carr, S.J., 2004. Micro-scale features and structures. In: D.J.A. Evans, D.I. Benn (eds.), A practical guide to the study of glacial sediments. Arnold, London, pp. 115144.

Carr, S.J., Haflidason, H., Sejrup, H.P., 2000. Micromorphological evidence supporting late Weichselian glaciation of the northern North Sea. Boreas. 29, 315328.

Carr, S.J., Holmes, R., van der Meer, J.J.M., Rose, J., 2006. The last glacial maximum in the North Sea basin: Micromorphological evidence of extensive glaciation. Journal of Quaternary Science. 21, 131-153.

Carr, S.J., Goddard, M., 2007. Role of particle-size in the development of till fabric: implications for using eigenvectors in understanding glacier dynamics. Boreas. 36, 371-385.

Choukroune, P., Gapais, D., Merle, O., 1987. Shear criteria and structural symmetry. Journal of Structural Geology. 9, 525-530.

Denis, M., Guiraud, M., Konaté, M., Buoncristiani, J.-F. 2010. Subglacial deformation and water-pressure cycles as a key for understanding ice stream dynamics: evidence from the Late Ordovician succession of the Djado Basin (Niger). International Journal of Earth Science (Geol Rundsch). 99, 1399-1425.

Evans, D.J., Phillips, E.R., Hiemstra, J.F., Auton, C.A., 2006. Subglacial till: formation, sedimentary characteristics and classification. Earth-Science Reviews. 78, 115-176. 
Evenson, E.B., 1970. A method for 3-dimensional microfabrics analysis of tills obtained from exposures or cores. Journal of Sedimentary Petrology. 40, 762-764.

Evenson, E.B., 1971. The relationship of macro- to microfabrics of tills and the genesis of glacial landforms in Jefferson County, Wisconsin. In R.P. Goldthwait (ed.), Till, a Symposium. Ohio State University Press, 345-364.

Fletcher, T.P., Auton, C.A., Highton, A.J., Merritt, J.W., Robertson, S., Rollin, K.E., 1996. Geology of Fortrose and eastern Inverness district. Memoir of the British Geological Survey, Sheet 84W (Scotland). London: HMSO.

Harris, C., 1998. The micromorphology of paraglacial and periglacial slope deposits: a case study from Morfa Bychan, west Wales, UK. Journal of Quaternary Science. 13, 73-84.

Hart, J.K., Khatwa, A., Sammonds, P., 2004. The effect of grain texture on the occurrence of microstructural properties in subglacial till. Quaternary Science Reviews, 23, 2501-2512.

Hart, J.K., 2007. An investigation of subglacial shear zone processes from Weybourne, Norfolk, UK. Quaternary Science Reviews. 26, 2354-2374.

Hart, J., Rose, J., 2001. Approaches to the study of glacier bed deformation. Quaternary International. 86, 45-58.

Hiemstra, J.F., van der Meer, J.J.M., 1997. Pore-water controlled grain fracturing as an indicator for subglacial shearing in tills. Journal of Glaciology. 43, 446-454.

Hiemstra, J.F., Rijsdijk, K.F., 2003. Observing artificially induced strain: implications for subglacial deformation. Journal of Quaternary Science. 18, 373-383.

Hiemstra, J.F., Rijsdijk, K.F., Evans, D.J.A., van der Meer, J.J.M., 2005. Integrated micro- and macro-scale analyses of Last Glacial maximum Irish Sea diamicts from Abermaw and Treath y Mwnt, Wales, UK. Boreas. 34, 61-74.

Iverson, N.R., Hoojer, T.S., Hooke, R. LeB., 1996. A laboratory study of sediment deformation: stress heterogeneity and grain-size evolution. Annals of Glaciology. 22, $167-175$

Key, R.M., Phillips, E.R., Chacksfield, B.C., 1993. Emplacement and thermal metamorphism associated with the post-orogenic Strath Ossian Pluton, Grampian Highlands, Scotland. Geological Magazine, 130, 379-390.

Khatwa, A., Tulaczyk, S., 2001. Microstructural interpretations of modern and Pleistocene subglacially deformed sediments: the relative role of parent material and subglacial processes. Journal of Quaternary Science. 16, 507-517.

Kilfeather, A.A., van der Meer, J.J.M., 2007. Pore size, shape and connectivity in tills and their relationship to deformation processes. Quaternary Science Reviews. 27, 250266. 
Kilfeather, A.A., Ó Cofaigh, C., Dowdeswell, J.A., Meer, J.J.M. van der, Evans, D.J.A., 2010. Micromorphological characteristics of glacimarine sediments: implications for distinguishing genetic processes of massive diamicts. Geo-Marine Letters. 30, 77-97.

Lachniet, M.S., Larson, G.J., Strasser, J.C., Lawson, D.E., Evenson, E.B., 1999. Microstructures of glacigenic sediment flow deposits, Matanuska Glacier, Alaska. In Mickleson, D.M., Attig, J.W. (Eds). Glacial Processes Past and Present. Geological Society of America, Special Paper. 337, Boulder, CO.

Lachniet, M.S., Larson, G.J., Lawson, D.E. Evenson, E.B., Alley, R.B., 2001. Microstructures of sediment flow deposits and subglacial sediments: a comparison. Boreas. 30, 254-262.

Larsen, N.K., Piotrowski, J.A., Christiansen, F., 2006. Microstructures and microshears as proxy for strain in subglacial diamicts: implications for basal till formation. Geology. 34, 889-892.

Larsen, N.K., Piotrowski, J.A., Menzies, J., 2007. Microstructural evidence of lowstrain, time transgressive subglacial deformation. Journal of Quaternary Science. 22, 593-608.

Lee, J.R., Phillips, E.R., 2008. Progressive soft sediment deformation within a subglacial shear zone - a hybrid mosaic-pervasive deformation model for Middle Pleistocene glaciotectonised sediments from eastern England. Quaternary Science Reviews. 27, 1350-1362.

Menzies, J., Maltman, A.J., 1992. Microstructures in diamictons - evidence of subglacial bed conditions. Geomorphology. 6, 27-40.

Menzies, J., Zaniewski, K., Dreger, D., 1997. Evidence from microstructures of deformable bed conditions within drumlins, Chimney Bluffs, New York State. Sedimentary Geology. 111, 161-175.

Menzies, J., van der Meer, J.J.M., 1998. Sedimentological and micromorphological examination of a late Devensian multiple diamicton sequence near Moneydie, Perthshire, east-central Scotland. Scottish Journal of Geology. 34, 15-21.

Menzies, J., 2000. Microstructures in diamictites of the lower Gowganda Formation (Huronian), near Elliot Lake, Ontario: evidence for deforming-bed conditions at the grounding line ? Journal of Sedimentary Research. 70, 210-216.

Menzies, J., 2000. Micromorphological analyses of microfabrics and microstructures indicative of deformation processes in glacial sediments. In A.J. Maltman, B. Hubbard, M.J. Hambrey (eds.) Deformation of glacial materials. Geological Society of London, Special Publication. 176, 245-257. 
Menzies, J., Zaniewski, K., 2003. Microstructures within a modern debris flow deposit derived from Quaternary glacial diamicton - a comparative micromorphological study. Sedimentary Geology. 157, 31-48.

Menzies, J., Taylor, J.M., 2003. Seismically induced soft-sediment microstructures (seismites) from Meileour, western Strathmore, Scotland. Boreas. 32, 314-327.

Menzies, J., van der Meer, J.J.M., Rose, J., 2006. Till - a glacial "tectomict", a microscopic examination of a till's internal architecture. Geomorphology. 75, 172200.

Menzies, J., Brand, U., 2007. The internal sediment architecture of a drumlin, Port Byron, New York State, USA. Quaternary Science Reviews. 26, 322-335.

Menzies, J., Whiteman, C., 2009. A comparative analyses of microstructures from Late Jurassic diamictic units, near Helmsdale, northeast Scotland and a Pleistocene diamicton from Milton, southern Ontario, Canada - a differential diagnostic method of sediment typing using micromorphology. Netherlands Journal of Geosciences, Geologie en Mijnbouw. 88, 75-94.

Passchier, C.W., Trouw, R.A.J. 1996. Microtectonics. Springer.

Palmer, A.P., Rose, J., Lowe, J.J., MacLeod, A., 2010. Annually resolved events of Younger Dryas glaciation in Lochaber (Glen Roy and Glen Spean), Western Scottish Highlands. Journal of Quaternary Science. 25, 581-596.

Phillips, E.R., Merritt, J., 2008. Evidence for multiphase water-escape during rafting of shelly marine sediments at Clava, Inverness-shire, NE Scotland. Quaternary Science Reviews. 27, 988-1011.

Phillips, E.R., Auton, C.A., 2008. Microtextual analysis of a glacially 'deformed' bedrock: implications for inheritance of preferred clast orientations in diamictons. Journal of Quaternary Science. 23, 229-240.

Phillips, E.R., Merritt, J.W., Auton, C.A., Golledge, N.R., 2007. Microstructures developed in subglacially and proglacially deformed sediments: faults, folds and fabrics, and the influence of water on the style of deformation. Quaternary Science Reviews. 26, 1499-1528.

Phillips, E.R., 2006. Micromorphology of a debris flow deposit: evidence of basal shearing, hydrofracturing, liquefaction and rotational deformation during emplacement. Quaternary Science Reviews. 25, 720-738.

Phillips, E.R., Auton, C.A., 2000. Micromorphological evidence for polyphase deformation of glaciolacustrine sediments from Strathspey, Scotland. In Maltman, A.J., Hubbard, B., Hambrey, M.J. (eds.) Deformation of glacial materials. The Geological Society of London, Special Publication. 176, 279-291. 
Phillips, E.R., Auton, C.A., 1997. Ductile fault rocks and metamorphic zonation in the Dalradian of the Highland Border SW of Stonehaven, Kincardineshire. Scottish Journal of Geology. 33, 83-93.

Phillips, E.R., May, F., 1996. The Glas Bheinn Appinitic Complex, Glen Roy: a model for foliation development during emplacement. Scottish Journal of Geology. 32, 9-22.

Phillips, E.R., Barnes, R.P., Boland, M.P., Fortey, N.J., McMillan A.A., 1995. The Moniaive Shear Zone: a major zone of sinistral strike-slip deformation in the Southern Uplands of Scotland. Scottish Journal of Geology. 31, 139-150.

Phillips, E.R., Key, R.M., Clark, G.C., May, F., Chacksfield, B.C., Glover, B.W., 1994. Tectonothermal evolution of the Neoproterozoic Grampian and Appin Groups, southwestern Monadhliath Mountains, Scotland. Journal of the Geological Society of London. 151, 971-986.

Phillips, E.R., Clark, G.C., Smith, D.I., 1993. Mineralogy, petrology and microfabric analysis of the Eilrig Shear Zone, Fort Augustus. Scottish Journal of Geology. 29, 143-158.

Phillips, E.R., Key, R.M., 1992. Porphyroblast-fabric relationships: an example from the Appin Group in the Glen Roy area. Scottish Journal of Geology. 28, 89-101.

Piotrowski, J.A., Larsen, N.K., Junge, F., 2004. Soft subglacial beds: a mosaic of deforming and stable spots. Quaternary Science Reviews. 23, 993-1000.

Powell, C.M.A. 1979. A morphological classification of rock cleavage. Tectonophysics. 58, 21-34.

Reinardy, B.T.I., Lukas, S., 2009. The sedimentary signature of ice-contact sedimentation and deformation at macro- and micro-scale: A case study from NW Scotland. Sedimentary Geology. 221, 87-98.

Roberts, D.H., Hart, J.K., 2005. The deforming bed characteristics of a stratified till assemblage in north East Anglia, UK: investigating controls on sediment rheology and strain signatures. Quaternary Science Reviews. 24, 123-140.

Seret, G., 1993. Microstructures in thin sections of several kinds of till. Quaternary International. 18, 97-101.

Thomason, J.F., Iverson, N.R., 2006 Microfabric and micro-shear evolution in deformed till. Quaternary Science Reviews. 25, 1027-1038.

Thomason, J.F., Iverson, N.R., 2009. Deformation of the Batestown till of the Lake Michigan lobe, Laurentide ice sheet. Journal of Glaciology. 55, 131-146.

van der Meer, J.J.M., Rappol, M., Semeyn, J.N., 1983. Micromorphological and preliminary X-ray observations on a basal till from Lunteren, The Netherlands. Acta Geologica Hispanica. 18, 199-205. 
van der Meer, J.J.M., Rappol, M., Semeyn, J.N., 1985. Sedimentology and genesis of glacial deposits in the Goudsberg, Central Netherlands. Mededelingen van de Rijks Geologische Dienst. 39-2, 1-29.

van der Meer, J.J.M., 1987. Micromorphology of glacial sediments as a tool in distinguishing genetic varieties of till. Geological Survey of Finland Special Paper 3, 77-89.

van der Meer, J.J.M., Laban, C., 1990. Micromorphology of some North Sea till samples, a pilot study. Journal of Quaternary Science. 5, 95-101.

van der Meer, J.J.M., Rabassa, J.O., Evenson, E.B., 1991. Micromorphological aspects of glaciolacustrine sediments in northern Patagonia, Argentina. Journal of Quaternary Science. 7, 31-44.

van der Meer, J.J.M., 1993. Microscopic evidence of subglacial deformation. Quaternary Science Reviews. 12, 553-587.

van der Meer, J.J.M., Verbers, A.L.L.M., Warren, W.P., 1994. The micromorphological character of the Ballycroneen Formation (Irish Sea Till): a first assessment. In Warren, W.P., Croot, D.G. (eds.) Formation and deformation of glacial deposits. Balkema, Rotterdam, pp. 39-49.

van der Meer, J.J.M., 1997, Particle and aggregate mobility in till: microscopic evidence of subglacial processes. Quaternary Science Reviews. 16, 827-831.

van der Meer, J.J.M., Warren, W.P., 1997. Sedimentology of late glacial clays in lacustrine basins, Central Ireland. Quaternary Science Reviews. 16, 779-791.

van der Meer, J.J.M., Menzies, J., Rose, J., 2003. Subglacial till, the deformable glacier bed. Quaternary Science Reviews. 22, 1659-1685.

van der Meer, J.J.M., Kjær, K.H., Krüger, J., Rabassa, J., Kilfeather, A.A., 2009. Under pressure: clastic dykes in glacial settings. Quaternary Science Reviews. 28, 708-720.

van der Wateren, F.M., 1999. Structural geology and sedimentology of the Heiligenhafen till section, Northern Germany. Quaternary Science Reviews. 18, 16251639.

van der Wateren, F.M., Kluiving, S.J., Bartek, L.R., 2000. Kinematic indicators of subglacial shearing. In: A.J. Maltman, B. Hubbard, M.J. Hambrey (eds.) Deformation of glacial materials. Geological Society of London, Special Publication. 176, 259-278.

Walker, M.J.C., Merritt, J.W., Auton, C.A., Coope, G.R., Field, M.H., Heijnis, H. A., Taylor, B.J., 1992. Allt Odhar and Dalcharn: two pre-Late Devensian/Late Weichselian sites in northern Scotland. Journal of Quaternary Science. 7, 69-86.

\section{Figures}


Figure 1. Diagram showing the five stages involved in the proposed graphical approach to the identification and analysis of clast microfabrics in glacial sediments: Stage 1 - import high resolution scan of thin section into graphics package; Stage 2 measure the orientation of the long axes of the clasts; Stage 3 - plot orientation data on a rose diagram; Stage 4 - identification of main clast microfabrics; and Stage 5 identification of clast microfabric domains and final interpretation of clast microfabrics.

Figure 2. Example of a completed microstructural map of a polydeformed, sandstonerich subglacial traction till (sample N7126), the Dalcharn Lower Till, exposed in a river section at Dalcharn West [NH 8144 4528], NE Scotland (see text for details).

Figure 3. Example of a completed microstructural map of polydeformed, thinly laminated sand silt and clay overlain by subglacial traction till (sample S98556) from Raitts Burn [NH 796 036], Strathspey, Scotland (see text for details).

Figure 4. Terminology proposed for the morphological description of clast microfabrics in glacial sediments. This non-genetic terminology is based upon the system used by petrologists for the description and classification of cleavage and/or schistosity developed in metamorphic rocks using a petrological microscope (after Powell 1979; Borradaile et al., 1982; Passchier \& Trouw 1996).

Figure 5. Examples of detailed clast microfabrics relationships developed in a sandy subglacial traction till from Riereach Burn, Scotland: (a) A spaced, discontinuous clast microfabric (S2) wrapping around a large, well-rounded clast of fine-grained sandstone with distinct 'pressure shadows' developed adjacent to this clast; (b) A spaced, discontinuous S2 microfabric with earlier formed arcuate grain alignments and crenulated S1 microfabric preserved within the intervening microlithons; (c) A closely spaced, discontinuous clast microfabric with arcuate grain alignments (turbate structures of van der Meer 1983) developed adjacent to, or enclosing granule to pebble sized clasts being preferentially preserved within the intervening microlithons; and (d) Crenulation-style microfolds deforming a closely spaced clast microfabric developed adjacent to a large, pebble sized clast of metasandstone. These microfolds may have developed in response to either (i) the focusing of shear adjacent to this rigid, relatively immobile clast, or (ii) localisation of deformation within the matrix immediately adjacent to the clast associated with the rotation of this pebble.

Figure 6. Photomicrographs showing examples of foliations developed in upper greenschist to amphibolite facies metamorphic rocks: (a) Poikiloblasts of garnet (black) wrapped by a well-developed schistosity within a amphibolite facies garnetbiotite-mica schist (Neoproterozoic Leven Schist, Glen Roy, Scotland; see Phillips and Key 1992) defined by alternating quartz (white to grey) and mica (predominantly muscovite, blue to yellow-green colour) domains; (b) Poikiloblast of garnet wrapped by a well-developed schistosity (defined by muscovite (pink to yellow-green) within a amphibolite facies garnet-biotite-mica schist (Neoproterozoic Leven Schist, Glen Roy, Scotland), note the presence of lenticular pressure shadows composed of quartz immediately adjacent to the garnet; (c) Rotated, 'snowball' garnet porphyroblast developed within a partially annealed, micaceous quartz mylonite (Eilrig Shear Zone, near Fort Augustus, Scotland; see Phillips et al., 1993); (d) Anhedral andalusite (pale 
grey) porphyroblast overgrowing an S2 crenulation cleavage within a contact metamorphosed garnet-biotite-mica-schist (Strath Ossian, Scotland). The andalusite developed as a result of thermal or contact metamorphism associated with the emplacement of the Strath Ossian granite pluton; see Key et al., 1993). Also note the development of a biotite (red-brown) reaction rim on the relict garnet porphyroblast due to the break down of this mineral during this contact metamorphic event; (e) Well-developed crenulation cleavage developed within a middle to upper greenschist facies chlorite-muscovite-schist (Neoproterozoic Southern Highlands Group, Scotland). The earlier S1 fabric defined by shape and optically aligned muscovite flakes (yellow) is deformed by a series of tight, angular microfolds which define the S2 fabric; and (f) Irregular, anhedral microcline porphyroblasts (blue grey) overgrowing a well-developed crenulation cleavage/schistosity developed within an upper greenschist to lower amphibolite facies microcline-muscovite-biotite-schist (Neoproterozoic Southern Highlands Group, Scotland). All photographs taken under crossed polarised light, scale bar $=1 \mathrm{~mm}$.

Figure 7. Photomicrographs showing examples of foliations developed within extrusive and intrusive igneous rocks, a mylonitised metasandstone and sheared subgreenschist facies metamorphosed wacke sandstones: (a) Aligned, lath-shaped plagioclase (colourless) phenocrysts defining a moderate to well-developed pilotaxitic (flow) fabric developed within a basaltic lava (Carboniferous, Clyde Plateau Lavas, Midland Valley, Scotland) (plane polarised light, scale bar $=1 \mathrm{~mm}$ ); (b) Aligned, anhedral to subhedral hornblende (brown) phenocrysts defining a well-developed pilotaxitic fabric developed within an andesitic high-level intrusion ('The Imperial Porphyry', locality unknown, Egypt) (plane polarised light, scale bar = $1 \mathrm{~mm}$ ); (c) Elongate, single quartz crystals aligned parallel to a well-developed mylonitic fabric present within a mylonitised metasandstone (Neoproterozoic, Southern Highland Group, SW of Stonehaven, Scotland; Phillips and Auton, 1997) (crossed polarised light, scale bar = $1 \mathrm{~mm}$ ); (d) and (e) Well-developed shear fabric developed within a highly deformed sub-greenschist facies wacke metasandstone from the Moniaive Shear Zone, SW Scotland (Phillips et al., 1995). Deformation has resulted in the variable rotation of detrital grains, the development of asymmetrical pressure shadows adjacent to these detrital grains, localised cataclasis (fracturing) of rigid quartz and feldspar grains and attenuation of softer mudstone intraclasts (plane polarised light, scale bar $=1 \mathrm{~mm})$.

Figure 8. Well-developed pre-full crystallisation fabrics developed within an appinitic quartz-diorite to granodiorite from the Glas Bheinn Appinitic Complex, Glen Roy (Phillips and May 1996). (a) Moderately developed domainal fabric defined by parallel to weakly anastomosing, discontinuous biotite-rich domains (brown) and variably shape-aligned amphibole (pale green) porphyroblasts. The intervening microlithons or feldspathic domains are richer in colourless quartz and feldspar (mainly plagioclase); (b) Well-developed, closely spaced, anastomosing pre-full crystallisation foliation defined by biotite domains wrapping around shape aligned subhedral to euhedral amphibole phenocrysts. Also note locally developed pressure shadows developed adjacent to the amphibole phenocrysts composed of unstrained quartz and feldspar; and (c) Closely spaced to locally continuous pre-full crystallisation fabric defined by shape-aligned biotite and amphibole. Note the more random orientation of the amphibole phenocrysts within the domain rich in felsic minerals (see text for details). Insets: rose diagrams showing the orientation of the 
main fabric(s) defined by the preferred alignment of the amphibole phenocrysts. All photographs taken in plane polarised light; scale bar $=5 \mathrm{~mm}$.

Figure 9. Diagram showing the progressive development of the pre-full crystallisation fabric within the appinitic quartz-diorite to granodiorite taken from Phillips and May (1996). (a) randomly orientated biotite and amphibole crystals forming an open crystals frame work within the slowly crystallising granitic melt; (b) On-set of foliation development resulting in the collapse of the crystal framework, passive rotation of biotite and amphibole crystals and migration of the residual melt into low pressure (feldspathic) domains; and (c) Total collapse of the crystal framework in the mafic domains resulting in the complete expulsion of the residual melt and the local development of a closely spaced to continuous pre-full crystallisation fabric within the biotite and amphibole-rich domains.

Figure 10. (a) Map showing the location of Dinas Dinlle, North Wales. (b) Photograph showing steeply inclined to subvertical faults (downthrow to the north) offsetting bedding within the sands and gravels exposed at the southern end of the larger northern section at Dinas Dinlle. Also shown is the location of sample DD09 $3 / 1$.

Figure 11. Microstructural map of a deformed (faulted) gravel (sample DD09 3/1) from Dinas Dinlle, Llyn Peninsula, North Wales. The gravel possesses a welldeveloped bedding-parallel clast microfabric which has been folded by an open, upright structure. This fold has been cut by a relatively later steeply inclined fault zone (see text for details).

Figure 12. Model for the progressive development of the normal fault present within gravel sample from Dinas Dinlle based upon the interpretation of the microstructural map completed for this thin section.

Figure 13. (a) Photograph of a small flute formed in the lee of a large boulder exposed in a portal during the 1986 annual retreat of the Turtmann Glacier, Switzerland; (b) Field sketch showing the location of the three samples of till taken from the flute; (c) Lower hemisphere stereographic projection showing the orientation of the dominant clast microfabrics identified in thin section. Also shown on the figure are the relationships of these microfabrics to the ice movement direction and orientation of the flute.

Figure 14. Microstructural map of a thin section of till (sample 0.831) taken parallel to the long axis of a flute exposed during the annual recession of the Turtmann Glacier, Switzerland. The till is lithological variable and is composed of two compositionally distinct diamictons. The main clast macrofabric present within the till is a pervasive, steeply inclined discontinuous microfabric comprising lenticular, irregular, weakly anastomosing domains that cut across an irregular lithological boundary present within this thin section.

Figure 15. Microstructural map of a horizontally orientated thin section of till (sample 0.832) from a flute, Turtmann Glacier, Switzerland. Two main clast macrofabrics have been identified within the till, the most pervasive is a 
discontinuous microfabric that cuts across an irregular lithological boundary present within this sample.

Figure 16. Microstructural map of a thin section of till (sample 0.833) taken across the long axis of a flute (orthogonal to sample 0.831), Turtmann Glacier, Switzerland. Two main clast macrofabrics can be recognised with the most pervasive of the two being a discontinuous (S2) microfabric. An apparently earlier (S1) microfabric is locally preserved within the microlithons of the main foliation. Also note that linear and arcuate grain alignments are only locally developed/preserved and, where present, occur within the microlithons of the main (S2) foliation.

Figure 17. Schematic 3D block diagram showing the relationships between the various microfabrics developed within the flute. Note that the boundary between the two lithologically distinct areas of diamicton is highly irregular and that the main clast microfabrics cut across this boundary.

Figure 18. (a) Map showing the location of the Riereach Burn area, NE Scotland; (b) Photograph showing the glacial sequence exposed in Riereach Burn. The sequence comprises sandy and silty tills interstratified with sands, overlain by outwash sand and gravel. (c) Clast-rich, gravelly looking subglacial traction till exposed in Riereach Burn cut by a thin sand-filled hydrofracture.

Figure 19. Microstructural map of sample N7128 showing the relationships between the clast microfabrics and spatially related microstructures (arcuate grain alignments...etc) developed within this Late Devensian subglacial traction till. Basal grey-brown metasandstone and granite-rich till exposed in Riereach Burn [NH 83903 43151], NE Scotland.

Figure 20. Microstructural map of sample N7129 showing the relationships between the clast microfabrics and spatially related microstructures (arcuate grain alignments...etc) developed within this Late Devensian subglacial traction till. Basal grey-brown metasandstone and granite-rich till, Riereach Burn [NH 83903 43151], NE Scotland.

Figure 21. Microstructural map of sample N7132 showing the relationships between the clast microfabrics and spatially related microstructures (arcuate grain alignments...etc) developed within this Late Devensian subglacial traction till. Basal grey-brown metasandstone and granite-rich till, Riereach Burn [NH 84503 44132], NE Scotland.

Figure 22. Cartoon showing the possible microfabric relationships developed in response to polyphase deformation during the formation of a subglacial traction till (see text for details). 


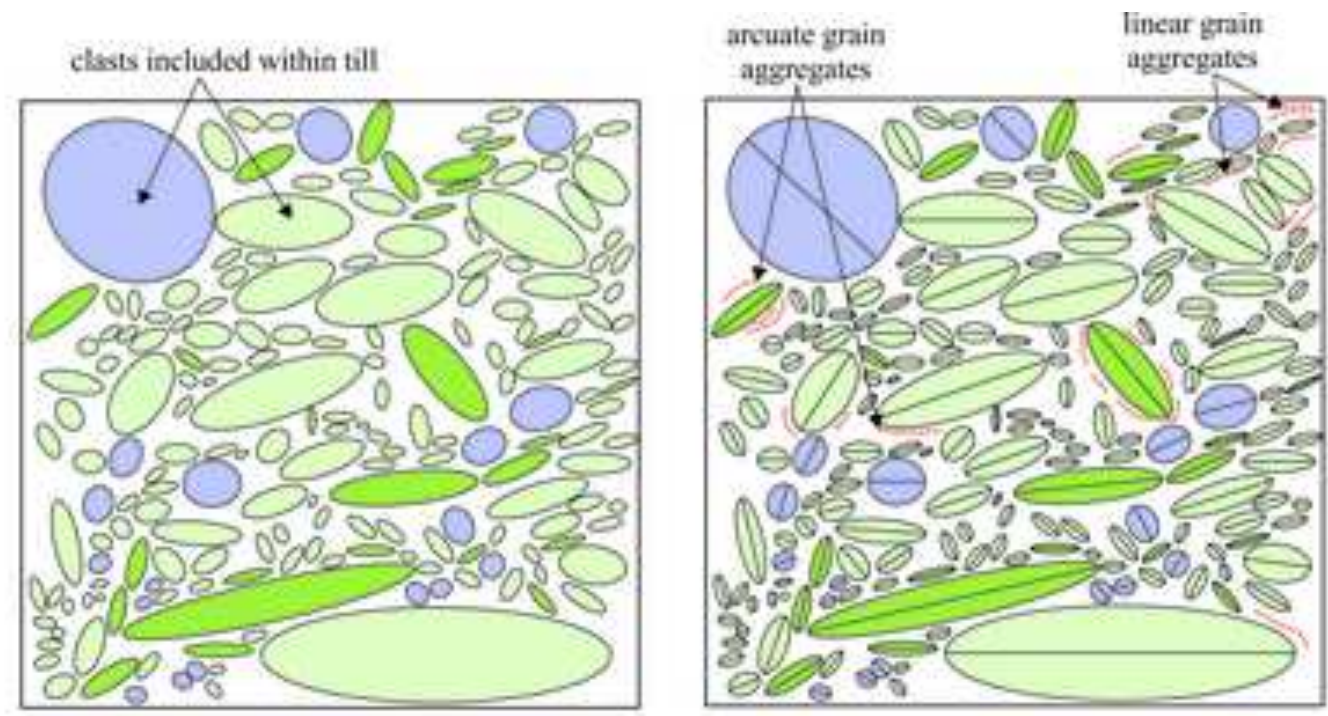

Stage I: bigh resolution scian of thin section

Stage 2: measure orientation of long axes of ctasts

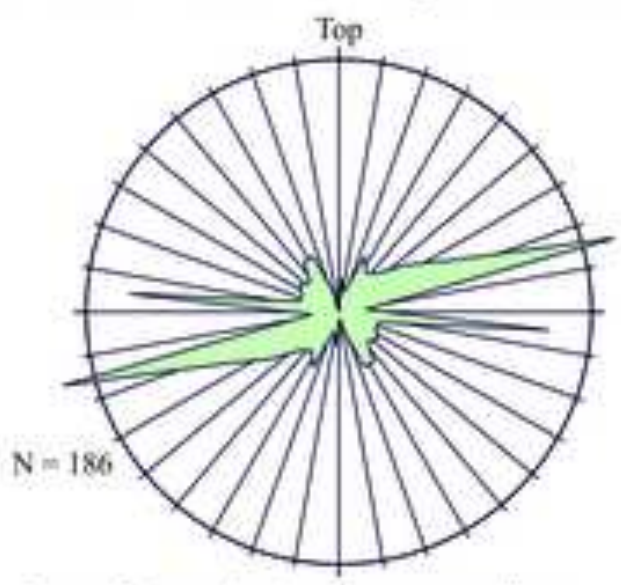

Stage 3: plot oricntatiou data on rose diagram

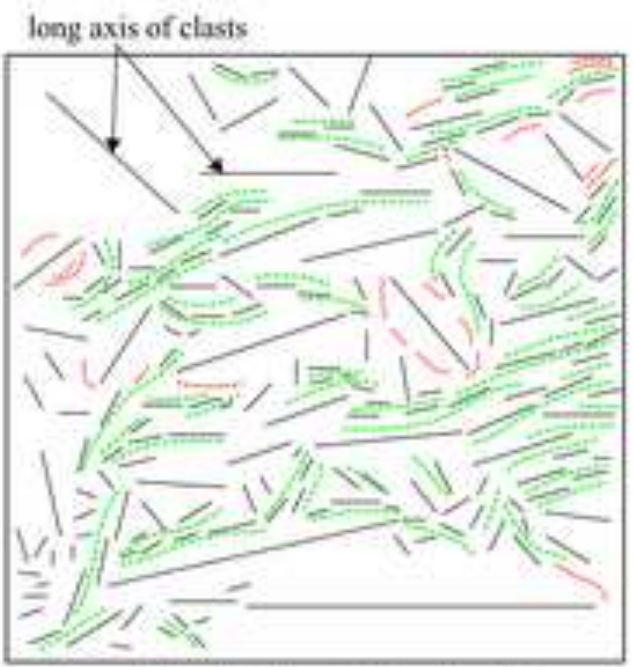

Stage 4: identification of main clast fabrics

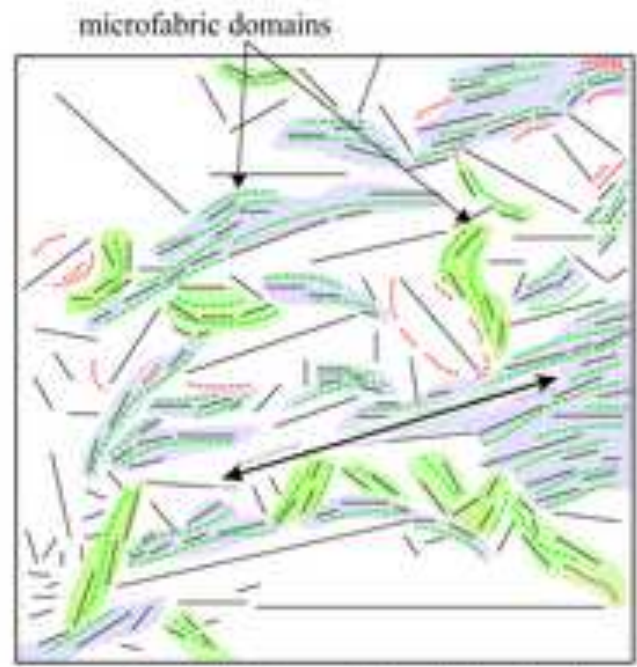

Stage 5: identification of clast fabric domains and final inserpretation of elast fabries

\footnotetext{
arcuate and linear grain aggregates $/$ long axis of clasts.

microfabric defincd by long axes of elasts $\longrightarrow$ orientation of main fabric(s)
}

Figure 1. Diagram showing the five stages involved in the proposed graphical approach to the identification and analysis of clast microfabrics in glacial sediments; Stage 1 - import high resolution scan of thin section into graphies package; Stage 2 - measure the orientation of the long axes of the clasts; Stage 3 -plot orientation data on a rose diagram; Stage 4 -identification of main clast microfabrics; and Stage 5 - identification of clast microfabric domains and final interpretation of clast microfabrics. 


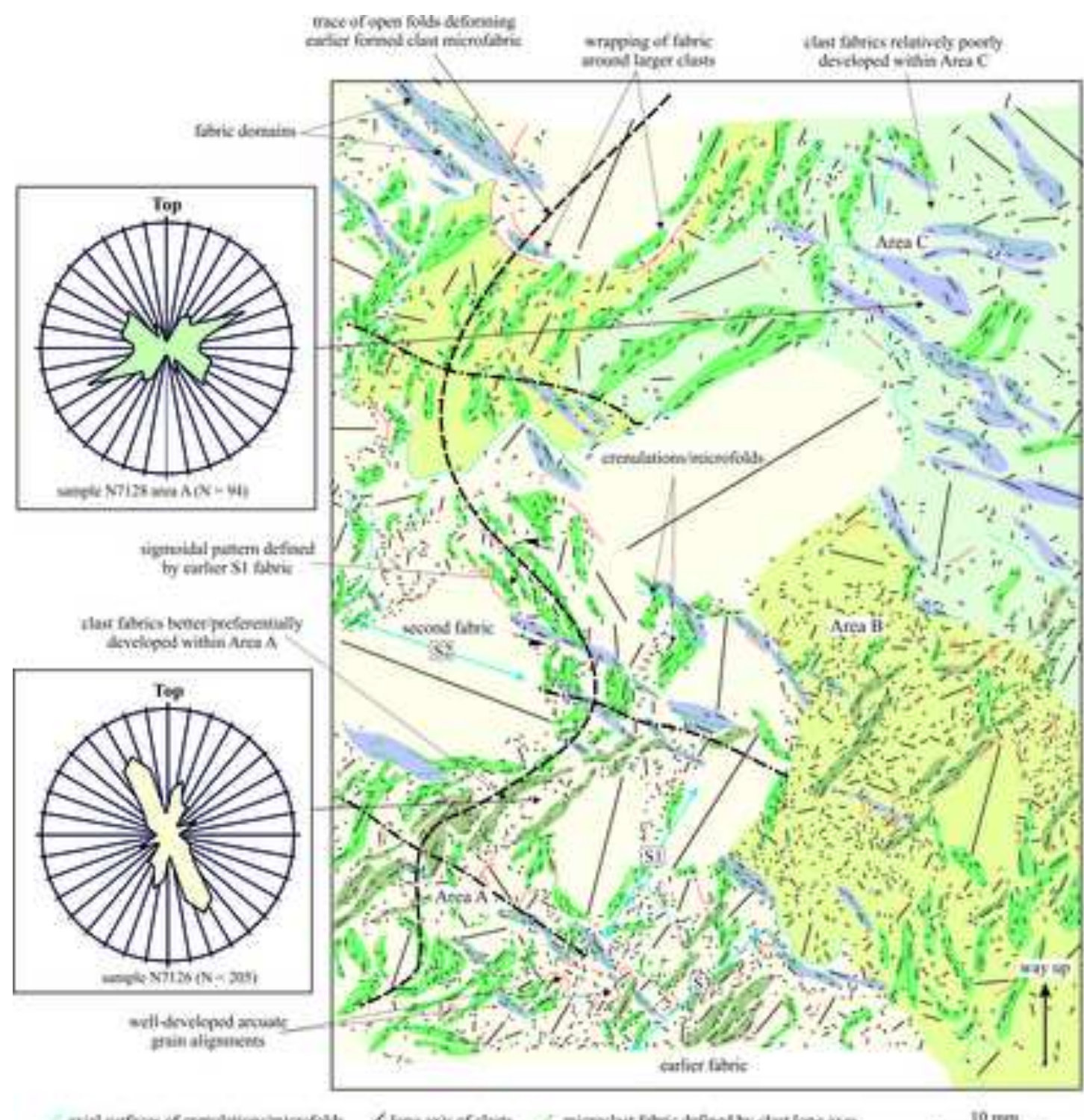

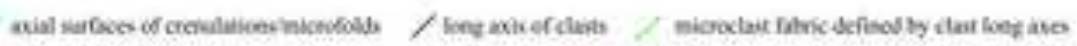

$10 \mathrm{~mm}$

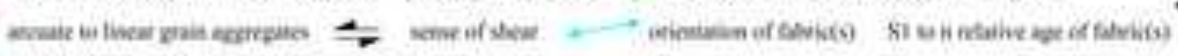

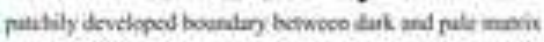

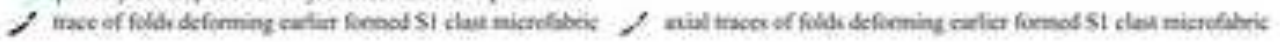

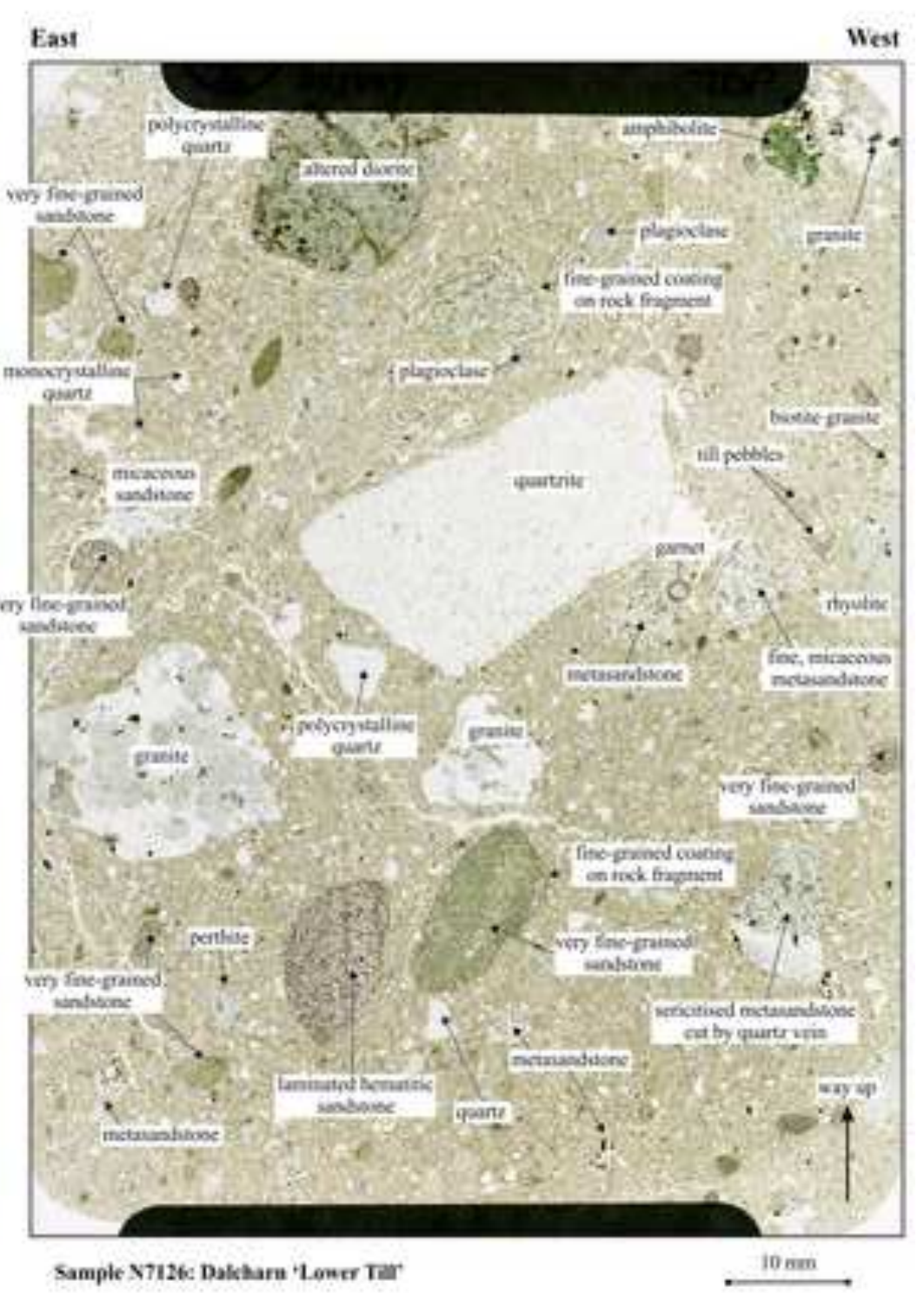

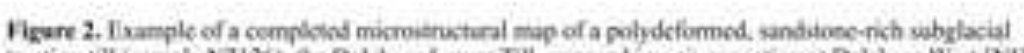

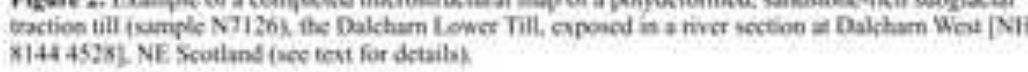


Click here to download high resolution image

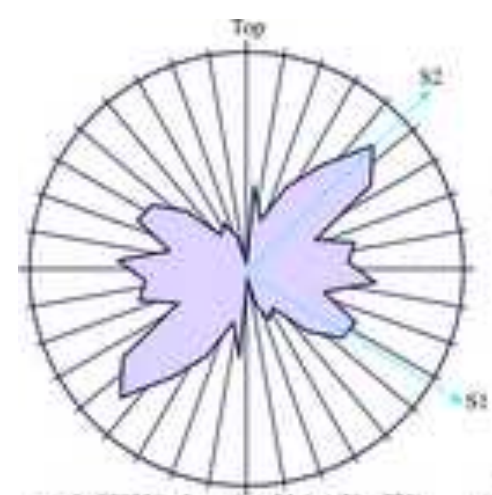

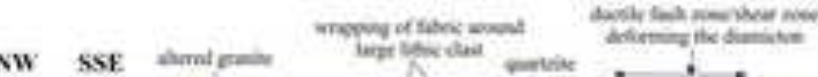
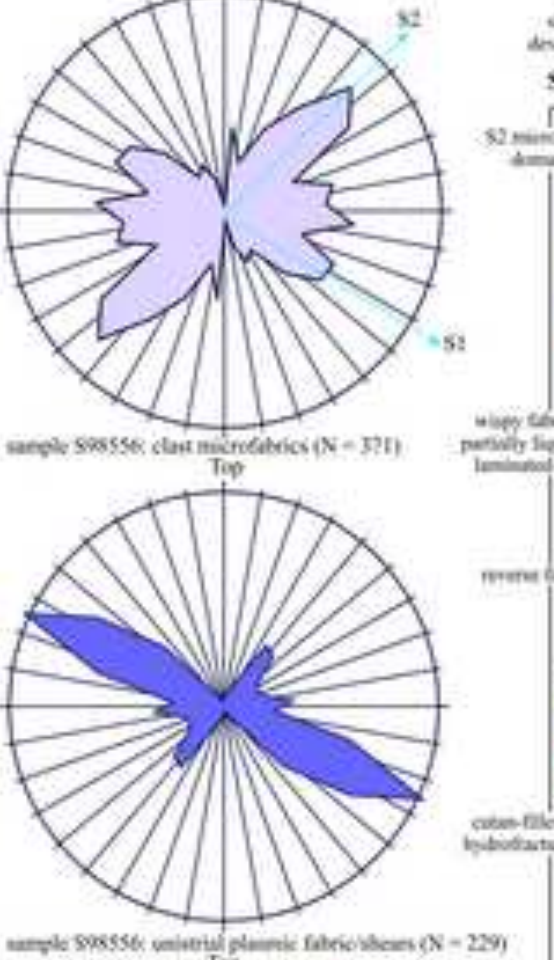

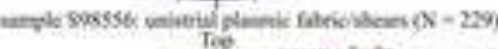

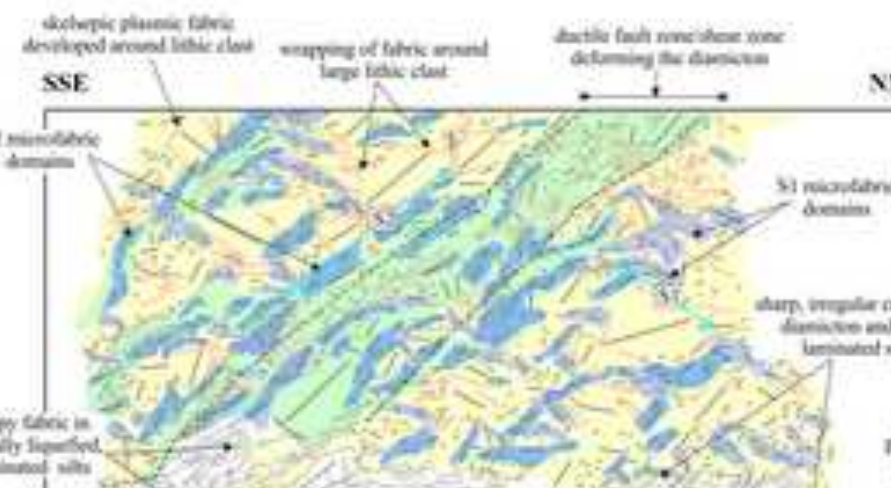

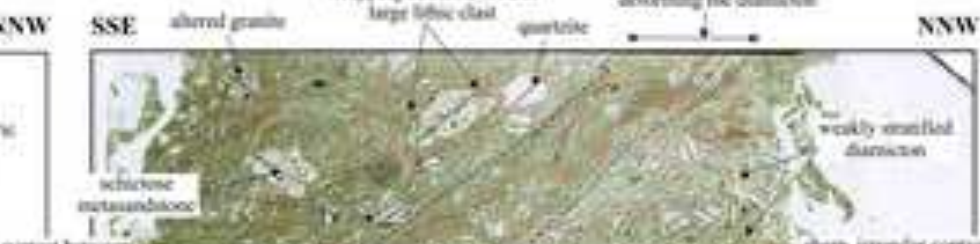

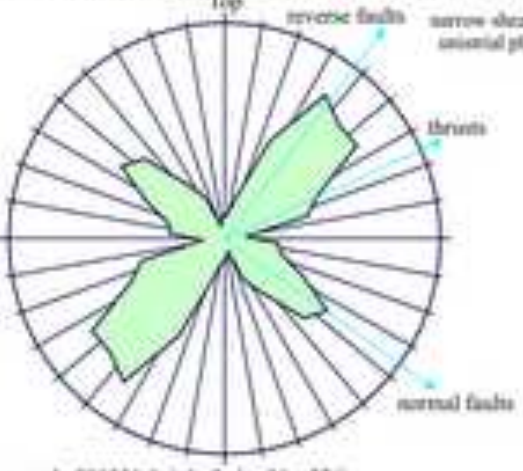

time

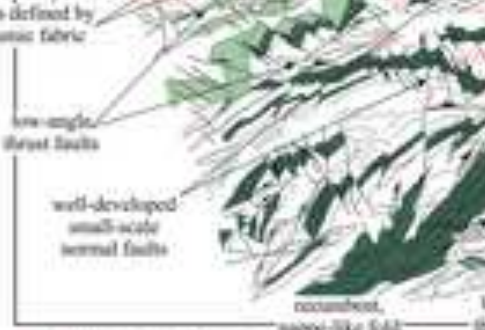

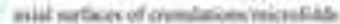

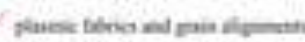

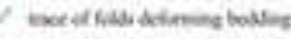

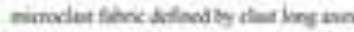

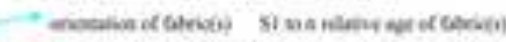

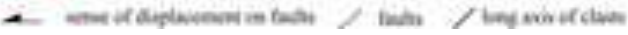

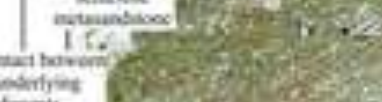

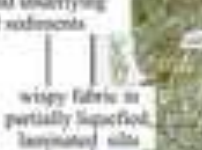

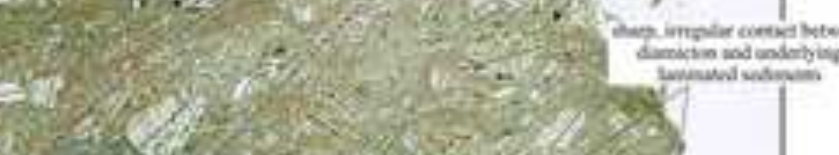

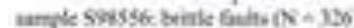

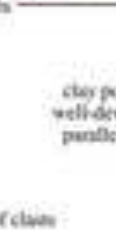

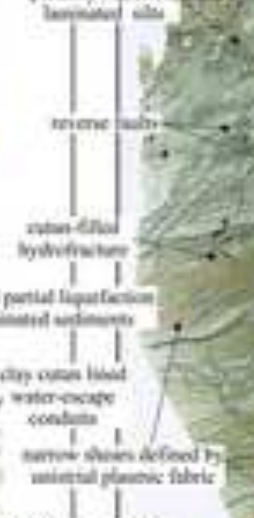

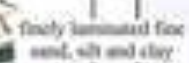

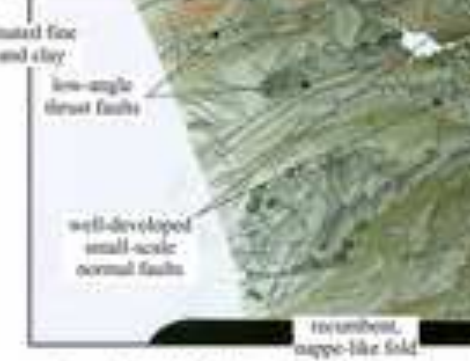

Sumple Sesses: Haims Hern

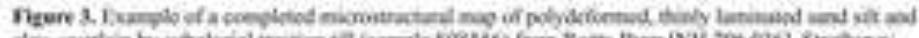

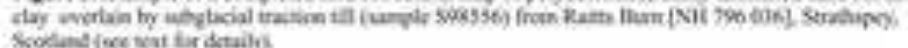




\section{Click here to download high resolution image}

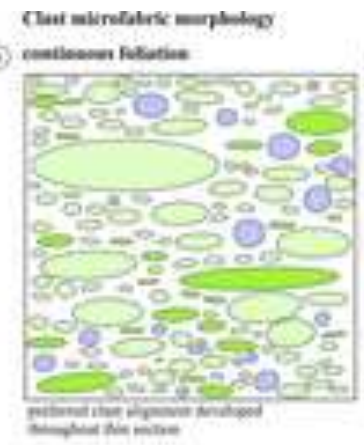

(b) vared Netatina

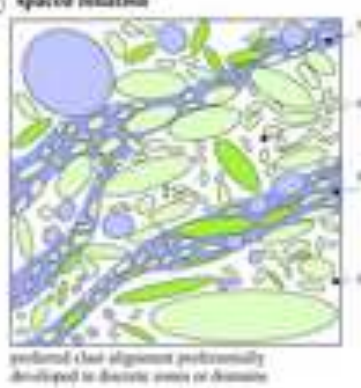

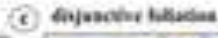

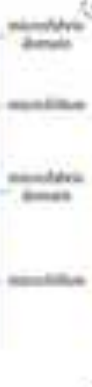

\section{a interine}

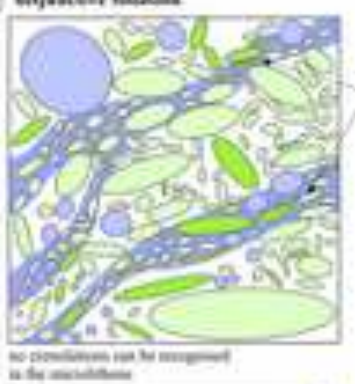

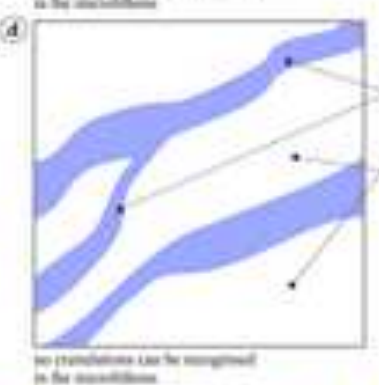

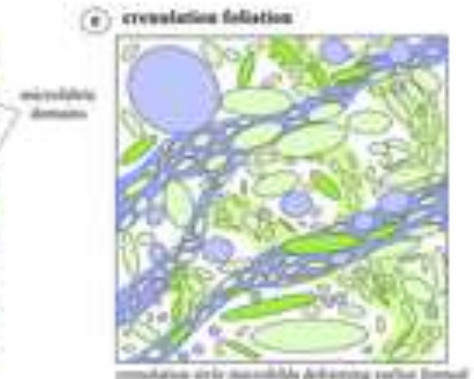

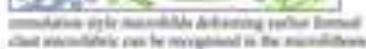

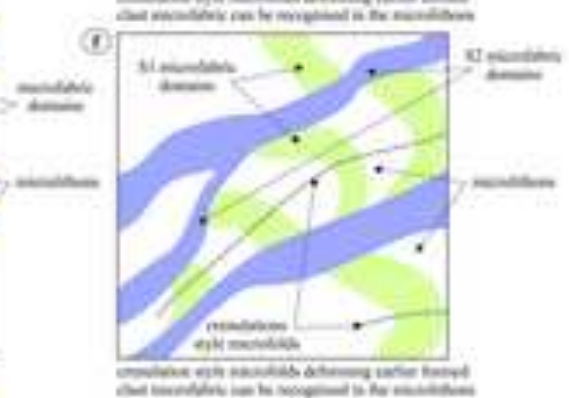

6. poulas

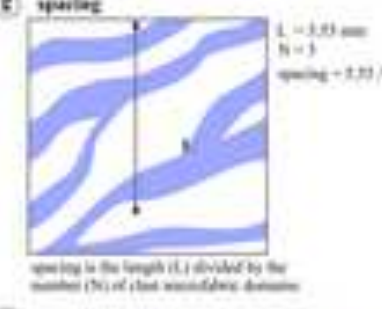

(1)

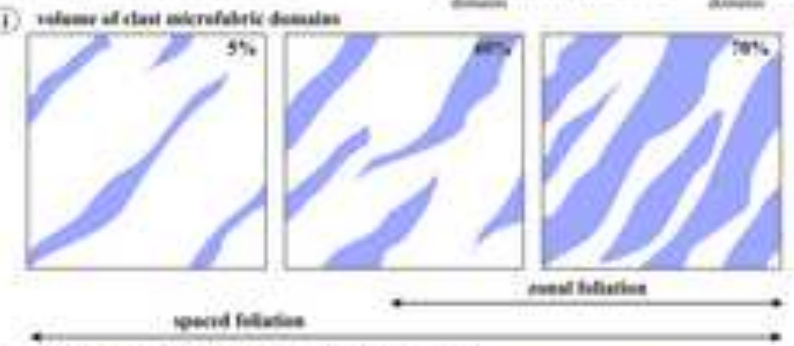

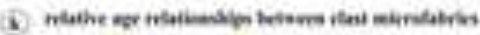

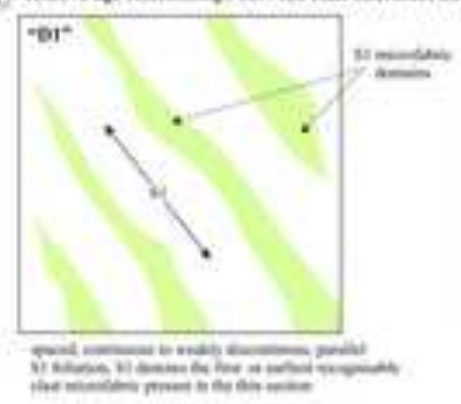

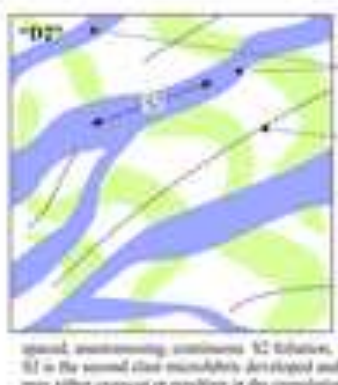

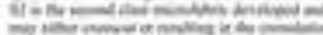

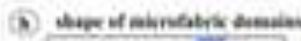
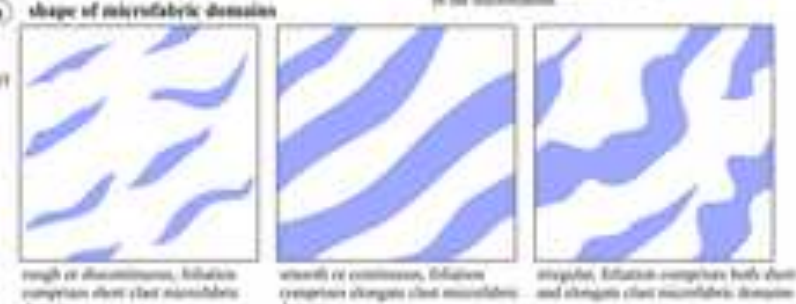

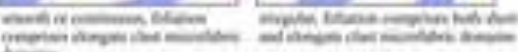

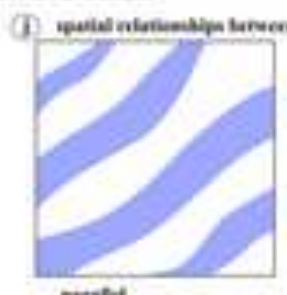

perstart

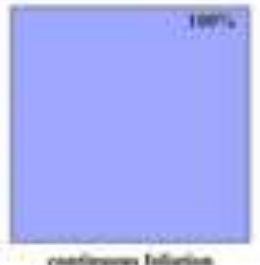

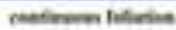

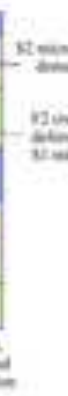

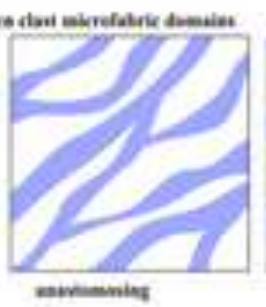

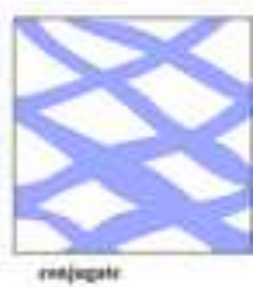

reakeate

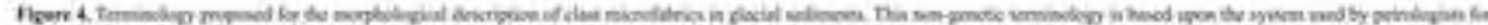

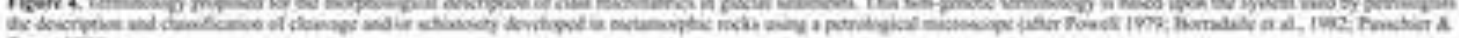
Tros inve

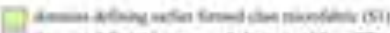

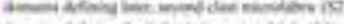

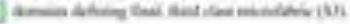

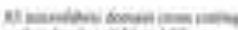

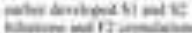


a

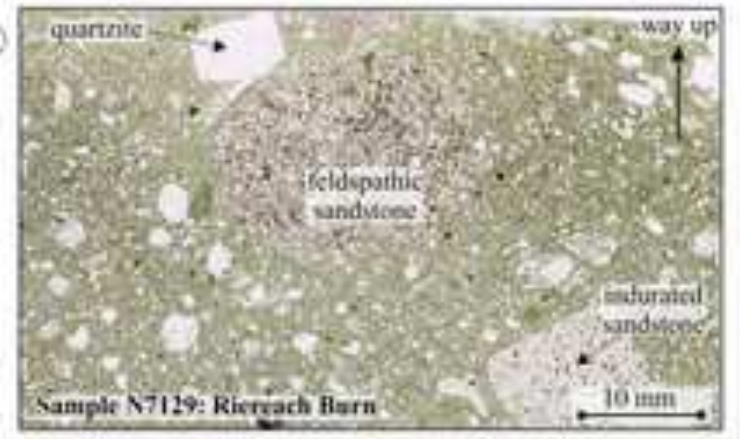

b

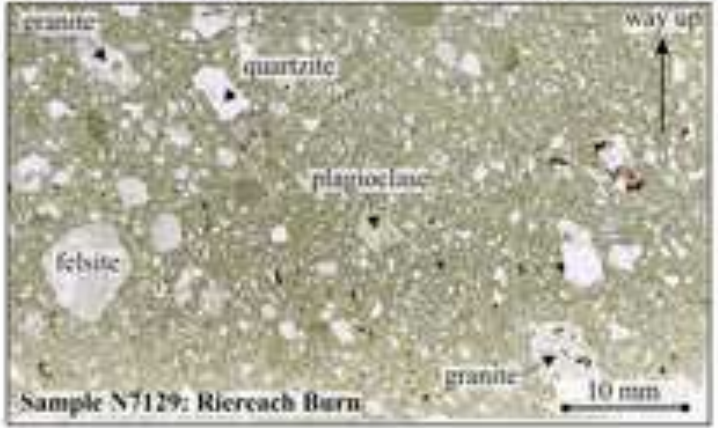

(c)

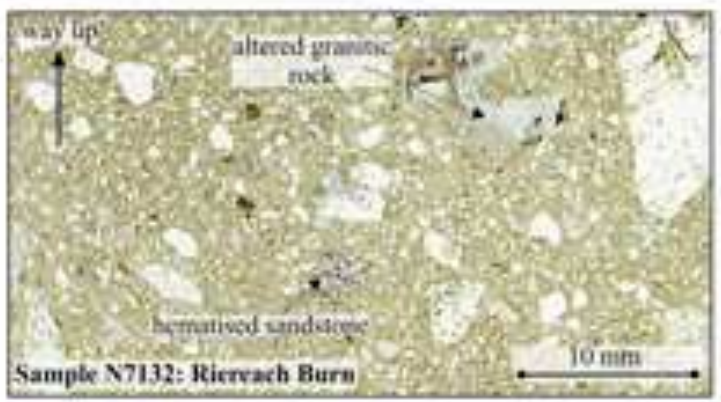

d

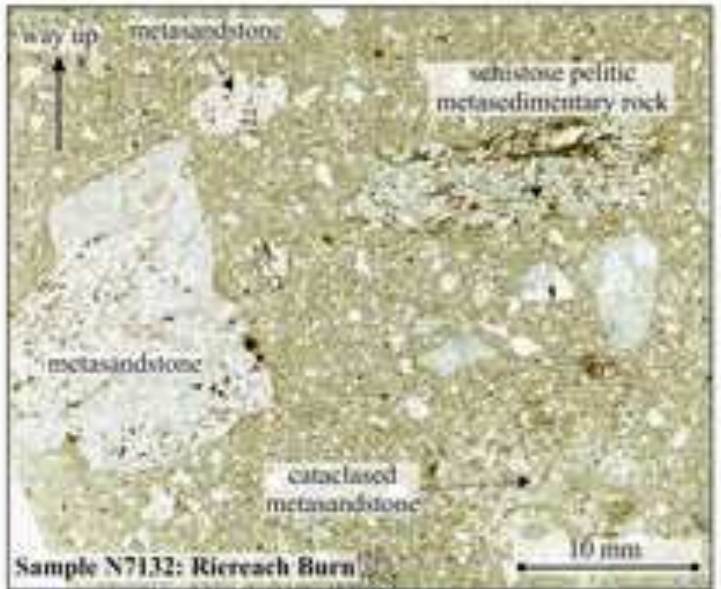

fatkic wropping around langat elau
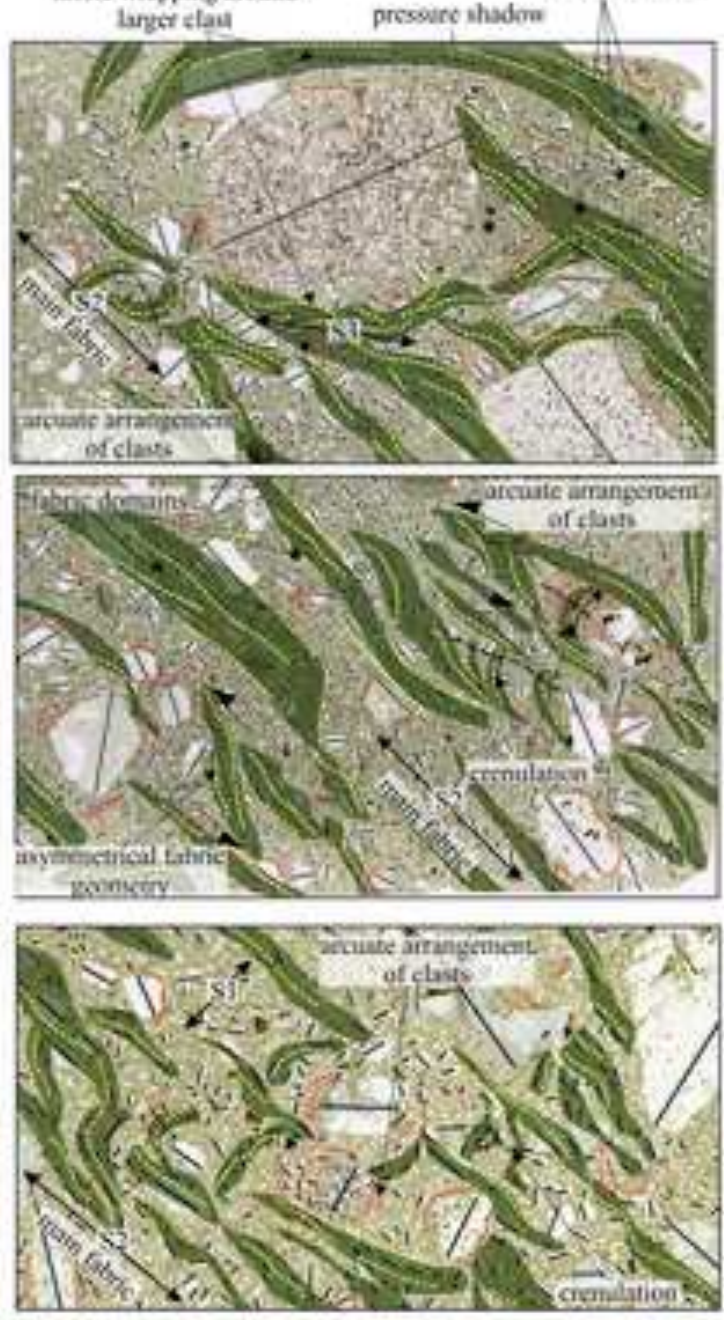

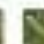

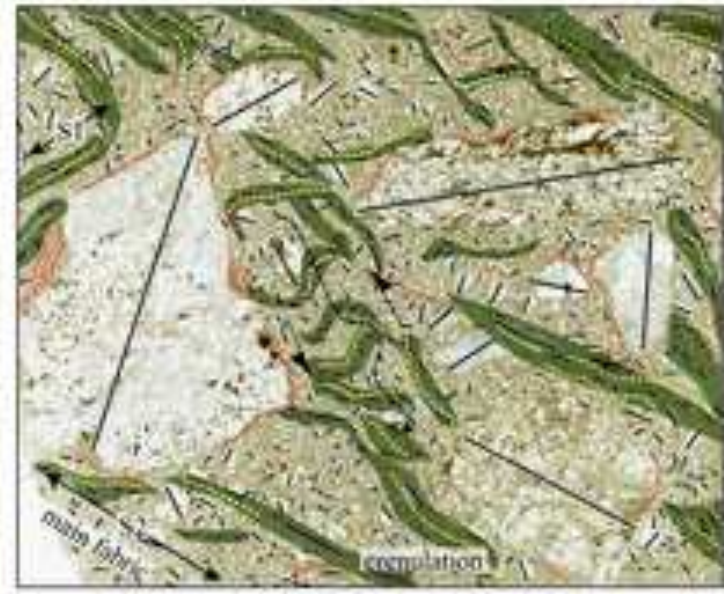

mócrochast fabric defind by clast heig axes

loegg axis of clasts

- sense of sharar

arvasie to lincar grain agsotgatcs

2xial surfaces of cremulations microfolds

$\stackrel{\longrightarrow}{\longrightarrow}$ to $=$

oricntation of Etaric(s)

Figure 5. Examples of detailed clast microfabrics relationships developed in a sandy subglacial traction till from Ricreach Bum, Scotland: (a) A spaced, discontinuous clast microfabric (S2) wrapping around a large, well-rounded clast of fine-grained sandstone with distinct 'pressure shadows' developed adjacent to this clast: (b) A spaced, discontinuous $\mathrm{S} 2$ microfabric with earlier formed areuate grain alignments and erenulated St microfabric preserved within tbe intervening mictolithons; (c) A closely spaced,

discontinuous elast microfabric with areuate grain alignments (turbate structures of van der Meer 1983) developed adjacent to, of enclosing granule to pebblo sixed clasts being preferentially preserved within the intervening microlithons; and (d) Crenulation-style microfolds deforming a closely spuced clast microfabric developed adjacent to a large, pebble sized elast of metasanistonc. These microfolds may have developed in response to either (i) the fecusing of shear adjacent to this rigid, relatively immobile clast, or (ii) localisation of deformation within the marix immediately adjacent to the clast associased with the rotation of this pebble. 

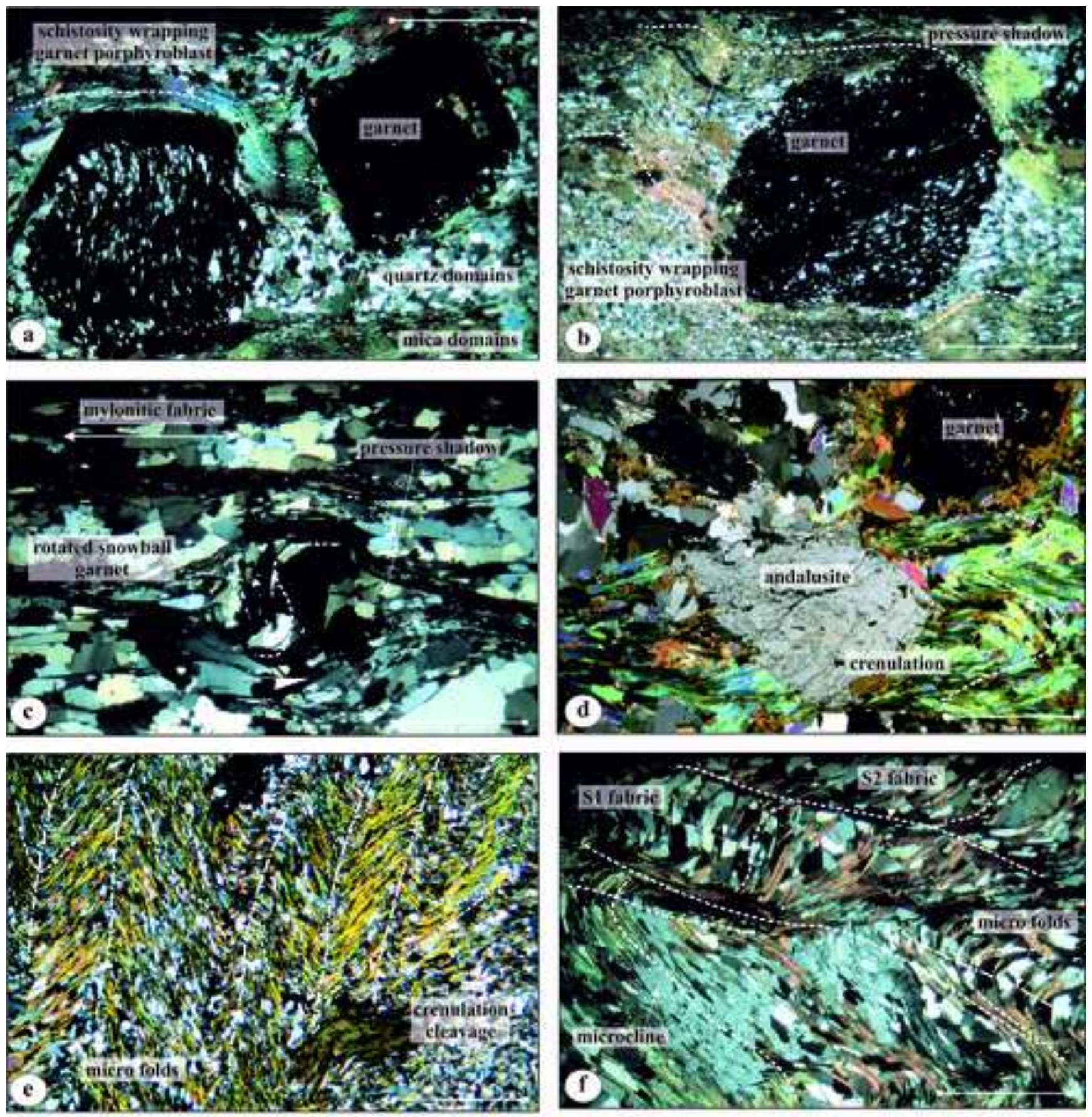

Figure 6. Photomicrographs showing examaples of foliations developed upper greenschist to amphibolite facies metamomhic rocks: (a) Poikiloblasts of garnet (black) wrapped by a well-developed schistesity within a amphibolite facies garnet-biotitemica schist (Neoproterozoic in age Leven Sehist, Glen Roy, Scotland; see Phillips and Key, 1992 ) defined by alternating quartz (white to grey) and mica (predominantly muscovite, blue to yellow-green colour) domains; (b) Poikiloblast of gamet wrapped by a well-developed schistosity (defined by muscovite (pink to yellow-green) within a amphibolite facies gametbiotite-mica schist (Neoproterogoic in age Leven Schist, Glen Roy, Scotland), note the presence of Ienticular pressure shadows composed of quartz immediately adjacent to the gamet; (c) Rotated, 'stowball gamet porphyroblast developed within a partially annealed, micaceous quartz mylonite (Eilrig Shear Zone, near Fort Augusius, Scotland; see Phillips et al., 1993): (d) Anhedral andalusite (pale grey) porphytoblast overgrowing a S2 crenulation cleavage within a contact metamorphosed gamet-biotite-mica-schist (Strath Ossian, Scotland). The andalusite developod as a festalt of thermal of coenact metamorphism associated with the emplacenent of the Strath Ossian grasite pluton; see Key et al.. 1993). Also note the development of a biotite (red-brown) reactsou rim on the relict garnet popphyroblast due to the break dows of this mineral during this contact metamorphic event; (e) Well-developed crenulation cleavage developed within a middle to upjer greenschist facies chlorite-muscovite-schist (Neoproteronoic Southem Highlands Group. Scotland). The earlier S! fabric defined by shape and optically aligned muscovite flakes (yellow) is deformed by a series of tight, angular microfolds which define the $\mathbf{S 2}$ fabric; and (f) Irregular, anhodral microcline porphiyroblasts (blue grey) overgrowing a well-developed crenslation sleavage/schistosity developed within a upper groenschist to lower amphibolite facies mierocline-muscovitebiotite-schist (Neoproteroxoic Southern Highlands Group, Scouland). All photographs taken under crossed polarised light, scalebar $1 \mathrm{~mm}$. 

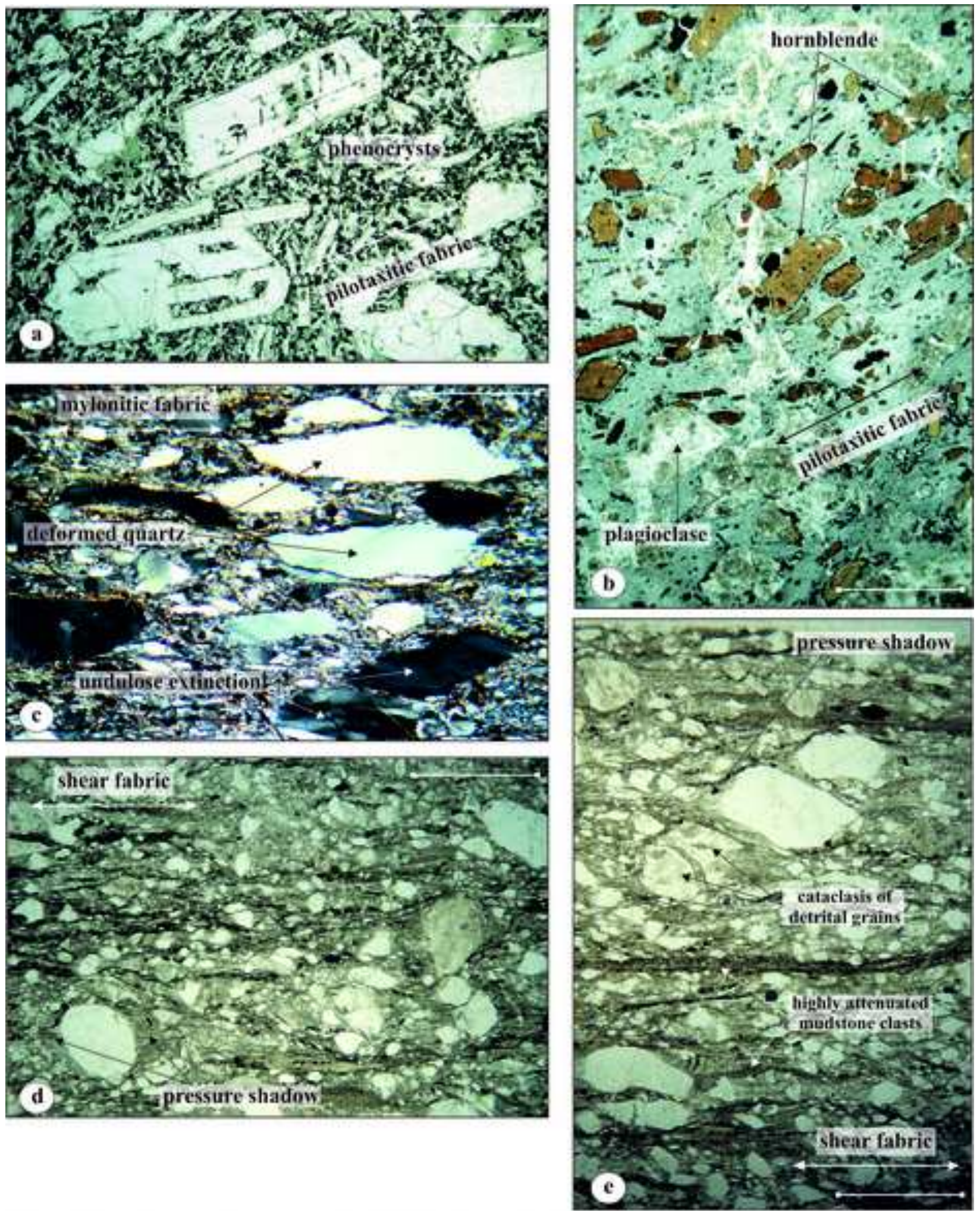

Figure 7. Photomicrographs showing examples of foliations developed within extrasive and intruaive igncous rocks, a mylonitised metasandstone and sheared sub-greenschist facies metamorphosed wacke sandstones: (a) A tigned, lath-shaped plagioclase (colourless) pbenocryses defining a moderate to well-developed pilotaxitic (flow) fabric developed within a basaltic lava (Casboaiferous in age, Clyde Plateau Lavas, Midland Valley, Scotlasd) (plane polarised light, scale bar = 1 mun): (b) Aligned, anhedral to subhedrai bomblende (brown) phenocrysts defining a well-developed pilotaxitic fabric deweloped within an andesitic high-level intrusion (The Imperial Porphyry', locality unknown, Egypt) (plane polarised light, scale bar - 1 men); (c) Elongate, single quartz crystals aligned parallel to a well-developed mylonitic fahrie present within a mylonitised metasandstone (Neoproterozoic, Southem Highland Group, SW of Stonehaven, Scotland; Phillips and Auton, 1997) (crossed polarised light, scale bar = $1 \mathrm{~mm}$ ): (d) and (e) Well-developed shear fabric developed within a highly deformed sub-greenschist facies wacke metasandstone from the Moniaive Shear Zone, \$W Scotland (Phillips et aL, 1995). Deformation has resulted in the variable jotation of detrital grains, the development of asymmetrical pecssure shadosis adjacent to these detrital grains, localised cataclasis (fracturing) of rigid quartr and feldspar grains und attenuation of softer muilstone intraclasts (plabe polarised light, scale bar = I mm). 

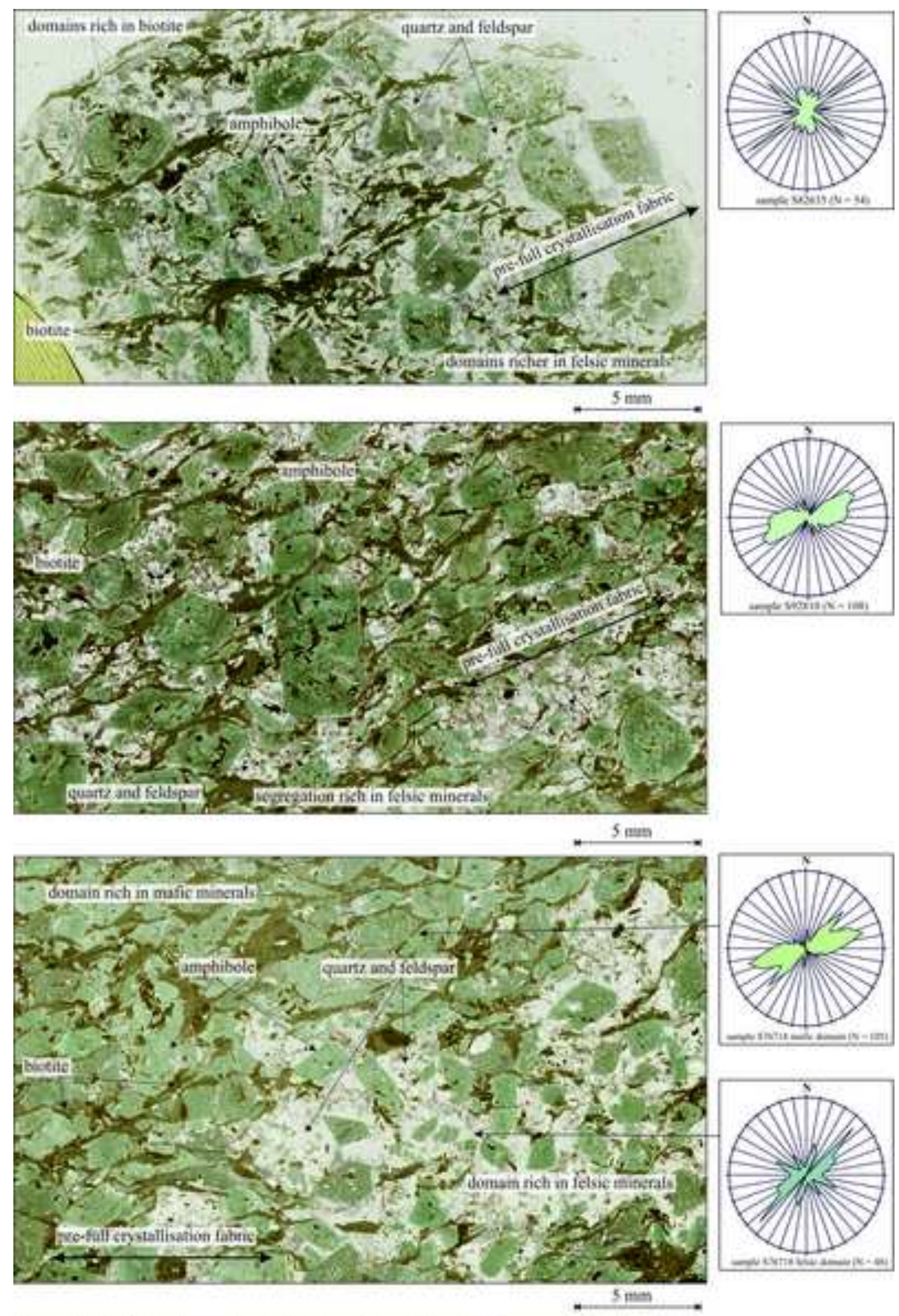

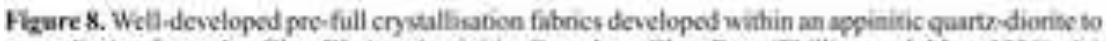

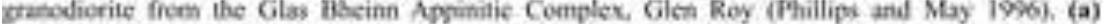
Moderately developes domainal fatric defined by paralliel to wealdy anasoemoninge diventinuon

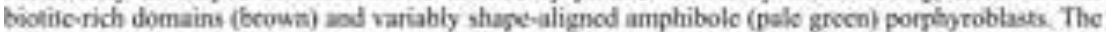
imervening enicrolithons or fiddyodtuc domains are richer in colourless quart and feldspar imainly plagioclaick (b) Well-developet, elosely spaced, amastomosing pre-full crystallivation fotation defined

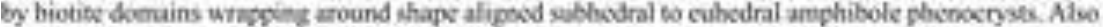
boef lecally developed pressure shabows developtl adjacent to the amphibole phenocrysts eomfored of unotrained quarte and feldspar; and (e) Clesely spaced to locally coationous pre-full crystallisation fatric defined by shape-alignsd biokile and amphibolk. Note the more random oricutation of the amphibole phesocrysts withis the donain rich in felsic minerals (see teat for details). Insets: rose diagrams showing the orientation of the main fabric(s) defined by the preforred alignment of the

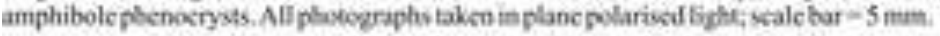


progressive development of the prefull erystallisation fabric

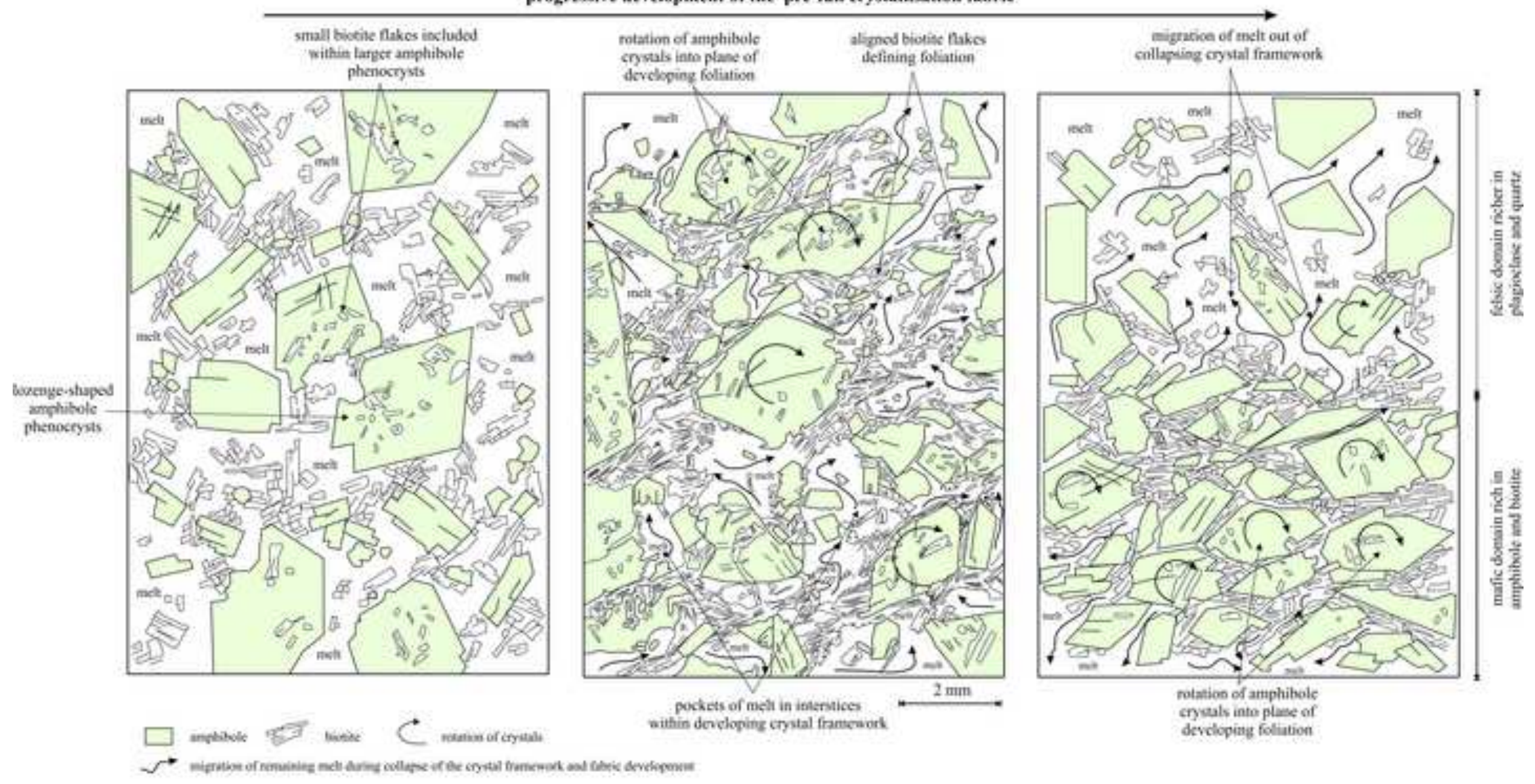

Pigure 9. Diagram shwwing the progressive development of the preffuli crystallisation fabric within the appinitic quarte-diorike to granodicrite caken faom Phillips and May (1996). (a) randembly orientalds biotite and amphibole crysuls forming as open crystals frame wotk within the slowly crystallesing paritic melt: (b) On ser of

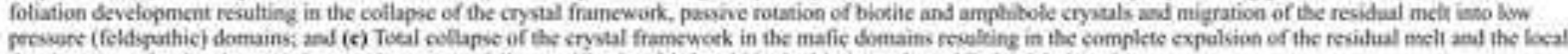

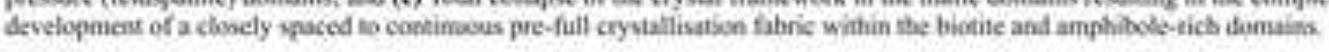




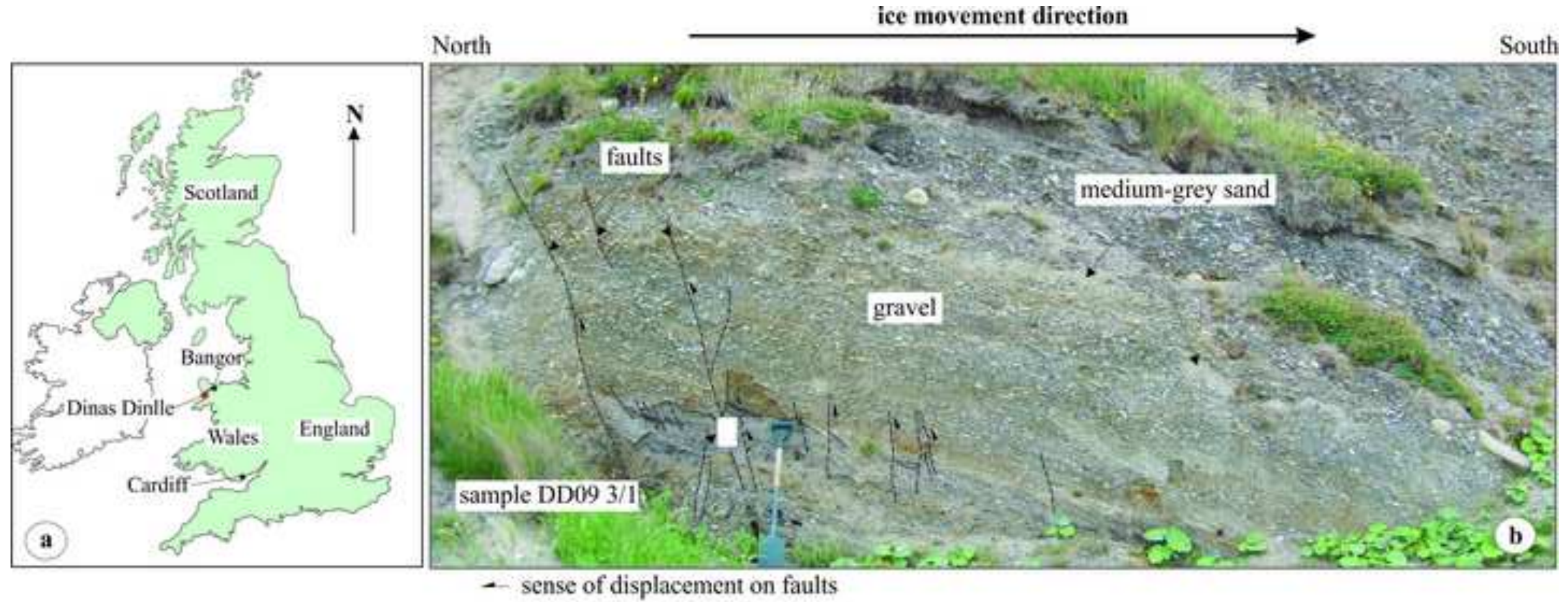

Figure 10. (a) Map showing the location of Dinas Dinlle, North Wales. (b) Photograph showing a steeply inclined to subvertical faults (downthrow to the north) offsetting bedding within the sands and gravels exposed at the southern end of the larger northern section at Dinas Dinlle. Also shown is the location of sample DD09 3/1. 

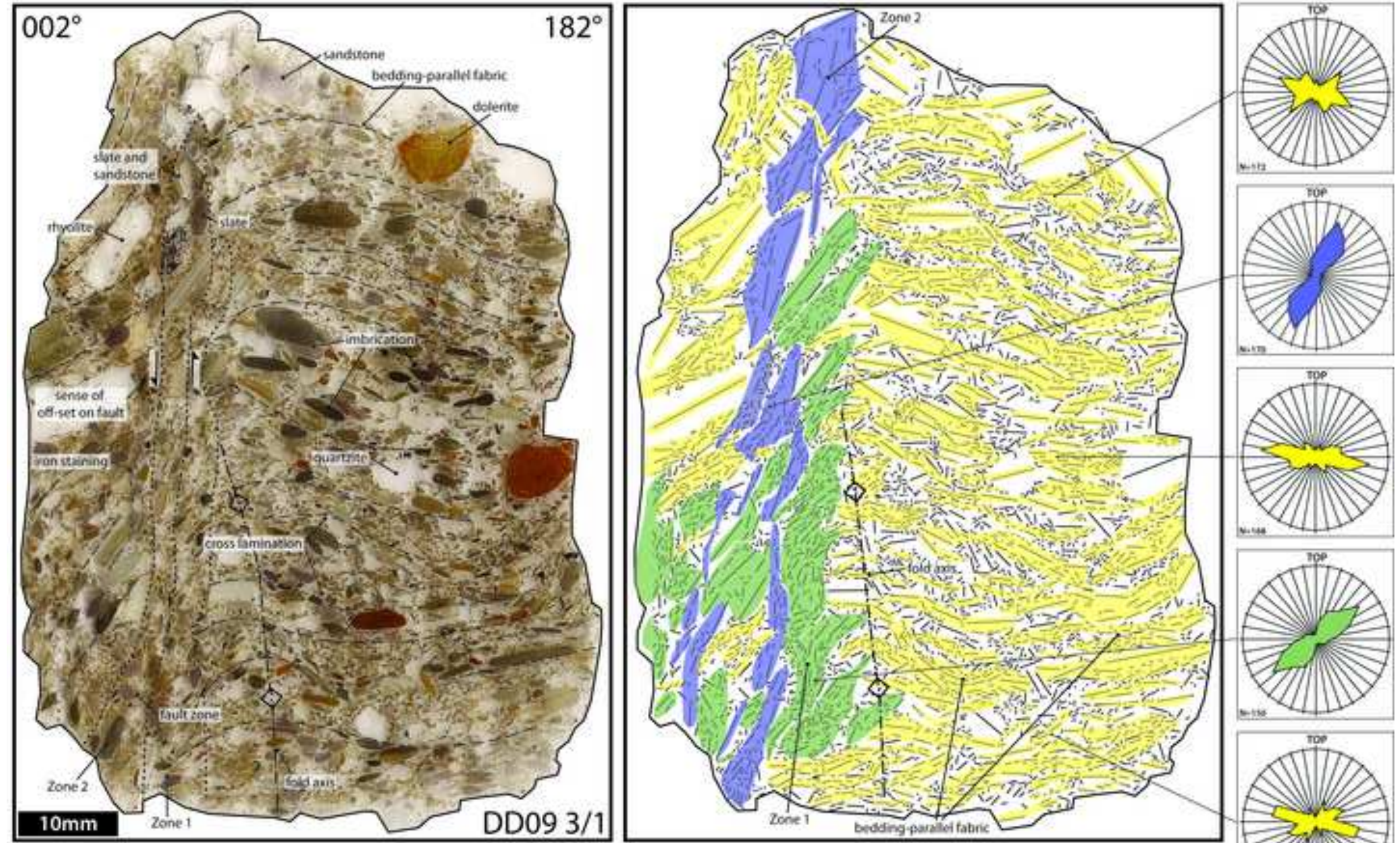

- long axis of clants - - parrallel bedíng defined by clast long zei

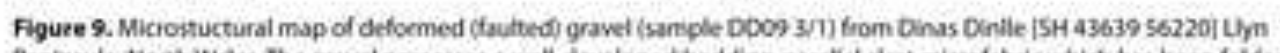

...- outline of fault zones $\rightarrow$ sense of shear .., wail trace of fold

Peninula, North Wales The grawel possesses a well-developed bedding-parallet clast microdabric which has been folded by an open, upright structure. This fold has been cut by a relathely later steeply inclined fault zone isee text for detalst.

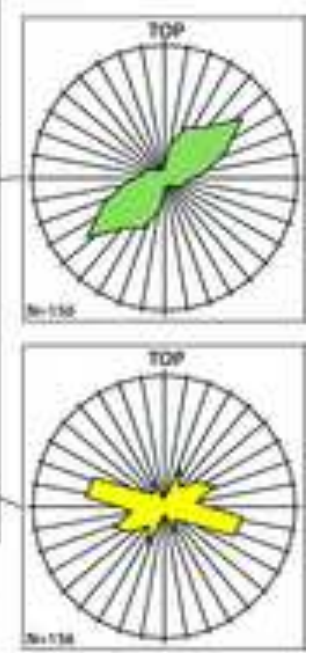


North

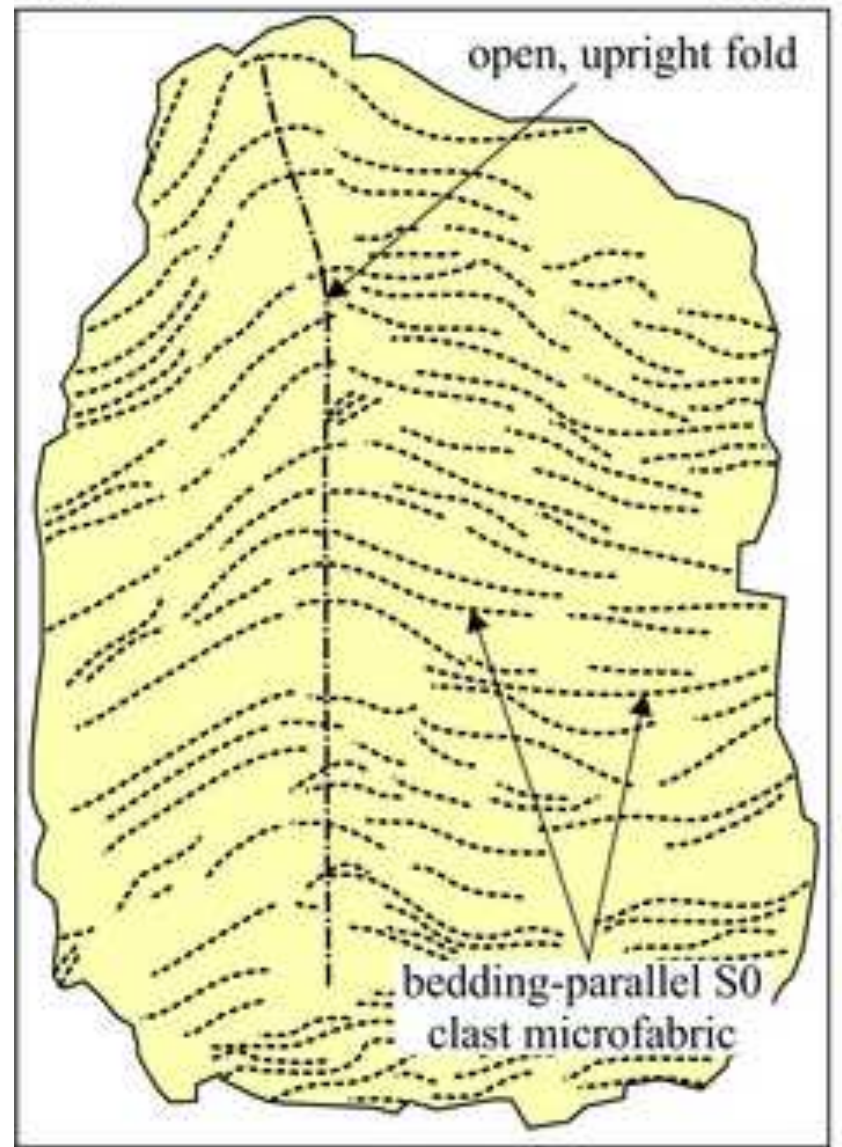

Stage 1: initial folding
South North

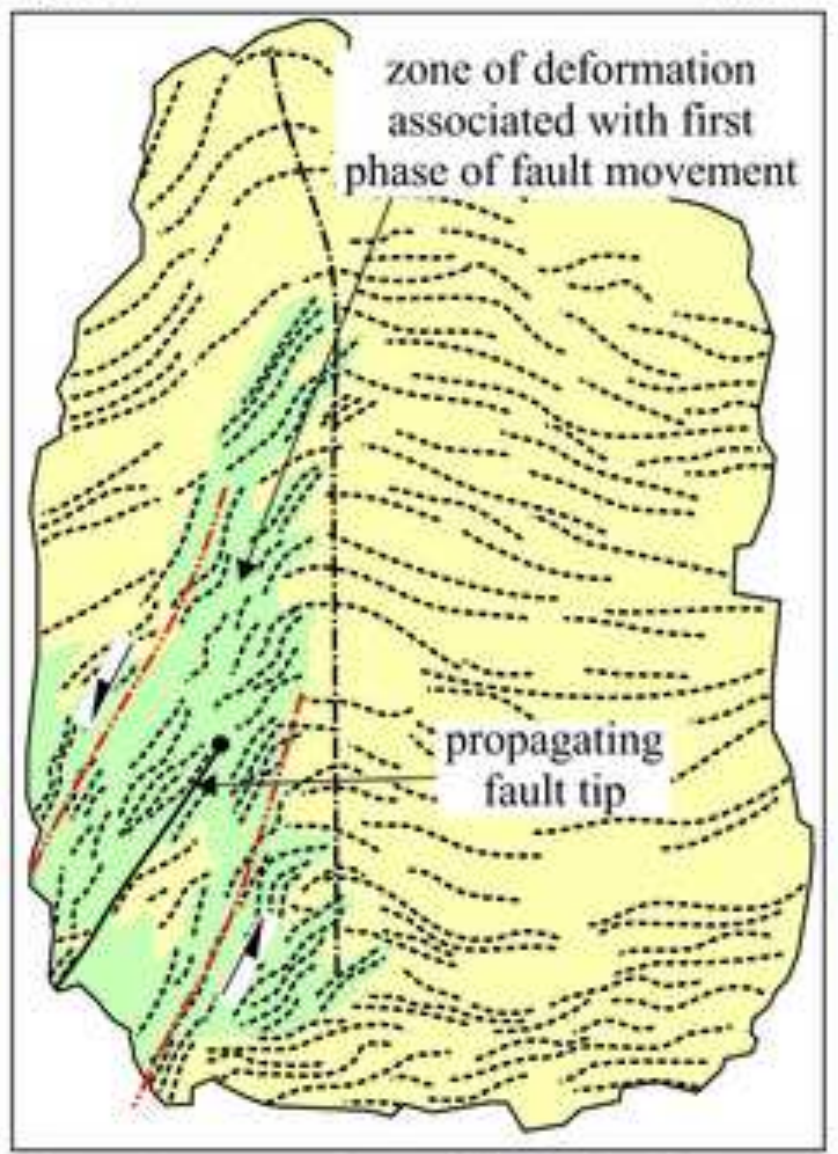

Stage 2: propagation of fault tip during the first phase of fault movement
South North

South

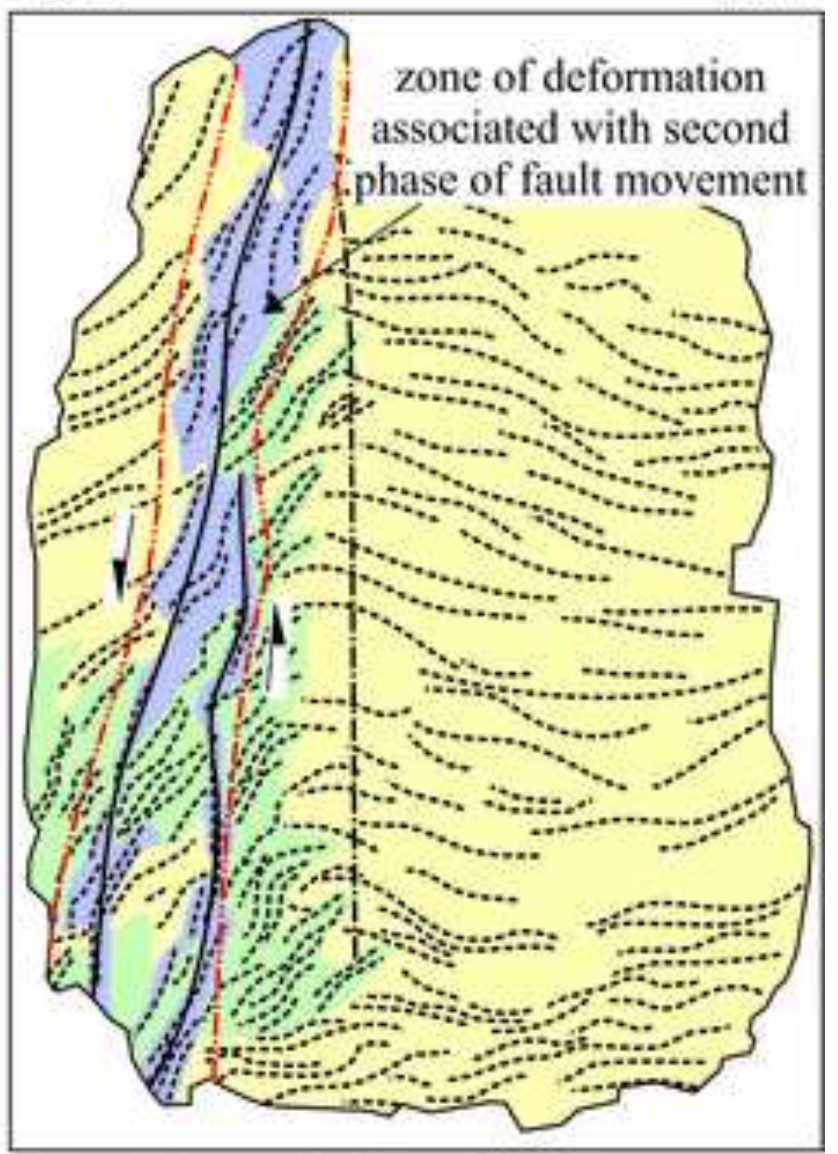

Stage 3: second phase of fault movement accompanied by reorientation of applied stress regime during faulting

$\Longrightarrow$ sense of movement on fault, fold axis $/$ fault

Figure 12. Model for the progressive development of the normal fault present within gravel sample from Dinas Dinlle based upon the interpretation of the microstructural map completed for this thin section. 


\section{Click here to download high resolution image}

(a)

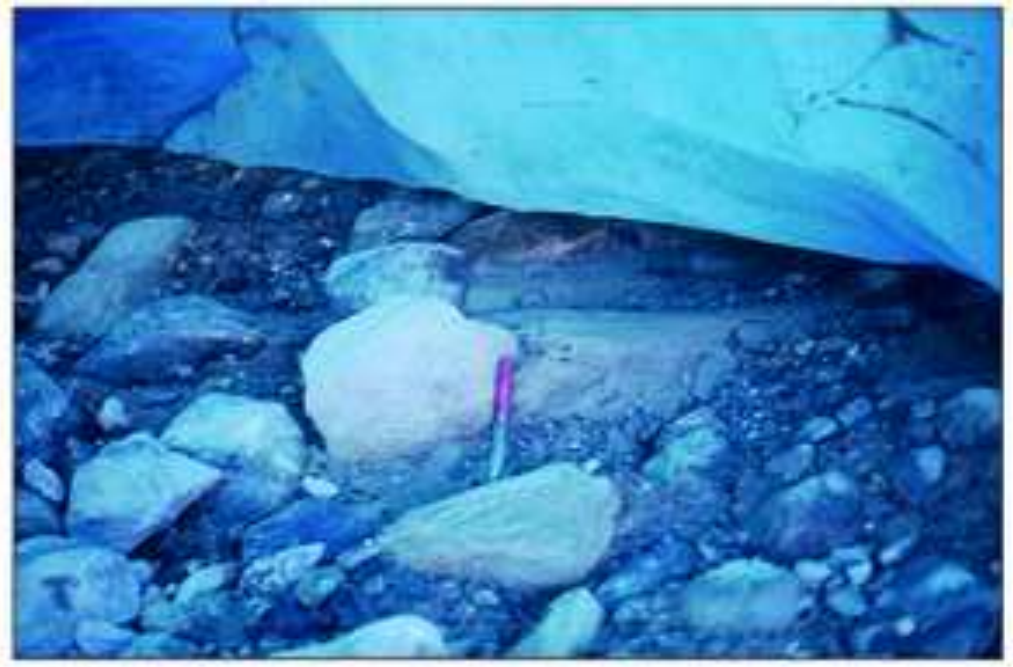

(b)
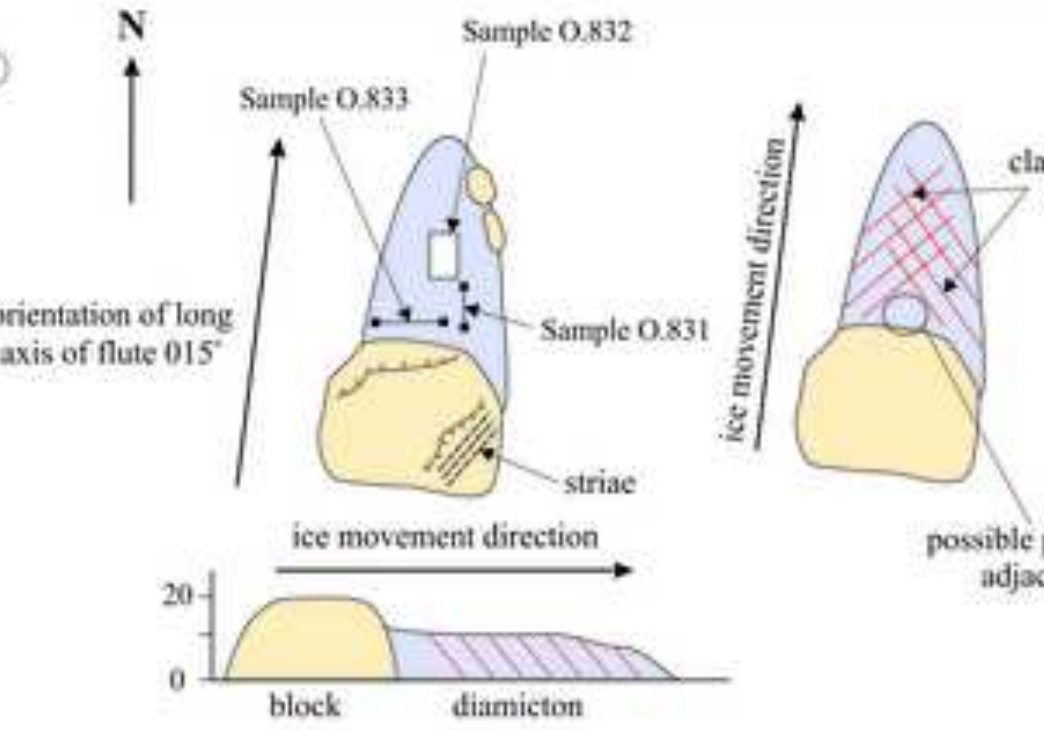

clast microfabrics

apparent dip of weaker

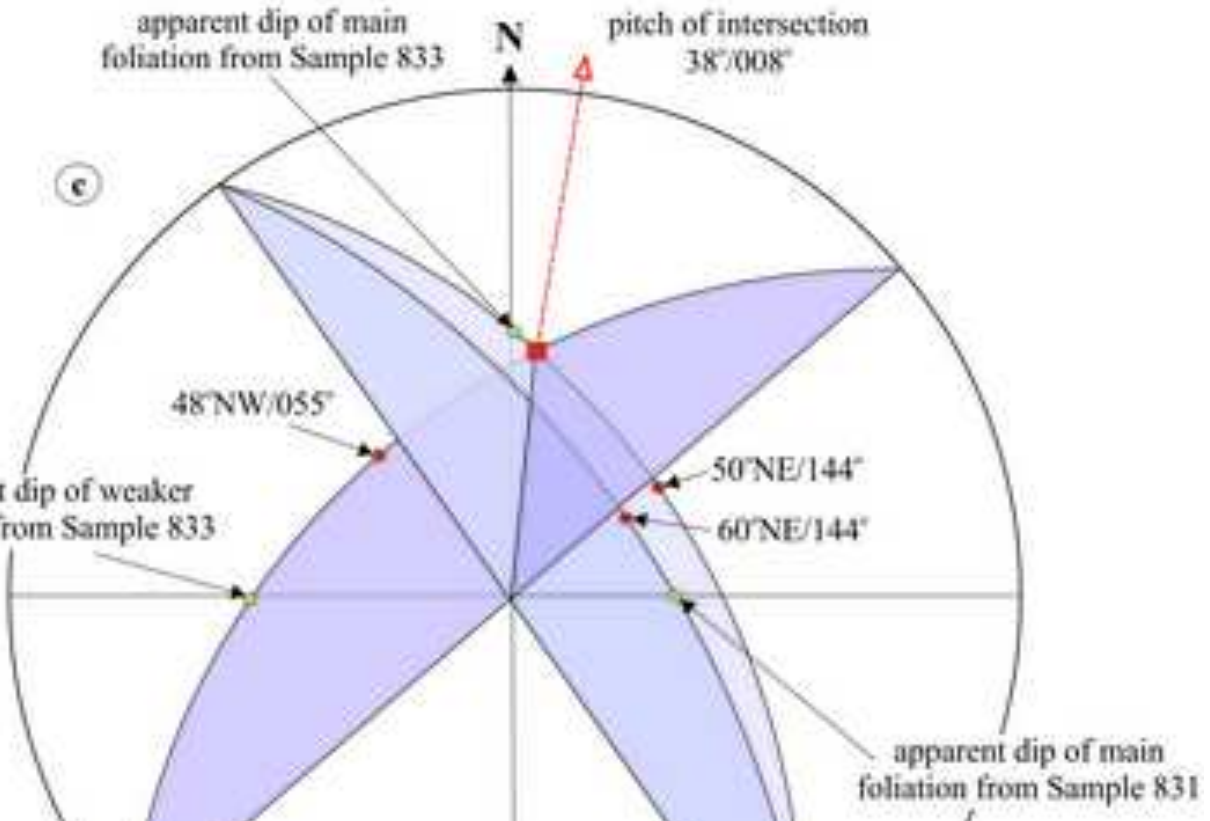

possible pressure shadow strike of weaker foliation
from Sample 832 adjacent to block

Figure 13. (a) Photograph of a small flute formed in the lee of a large boulder exposed in a portal during the 1986 annual retreat of the Turtmann Glacier, Switzerland; (b) Field sketch showing the location of the three samples of till taken from the flute; (c) Lower bemisphere stereographic projection showing the orientation of the dominant elast microfabrics identified in thin section. Also shown on the figure are the relationships of these microfabrics to the ice. movement direction and orientation of the flute. 
Click here to download high resolution image

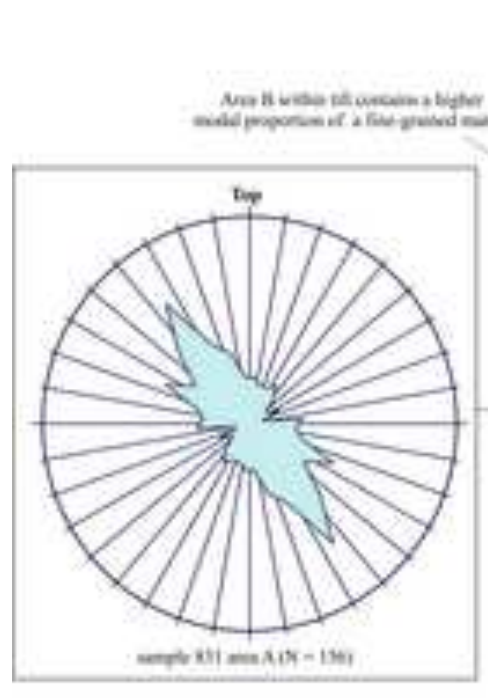

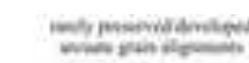

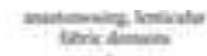
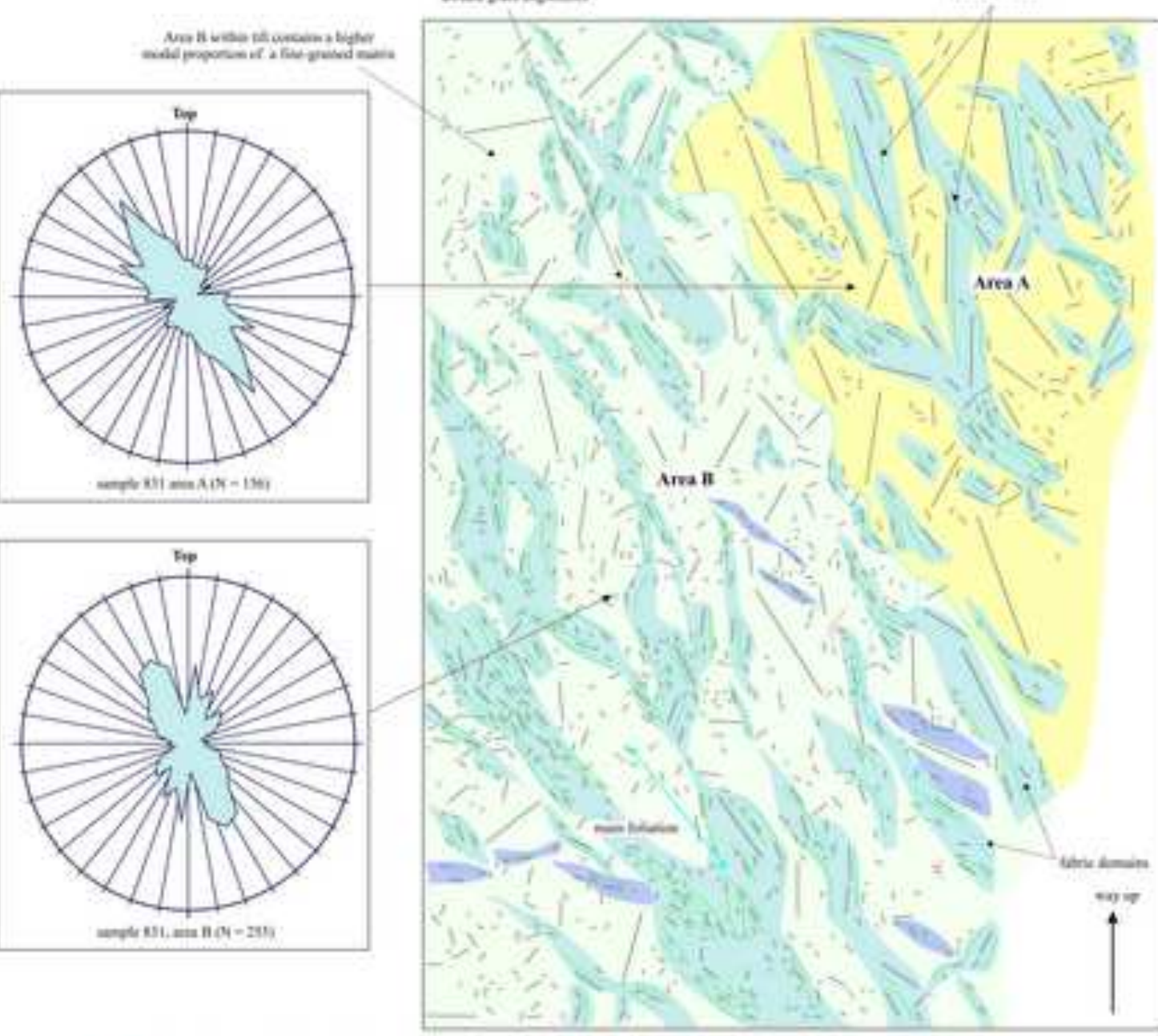

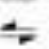

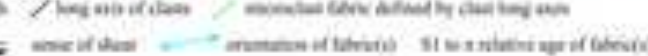

$10=$

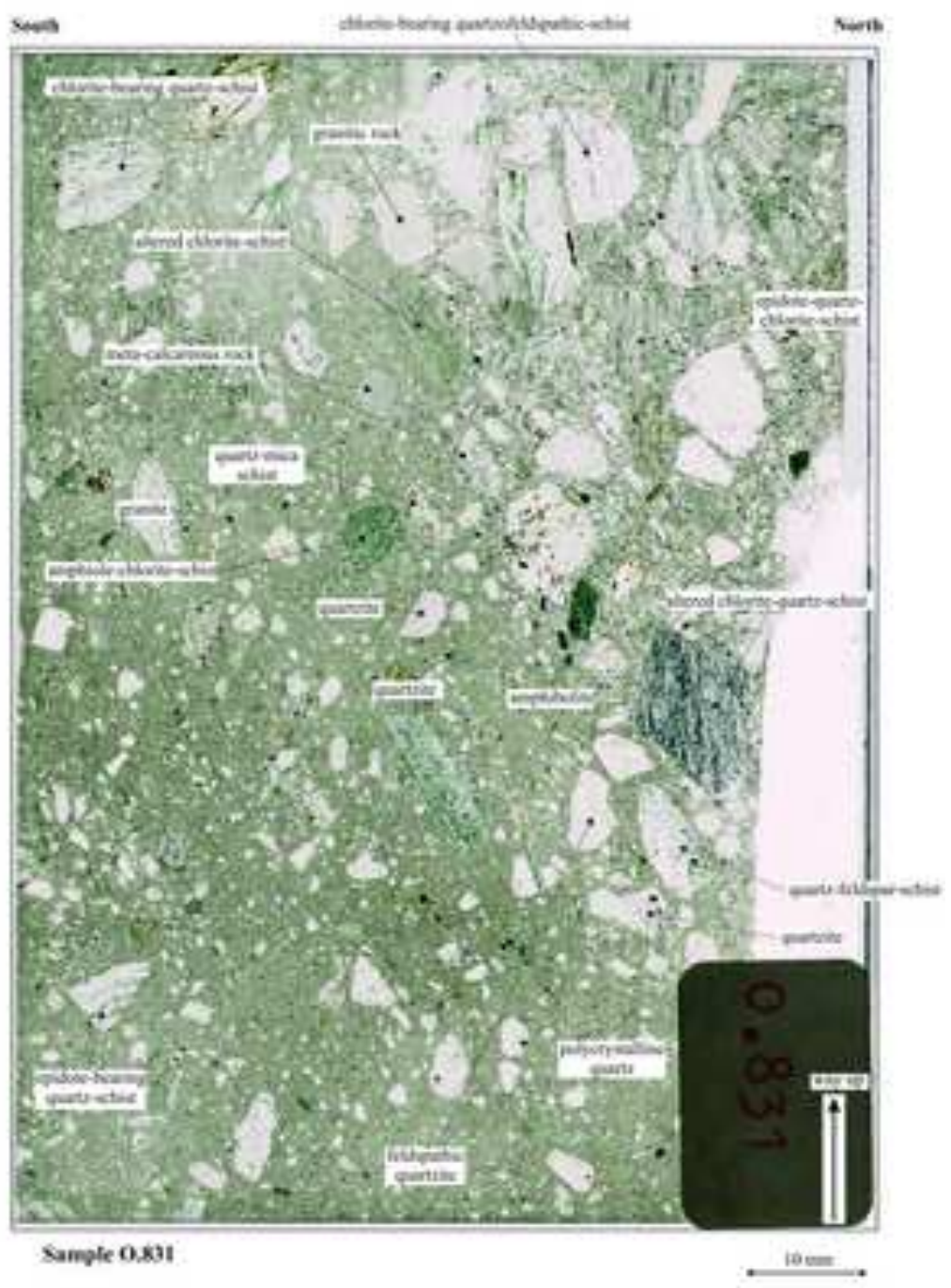

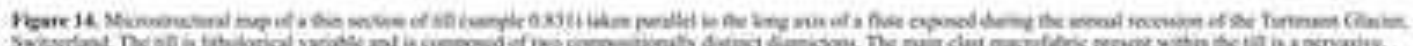

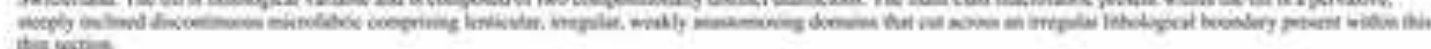


Click here to download high resolution image

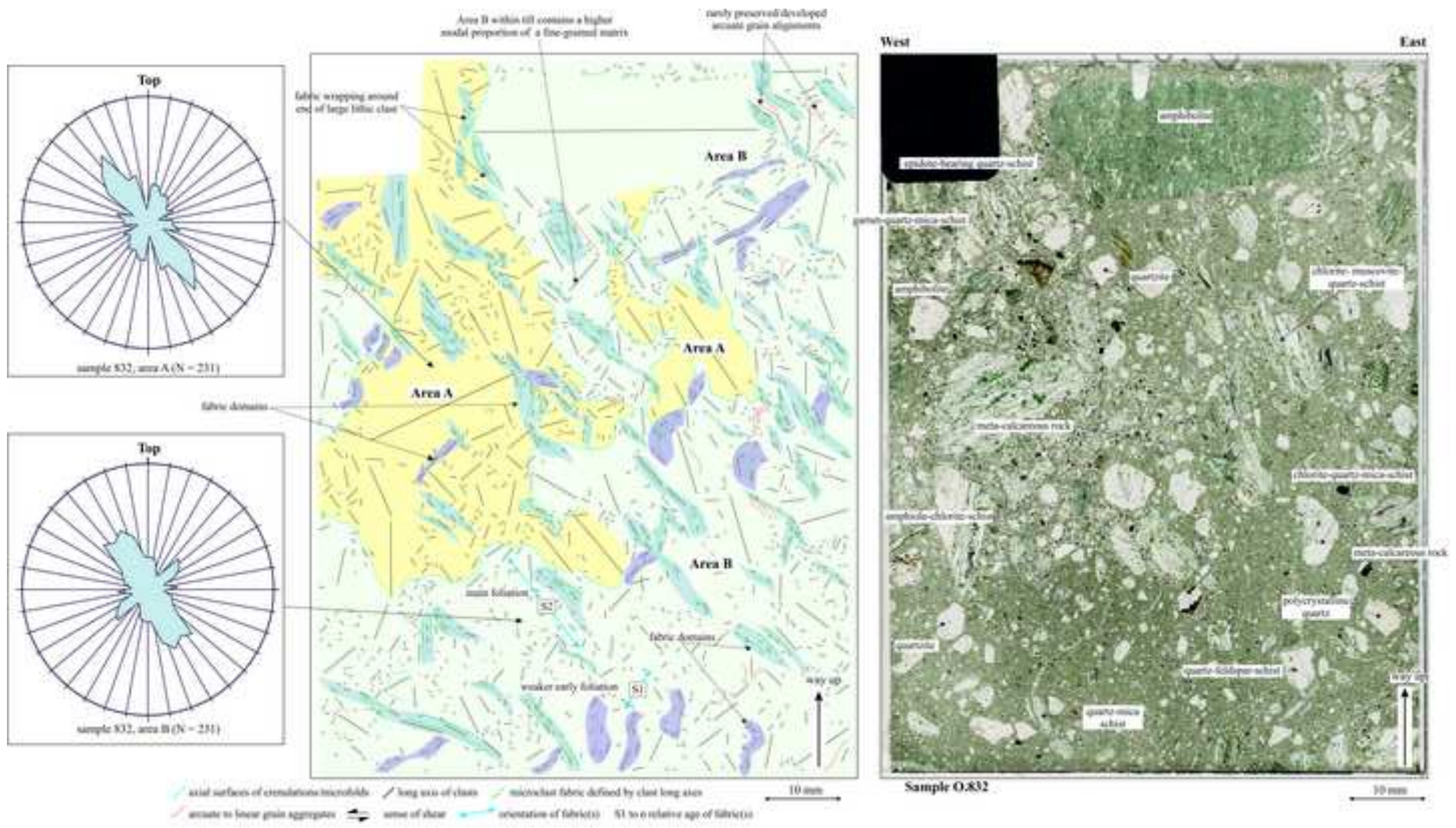

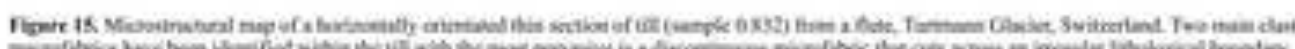

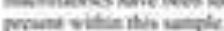




\section{Figure}

\section{Click here to download high resolution image}

West
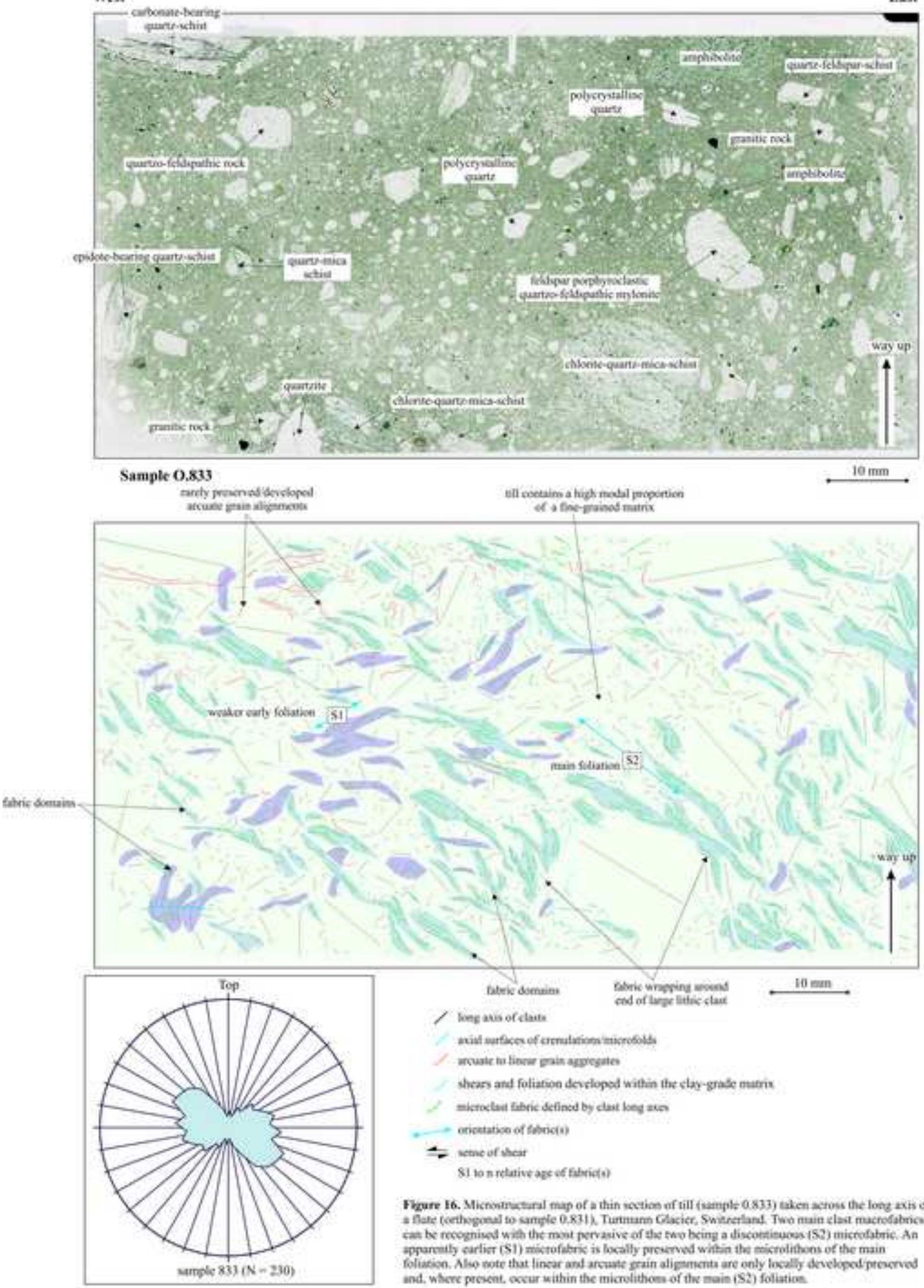

eti wodim a tuph mabal popertion of a the-grainos natin

$10 \mathrm{~mm}$
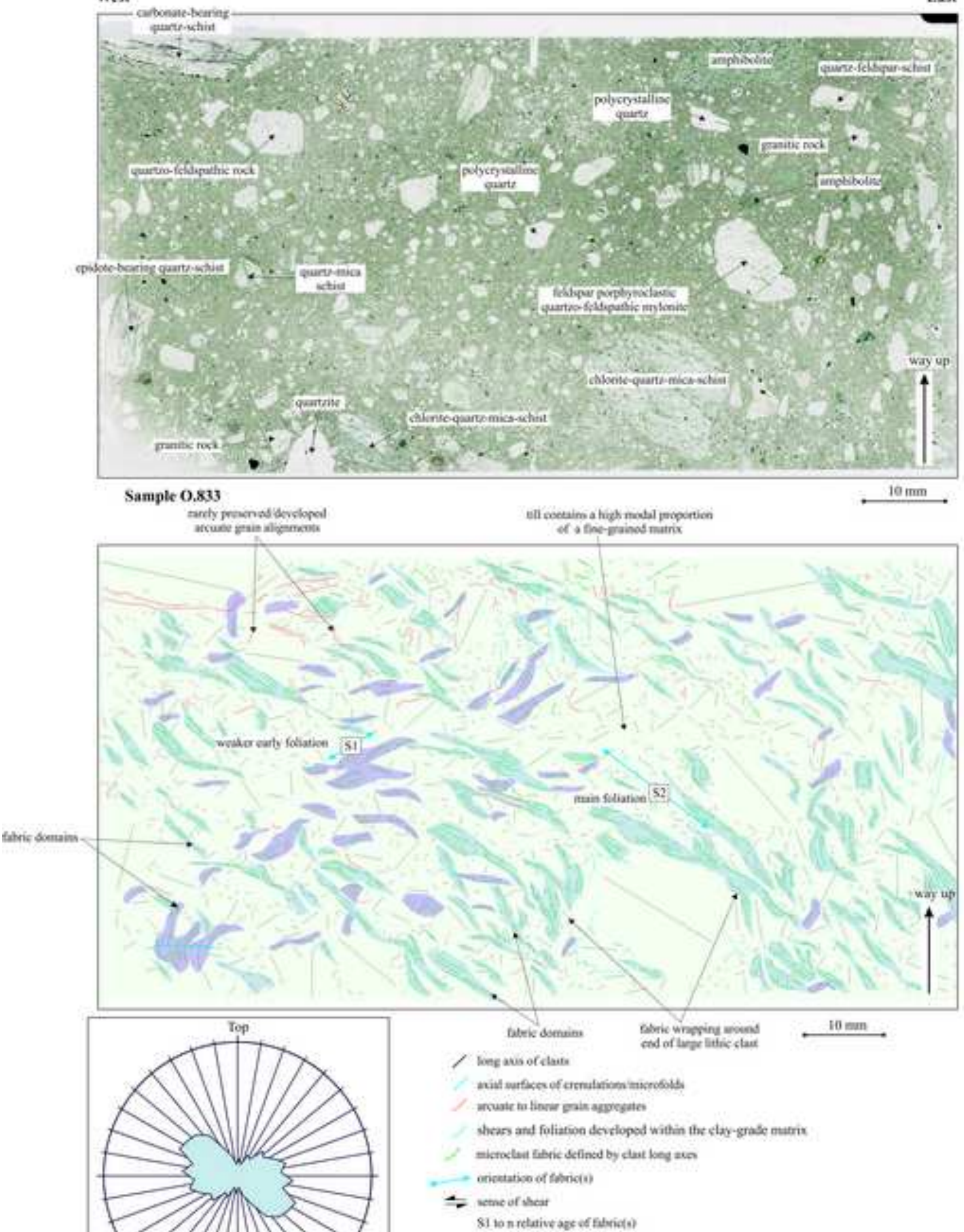

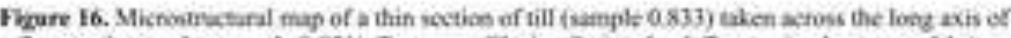

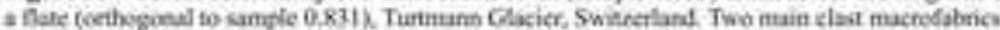

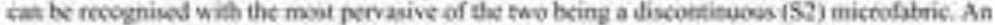
appurnily carlier (S1) mistofilenic is locally preserved within the exictolithons of the main

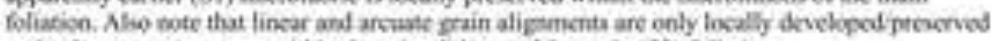
and. where pecsent. oxcur within the micrelithon of the main (S2) fotiatios 
Click here to download high resolution image
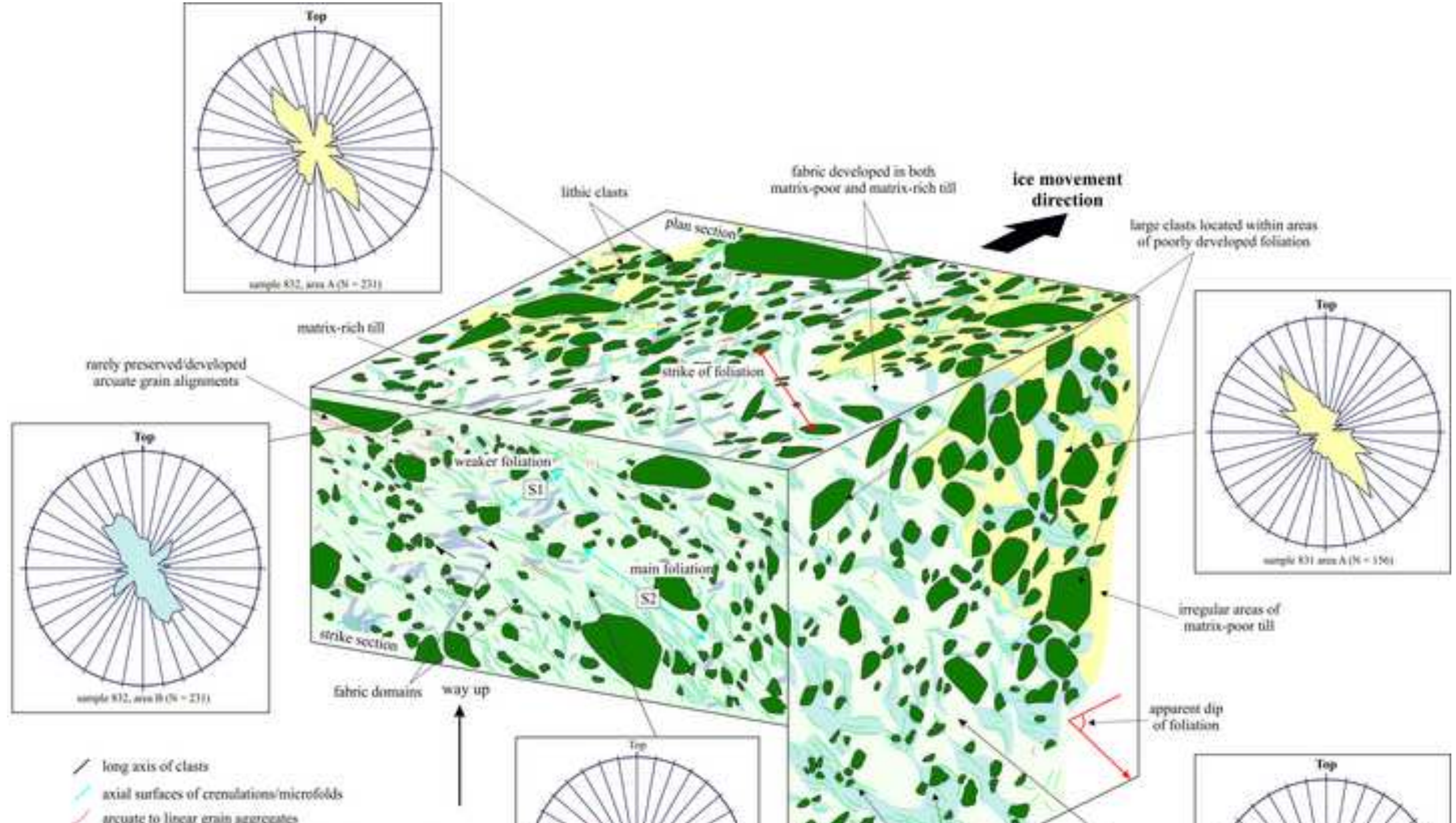

axial ruffaces of crendations microbods

ancuate to linear gnin aqgerpates

shears and foliztion developed within the clay.grade matrix

aicreclas fabric defined by clat long axes

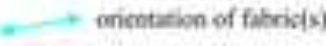

$\div$ senve of shat

S1 to a relative age of fibricis)

Fizure 17, Schematic 3D block diagram showing the relationships hetween the various microfabrics developed within the flufe. Noce that the boundary between the rwo litbologically distioct areas of diamietwo is highty irregular and that the muia chast microfletrics cut actoss dhis boendary.
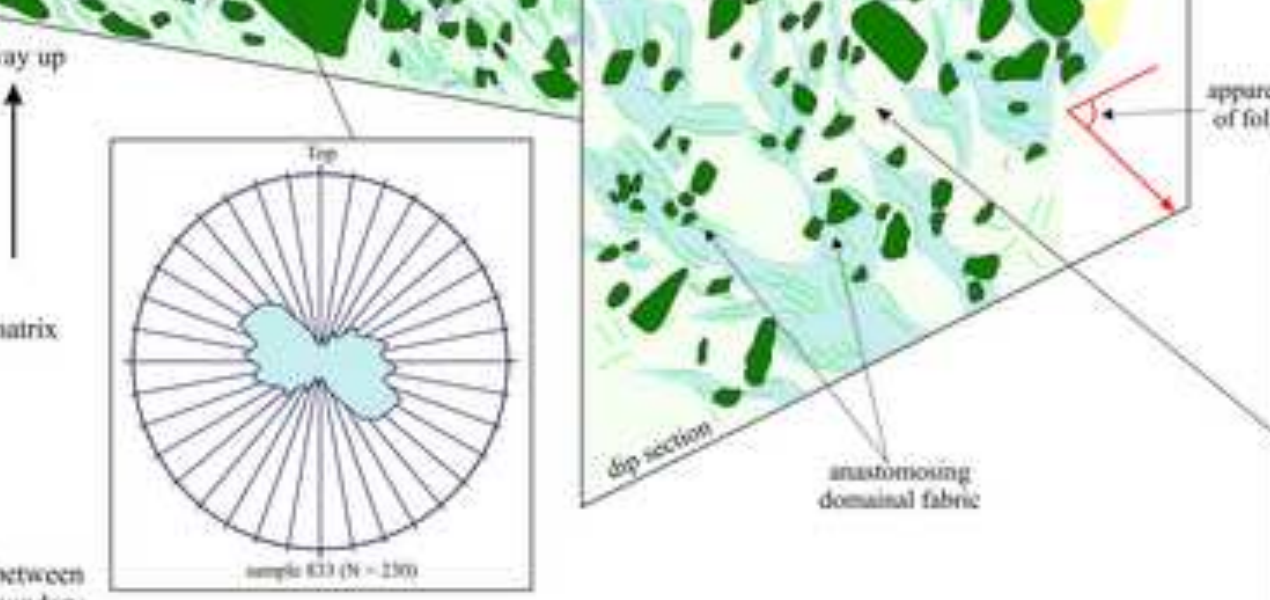

inepular areas of

matrie poot till
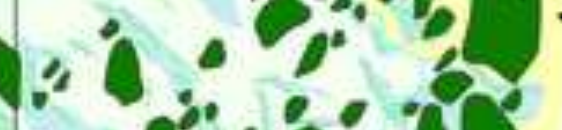

\section{upparest dip} of foliation

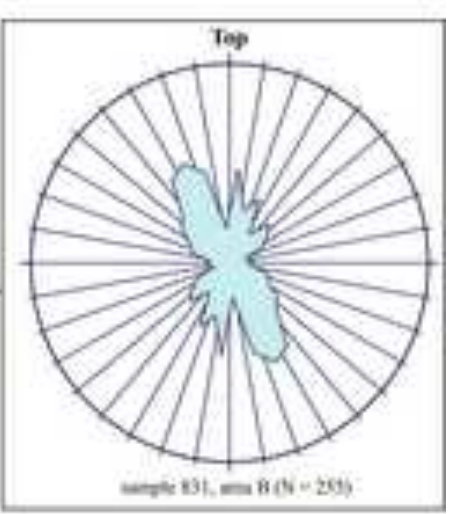




\section{Figure}

Click here to download high resolution image
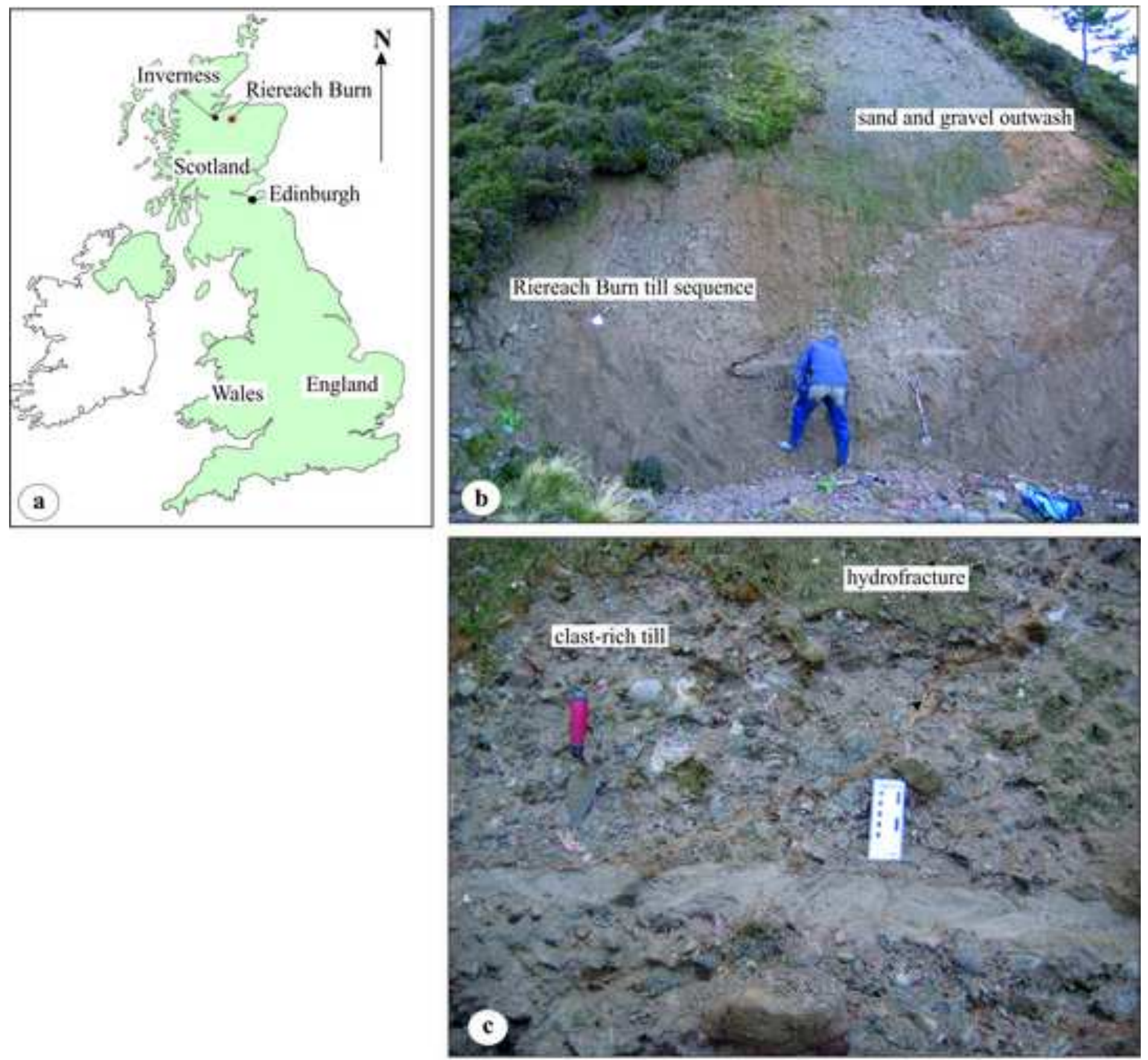

Figure 18. (a) Map showing the location of the Riereach Burn area, NE Scotland; (b) Photograph showing the glacial sequence exposed in Riereach Burn. The sequence comprises sandy and silty tills interstratified with sands, overlain by outwash sand and gravel. (c) Clast-rich, gravelly looking subglacial traction till exposed in Riereach Burn cut by a thin sand-filled hydrofracture. 
Click here to download high resolution image

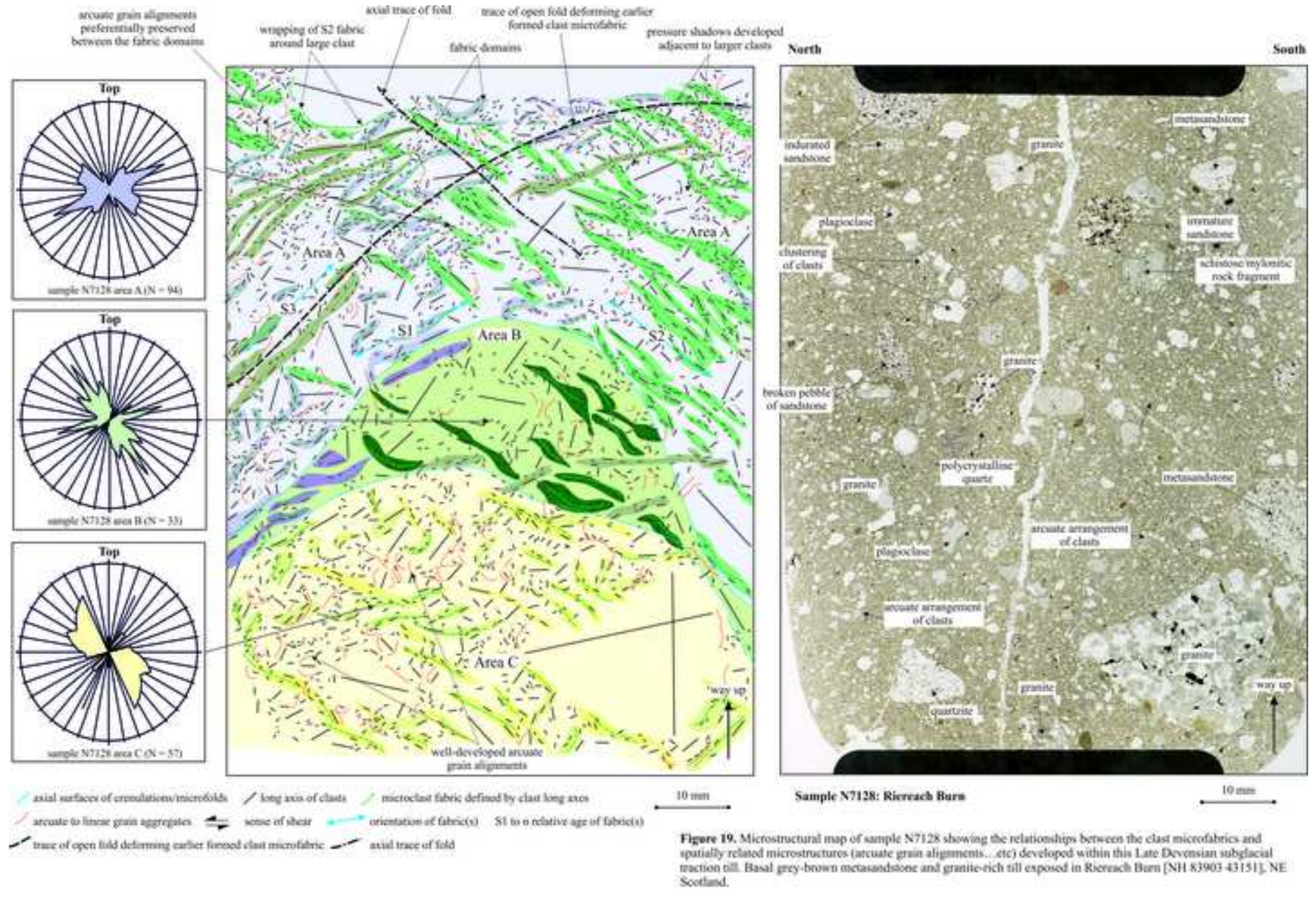

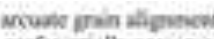

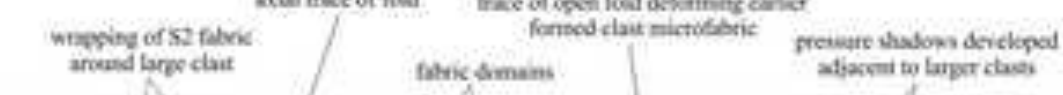

ath

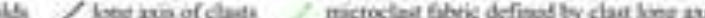

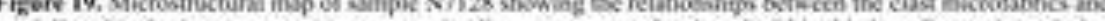
soctand.

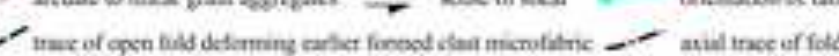




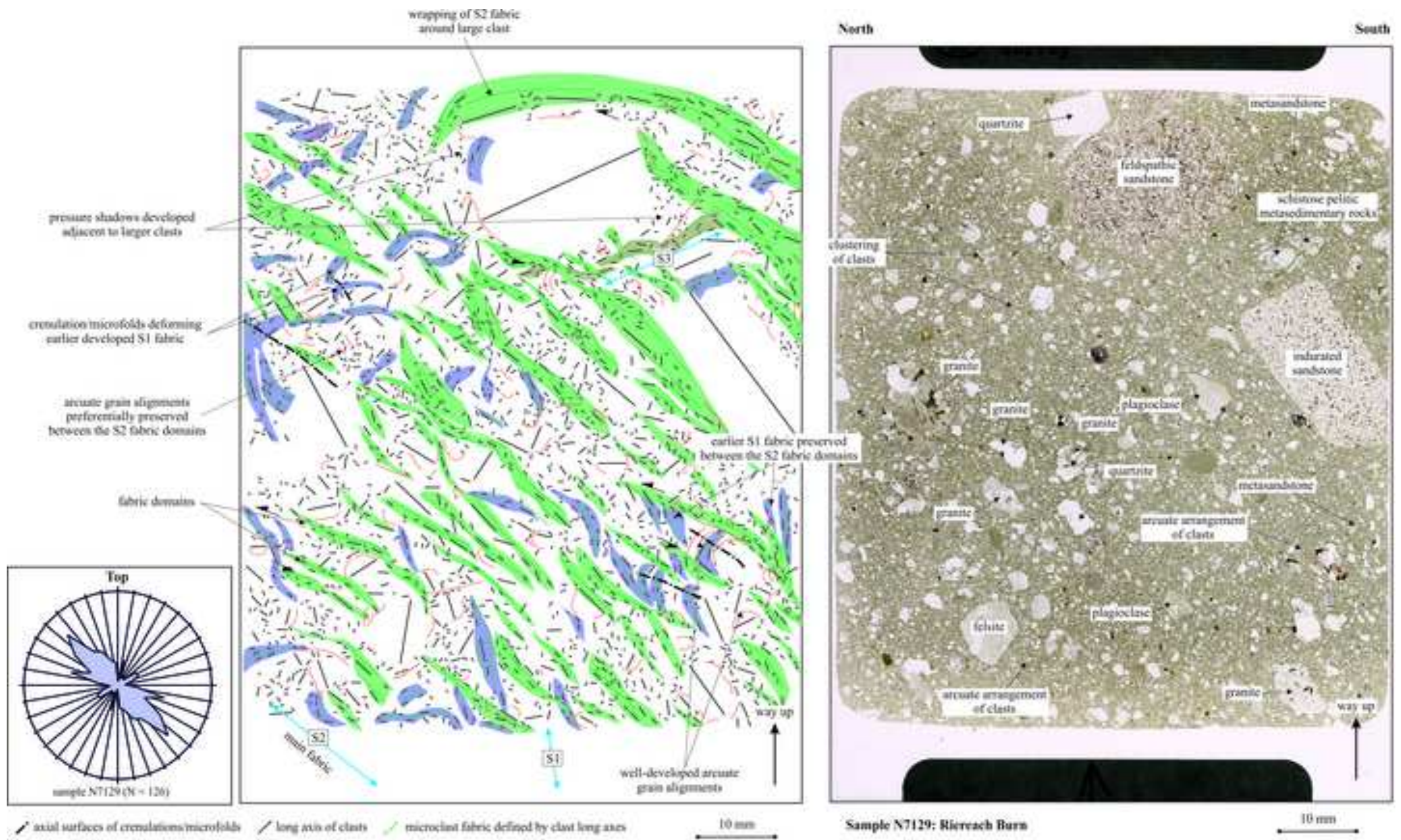

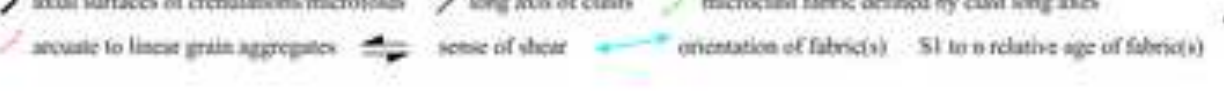

Figure 20. Microsinustuat mag of sample N7129 showing the relatimstips between the clast

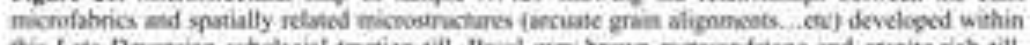

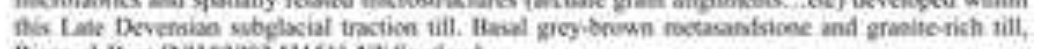

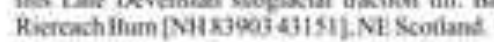


Click here to download high resolution image

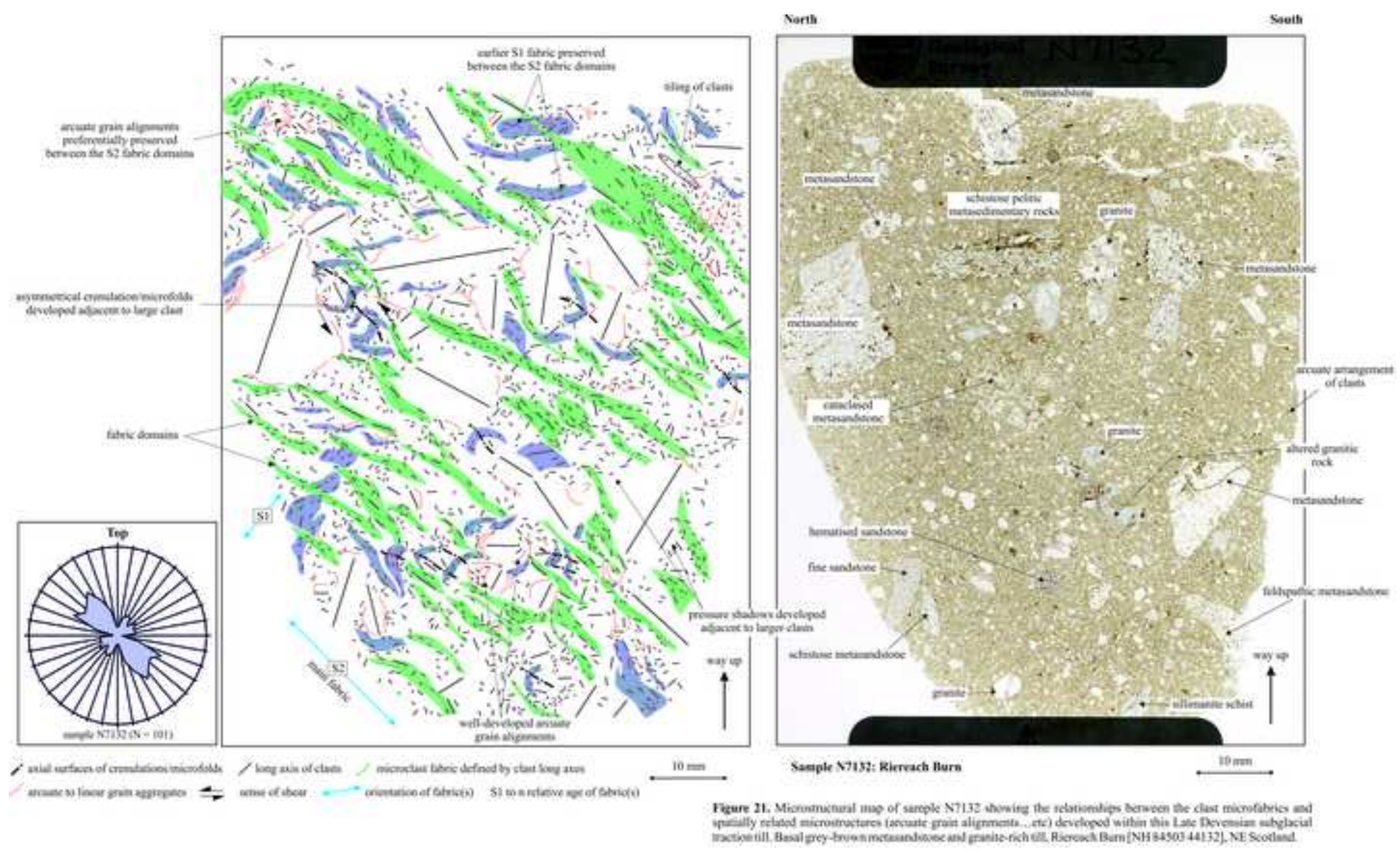




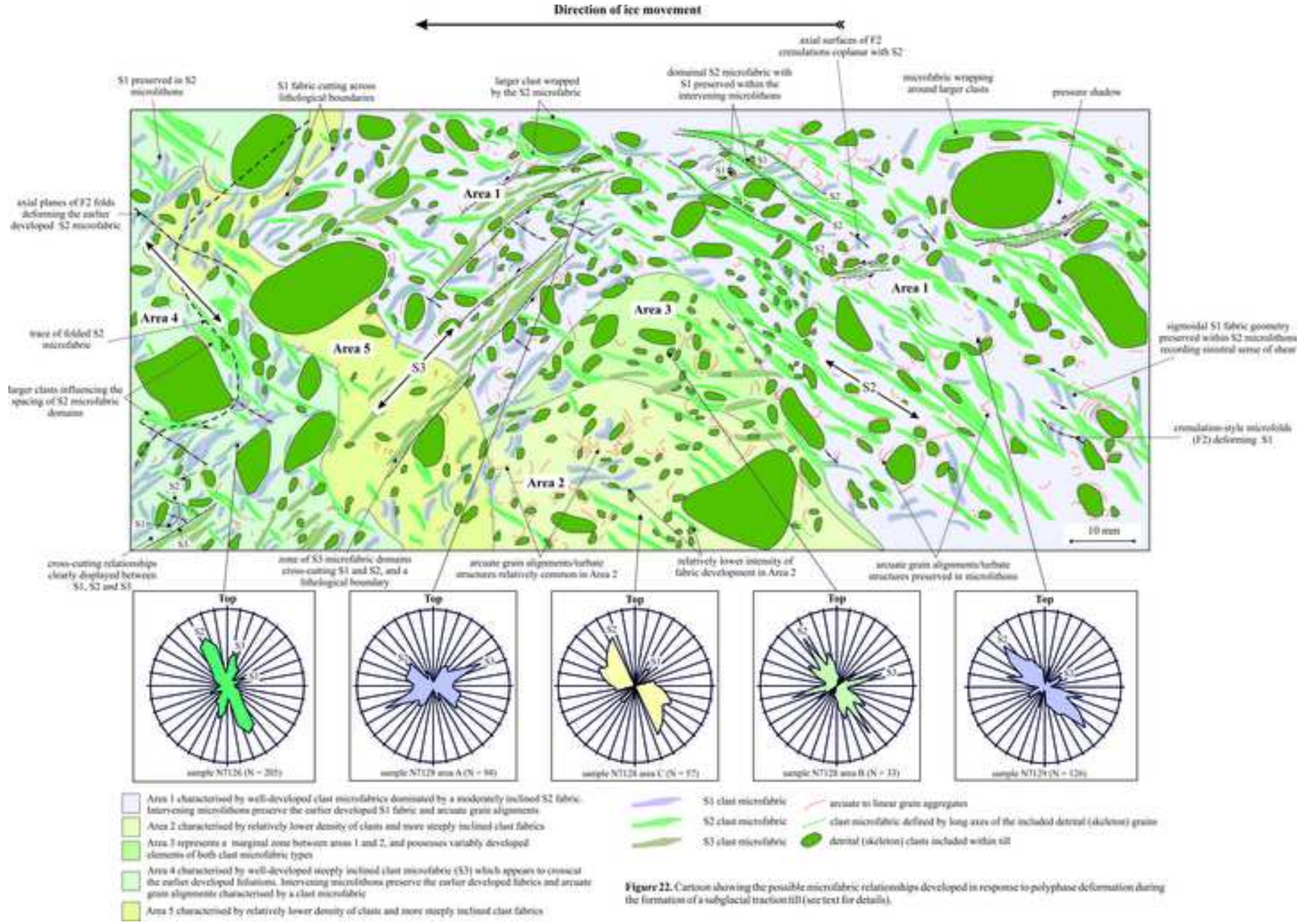

